\title{
Prdx1 deficiency in mice promotes tissue specific loss of heterozygosity mediated by deficiency in DNA repair and increased oxidative stress
}

\author{
by Vamsi K. Rani
}

\author{
A dissertation submitted to the \\ Graduate School-New Brunswick \\ Rutgers, The State University of New Jersey \\ And \\ The Graduate School of Biomedical Sciences \\ University of Medicine and Dentistry of New Jersey \\ In partial fulfillment of the requirements \\ For the degree of \\ Doctor of Philosophy \\ Graduate Program in \\ Microbiology and Molecular Genetics \\ Written under the direction of \\ Jay Tischfield \\ And approved by
}

New Brunswick, New Jersey

MAY, 2012 
(C) 2012

Vamsi K. Rani

ALL RIGHTS RESERVED 


\title{
ABSTRACT OF THE DISSERTATION \\ Prdx1 deficiency in mice promotes tissue specific loss of heterozygosity mediated by deficiency in DNA repair and increased oxidative stress
}

\author{
by VAMSI K. RANI \\ Dissertation director: \\ Professor Jay Tischfield
}

Loss of the $\mathrm{H}_{2} \mathrm{O}_{2}$ scavenger protein encoded by the peroxiredoxin 1 ( $\left.P r d x l\right)$ gene in mice leads to elevated intracellular amounts of reactive oxygen species (ROS) and promotes tumorigenesis in several different tissues. Loss of heterozygosity (LOH) mutations can initiate tumorigenesis through loss of tumor suppressor gene function in somatic cells that carry only one functional allele. A connection between the severity of oxidative stress and the frequency of LOH mutations has not been previously established in vivo. Therefore, in this study, we characterized in vivo $\mathrm{LOH}$ in ear fibroblasts and splenic T cells of 3-4 month old Prdx1-deficient mice. We found that loss of Prdx1 significantly elevates ROS levels in T cells and fibroblasts, and that basal levels of ROS are higher in fibroblasts than in T cells, probably due to a less robust Prdx1 peroxidase activity in the former. Using Aprt as a $\mathrm{LOH}$ reporter, we observed an elevation in $\mathrm{LOH}$ mutation frequency in fibroblasts, but not in T cells, of $\operatorname{Prdxl^{-/}}$ mice compared to $\operatorname{Prd} x 1^{+/+}$mice. The majority of the $\mathrm{LOH}$ mutations in both cell types were derived from mitotic recombination (MR) events. Interestingly, Mlh1, which is known to suppress MR 
between divergent sequences, was found to be significantly down-regulated in fibroblasts, but not in T cells, of $\operatorname{Prdx} 1^{-/}$mice. Additionally, there was no compensatory increase in expression of base excision repair (BER) genes in $\operatorname{Prdx1^{--}}$ fibroblasts. Since these cells had higher amounts of ROS, it suggests that BER activity may be insufficient to manage the increased oxidative DNA damage load. This could lead to increased formation of SSBs and DSBs, which could require repair by recombination. A combination of increased amounts of ROS, down-regulation of Mlhl and inefficient BER may have contributed to the elevation of MR in fibroblasts of $\operatorname{Prdx} 1^{-/}$mice. Additionally, my findings suggest that helix-distorting lesions may also be increased in $\operatorname{PrdxI^{--}}$ ear fibroblasts and T cells. Transcription analyses of genes in different DNA repair pathways in the whole spleen tissue with Prdx1 deficiency revealed significant differences in transcription compared to T cells. I conclude that mechanisms through which Prdx 1 deficiency promotes tumorigenesis in specific tissues may be distinct. 


\section{ACKNOWLEDGMENTS}

The successful completion of my $\mathrm{PhD}$ dissertation work would not be possible without the assistance of many different people. First of all, I have to thank Dr. Jay Tischfield for giving me the chance to join his lab and for being patient and supportive over the long road to this $\mathrm{PhD}$. There is no way that I could have completed this dissertation without the mentorship of Dr. Changshun Shao. He has helped me grow as a scientist and words cannot properly express my everlasting gratitude. I would like to thank Dr. Mark Brenneman for being the committee chair and Dr. Tony Kong for being supportive of the project and for serving on my committee. My sincere appreciation goes out to Dr. Carola Neumann for providing the Prdx 1 mice and for her support and valuable input in to this project. I would like to thank Jennifer Schulte in Dr. Neumann's lab for performing the Prdx1 western blot analyses.

I would also like to thank members of the Tischfield lab, past and present. First, I would like to thank Lily Deng for being a patient teacher of all of the techniques that were critical to the successful completion of this dissertation. I would like to thank Betty Zheng for help with the mouse tissue extraction among other things. I would also like to thank Dr. Natalia Denissova for all of the support and advice she has provided throughout the years, and I wish her good luck in her new position as Assistant Research Professor. I would also to thank Dr. Alejandro Nato for all of the conversations and his friendship throughout the years. My $\mathrm{PhD}$ experience would not have been as memorable without the students I have had the pleasure of mentoring: Christine Sedrak, Amogh Joshi, Ronik 
Patel and Monal Mehta. Finally, I would like to thank everyone else in the Tischfield lab that I had the pleasure of getting to know over the years.

Family and friends have been an integral part in the successful completion of my PhD. I would like to thank my dad, my step-mom, my little brother Yati, my older brother, my sister-in-law, and my beautiful niece. They have provided me with strength and support and I am very lucky and blessed to have them in my life. I would also like to thank Lara Desoto, for being a good friend and keeping me level headed with invaluable advice. Finally, I would like to also thank Jhansi Aunty who helped me get through the tough times especially after the death of my mom and has always provided words of encouragement. 


\title{
DEDICATION
}

\author{
To my Mom:
}

You will always be in my heart. 


\section{TABLE OF CONTENTS}

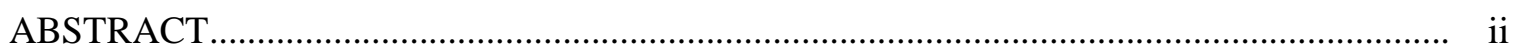

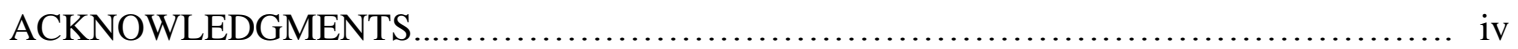

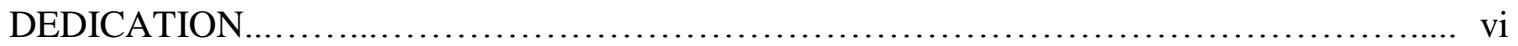

TABLE OF CONTENTS ................................................................ vii

Chapter One

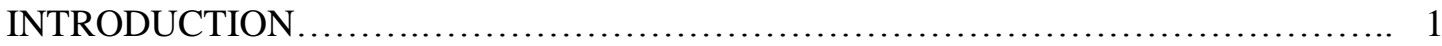

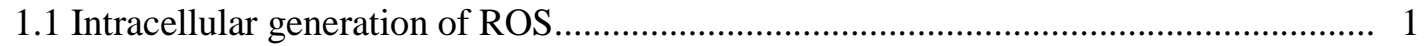

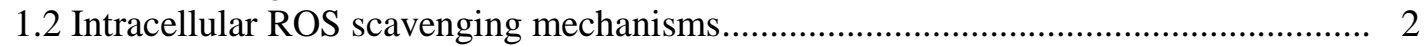

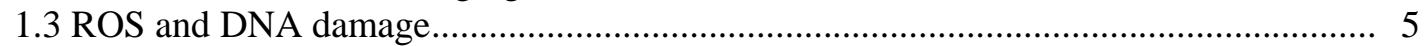

$1.4 \mathrm{LOH}$ and tumorigenesis..................................................... 10

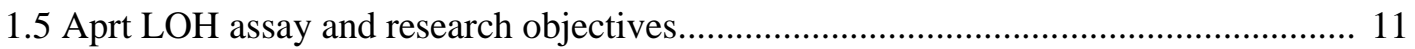

Chapter Two

ROLE OF PRDX1 IN MAINTENANCE OF HOMEOSTATIC AMOUNTS OF ROS...... 13

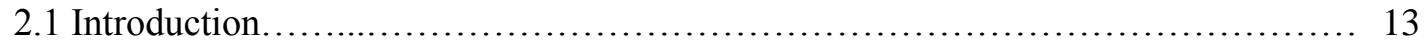

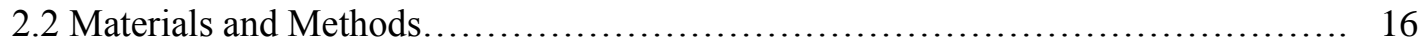

2.2.1 Mouse breeding.................................................... 16

2.2.2 Aprt and Prdx1 genotyping of Prdx1-Aprt mice............................ 17

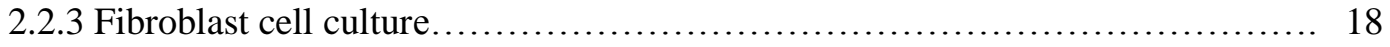

2.2.4 Splenic T cells isolation and culture ..................................... 19

2.2.5 ROS measurements in T-cells and ear fibroblasts.......................... 20

2.2.6 RNA extraction from primary fibroblasts and T-cells....................... 21

2.2.7 RNA extraction from whole spleen tissue................................ 22

2.2.8 Quantitative real-time PCR (qRT-PCR) ................................ 22

2.2.9 Western blot analyses of $\operatorname{Prdx} 1$ in $\mathrm{H}_{2} \mathrm{O}_{2}$ treated primary fibroblasts and T-cells... 24

2.2.10 Measurement of ROS amounts in cultured fibroblasts...................... 26

2.2.11 Cell survival analyses in cultured fibroblasts............................. 27

2.2.12 RNA expression analyses of $\mathrm{H}_{2} \mathrm{O}_{2}$ treated cultured ear fibroblasts............. 27

2.2 .13 Statistical Analyses................................................... 28

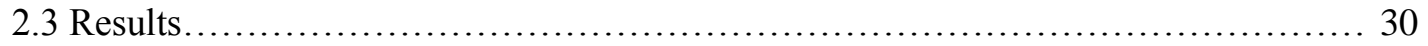

2.3.1 Increased ROS amounts in fibroblasts and T cells of $\operatorname{Prdx1^{-/}}$ mice............... 30

2.3.2 Transcriptional expression of antioxidant genes unaffected in $\operatorname{Prdx} I^{-/}$cells...... 33

2.3.3 Induction in expression of $\mathrm{H}_{2} \mathrm{O}_{2}$ scavenger genes in $\operatorname{Prdx} 1^{-/}$whole spleen tissue... 35

2.3.4 ROS amounts unaffected with $\operatorname{Prdx} 1$ loss after $\mathrm{H}_{2} \mathrm{O}_{2}$ treatment of fibroblasts...... 36 
2.3.5 Significant up-regulation of $\operatorname{Prdx} 6$ in $\mathrm{H}_{2} \mathrm{O}_{2}$ treated $\operatorname{Prdx} 1^{-/}$cultured fibroblasts... 36

2.3.6 Decreased cell survival with $\mathrm{H}_{2} \mathrm{O}_{2}$ treatment in $\operatorname{PrdxI^{-/}}$ fibroblasts............. 38

2.4 Discussion......................................................... 39

Chapter Three

TISSUE SPECIFIC EFFECT OF LOSS OF PRDX1 ON LOH MUTANT FREQUENCY 44

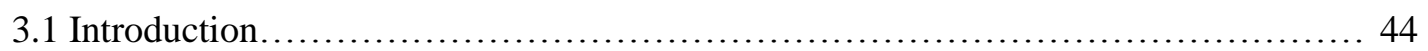

3.2 Materials and Methods............................................................ 46

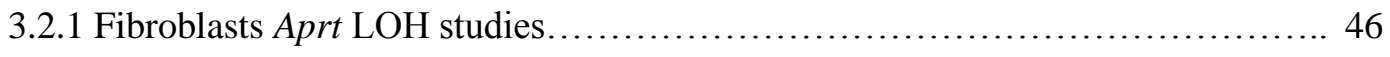

3.2.2 Splenic T cell Aprt LOH studies........................................... 46

3.2.3 CFE and DAP ${ }^{\mathrm{r}}$ frequency calculations................................... 48

3.2.4 DAP ${ }^{\mathrm{r}}$ frequency statistical analyses..................................... 49

3.2.5 Aprt mutant classification............................................ 50

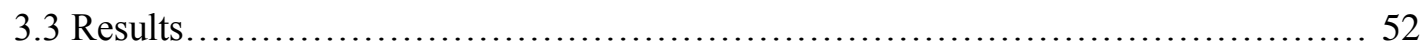

3.3.1 Increased LOH mutant frequency in ear fibroblasts of $\operatorname{Prdx} 1$ deficient mice...... 52

3.3.2 LOH mutant frequency in T cells unaffected with loss of $\operatorname{Prdx} 1 \ldots \ldots \ldots \ldots \ldots . \ldots 56$

3.4 Discussion.......................................................... 58

Chapter Four

THE EFFECT OF PRDX1 LOSS ON DNA REPAIR.................................. 61

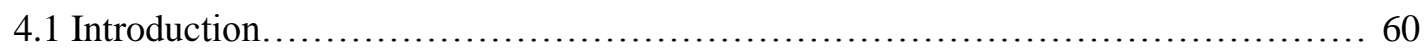

4.2 Materials and Methods........................................................... 65

4.2.1 Transcription analyses of DNA repair genes in T cells and primary fibroblasts.... 65

4.2.2 Transcription analyses of DNA repair genes in whole spleen tissue............ 66

4.2 .3 Statistical Analyses................................................. 66

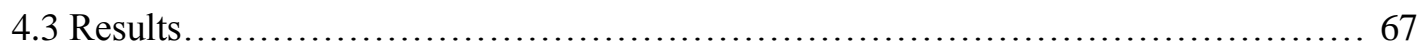

4.3.1 Expression of Mlh1 in $\operatorname{Prdx1} 1^{-/} \mathrm{T}$ cells and fibroblasts........................ 67

4.3.2 Base excision repair gene expression unaffected in $\operatorname{Prdx}{ }^{-/}$cells.................66 68

4.3.3 Induction of expression of long-patch BER genes in $\operatorname{Prdx} 1^{-}$spleen tissue........ 70

4.3.4 Down-regulation of Ercc1 in $\operatorname{Prdx}^{-/} \mathrm{T}$ cells and fibroblasts.................... 71

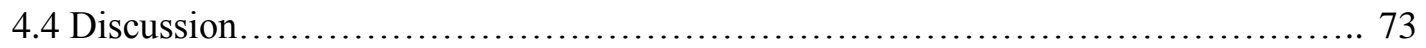

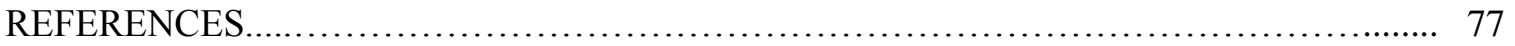

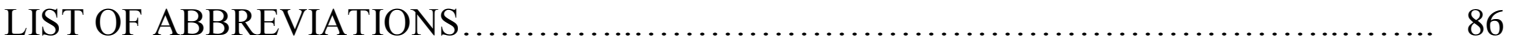

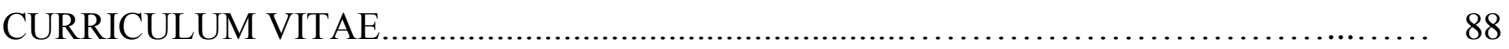




\section{Chapter 1. Introduction}

\subsection{Intracellular generation of ROS}

Reactive oxygen species (ROS), specifically superoxide $\left(\mathrm{O}_{2} \bullet^{-}\right)$radicals, are a natural by-product of various mammalian cellular metabolism processes. As illustrated in Figure 1.1, these processes include mitochondrial oxidative phosphorylation, nicotinamide adenine dinucleotide phosphate (NADPH) oxidase and cyclooxygenase metabolic reactions, among others. Oxidative phosphorylation consists of four distinct electron transport complexes, which make up the electron transport chain (Muller, 2000). $\mathrm{O}_{2}$ serves as the final electron acceptor for cytochrome-C oxidase, the final component of this complex, which involves the four-electron reduction of $\mathrm{O}_{2}$ to $\mathrm{H}_{2} \mathrm{O}$. However, in this process, partially reduced and highly reactive metabolites of $\mathrm{O}_{2}\left(\mathrm{O}_{2} \bullet\right)$ can be formed (Thannickal VJ \& Fanburg BL, 2000). On the other hand, NADPH oxidase catalyzes the production of superoxides from oxygen and NADPH (Equation 1) in both high and low amounts (Babior, 2004).

Equation 1. $\quad \mathrm{NADPH}+2 \mathrm{O}_{2} \rightarrow \mathrm{NADP}^{+}+\mathrm{H}^{+}+2 \mathrm{O}_{2}^{-}$

High amounts of superoxides are essential for phagocytosis and utilized by neutrophils, eosinophils, monocytes and macrophages. Low amounts of superoxides act as second messengers for cell signaling pathways related to cell growth, apoptosis and extracellular matrix (ECM) remodeling (Babior, 2004). Cyclooxygenase (COX) converts arachidonic acid to hydroperoxy endoperoxide prostaglandin $\mathrm{G}_{2}\left(\mathrm{PGG}_{2}\right)$ and reduces $\mathrm{PGG}_{2}$ to $\mathrm{PGH}_{2}$ 
using NADPH as a co-substrate which results in a radical NADP- molecule that can interact with $\mathrm{O}_{2}$ to form $\mathrm{O}_{2}$ radicals (Kukreja $\mathrm{RC}$ et al., 1986).

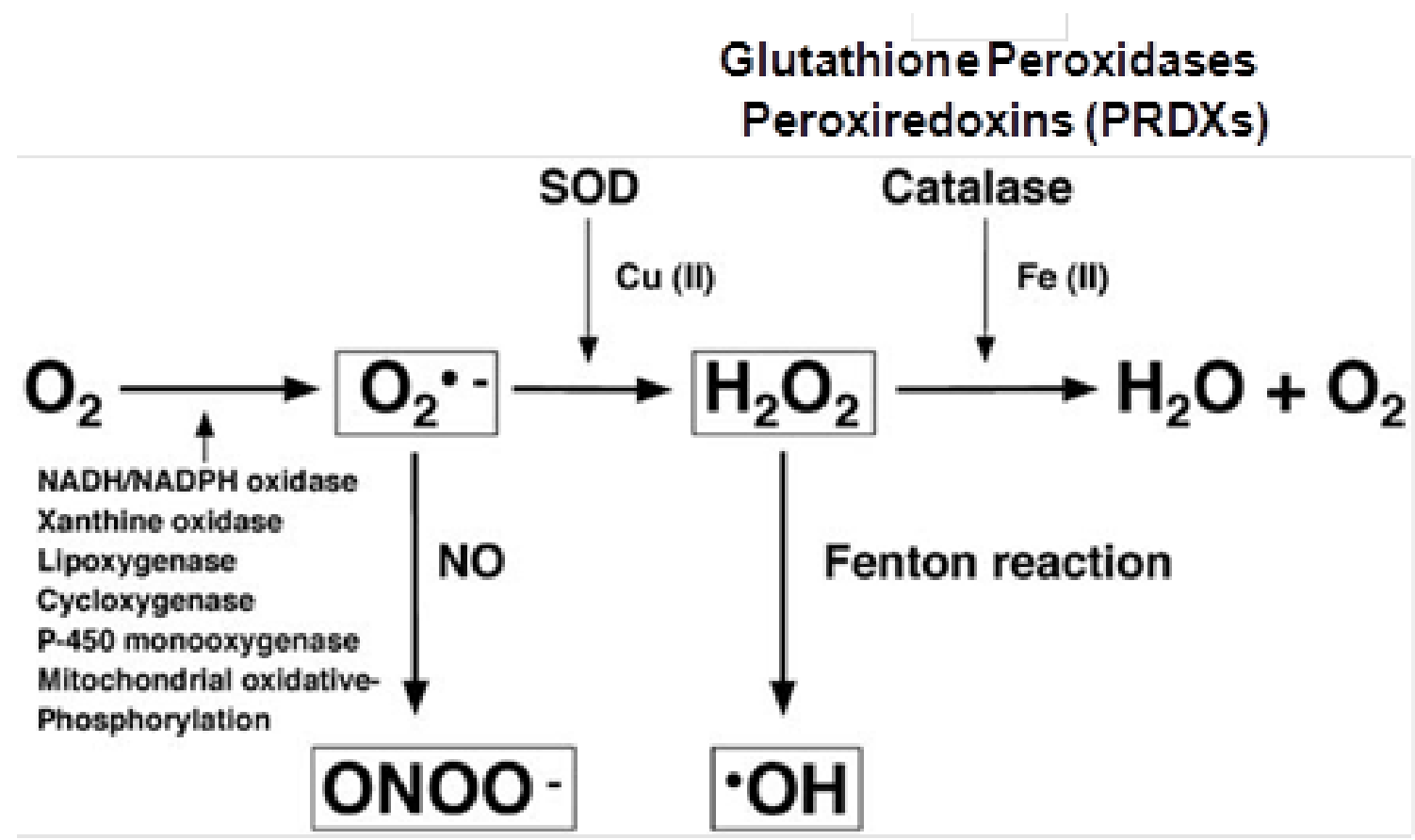

Figure 1.1. Sources of endogenous ROS and formation of different types of free radicals (adapted from Yoshizumi et al., 2001).

All of these enzymatic processes contribute in different manners to the overall production of superoxide radicals $\left(\mathrm{O}_{2} \bullet\right)$. Superoxide radicals are either dismutated to hydrogen peroxide $\left(\mathrm{H}_{2} \mathrm{O}_{2}\right)$ or converted to peroxynitrite radicals $\left(\mathrm{ONOO}^{-}\right)$through an interaction with nitric oxide (NO).

\subsection{Intracellular ROS scavenging mechanisms}

There are 3 types of superoxide dismutase (SOD) enzymes responsible for the dismutation of $\mathrm{O}_{2} \bullet$ radicals: manganese $(\mathrm{Mn}) \mathrm{SOD}$, copper-zinc $(\mathrm{CuZn}) \mathrm{SOD}$ and extracellular (EC)-SOD. MnSOD functions primarily in the mitochondria, CuZnSOD in the cytosol, and EC-SOD in the extracellular matrix (Elchuri S et al., 2005). Their 
dismutation rate constants are similar $\left(\sim 1.6 \times 10^{9} \mathrm{M}^{-1} \mathrm{sec}^{-1}\right)$ and the balanced reaction is depicted in Equation 2.

Equation 2. $2 \mathrm{O}_{2}^{-}+2 \mathrm{H}^{+} \rightarrow+\mathrm{H}_{2} \mathrm{O}_{2}+\mathrm{O}_{2}$

$\mathrm{H}_{2} \mathrm{O}_{2}$ can then either be scavenged to $\mathrm{H}_{2} \mathrm{O}$ and $\mathrm{O}_{2}$ or converted to hydroxyl radicals $(\mathrm{OH} \bullet)$ through the Fenton reaction.

$\mathrm{H}_{2} \mathrm{O}_{2}$ is converted to $\mathrm{H}_{2} \mathrm{O}$ and $\mathrm{O}_{2}$ by different families of peroxidases: catalase, glutathione peroxidases (GPXs) and peroxiredoxins (PRDXs). GPXs are expressed in all sub-cellular compartments as well as in the extracellular matrix and they scavenge low amounts of $\mathrm{H}_{2} \mathrm{O}_{2}$. Gpx1 is the primary cytosolic glutathione peroxidase and is ubiquitously expressed in mice. As depicted in Figure 1.2, Gpx1 contains a selenocysteine residue (-SeH) that is oxidized by $\mathrm{H}_{2} \mathrm{O}_{2}$. The oxidized Gpx1 is inactive and must be reduced back to its active state (-SeH) by glutathione (GSH) (Veal E et al., 2007). Catalase functions primarily in peroxisomes and uses a heme prosthetic group to reduce $\mathrm{H}_{2} \mathrm{O}_{2}$ with a catalytic efficiency of $\sim 10^{6} \mathrm{M}^{-1} \mathrm{~s}^{-1}$ (Hillar A et al., 2000) and an affinity for $\mathrm{H}_{2} \mathrm{O}_{2}\left(\mathrm{~K}_{\mathrm{m}}\right)$ of $10^{3}-10^{5} \mu \mathrm{M}$ (D'Autreaux B \& Toledano M, 2007). Peroxiredoxins (PRDXs) have a greater affinity $\left(\mathrm{Km}=1-10^{3} \mu \mathrm{M}\right)$ for $\mathrm{H}_{2} \mathrm{O}_{2}$ but have a lower catalytic constant, thus having a lower catalytic efficiency $\left(10^{5} \mathrm{M}^{-1} \mathrm{~s}^{-1}\right)$ compared to GPXs and catalase. At low amounts of $\mathrm{H}_{2} \mathrm{O}_{2}$, PRDXs and GPXs are responsible for $\mathrm{H}_{2} \mathrm{O}_{2}$ scavenging, while catalase is primarily responsible for scavenging high amounts of $\mathrm{H}_{2} \mathrm{O}_{2}$. The poor catalytic efficiency of PRDXs is primarily due to the over-oxidation of the redox active cysteine sulfhydryl sites of typical 2-Cys PRDXs (Prdxs 1-4, Figure 1.3). 
Prdx 1 is an obligate homodimer that requires formation of a disulfide bridge between the redox active cysteine that is oxidized to sulfinic acid $\left(\mathrm{Cys}^{51}-\mathrm{SOH}\right)$ and the resolving cysteine $\left(\mathrm{Cys}^{172}-\mathrm{SH}\right)$ in order to decompose $\mathrm{H}_{2} \mathrm{O}_{2}$. However, the slow kinetics of the disulfide bridge formation allows for over-oxidation of $\mathrm{Cys}^{51}$-SOH to sulfonic acid $\left(\mathrm{Cys}^{51}-\mathrm{SO}_{2} \mathrm{H}\right)$. This traps the protein as an oxidized monomer that cannot form a disulfide bridge with the resolving cysteine $\left(\mathrm{Cys}^{172}\right.$-SH) (Wagner E et al., 2002; Wood ZA et al., 2003), which leads to inactivation of its peroxidase activity.

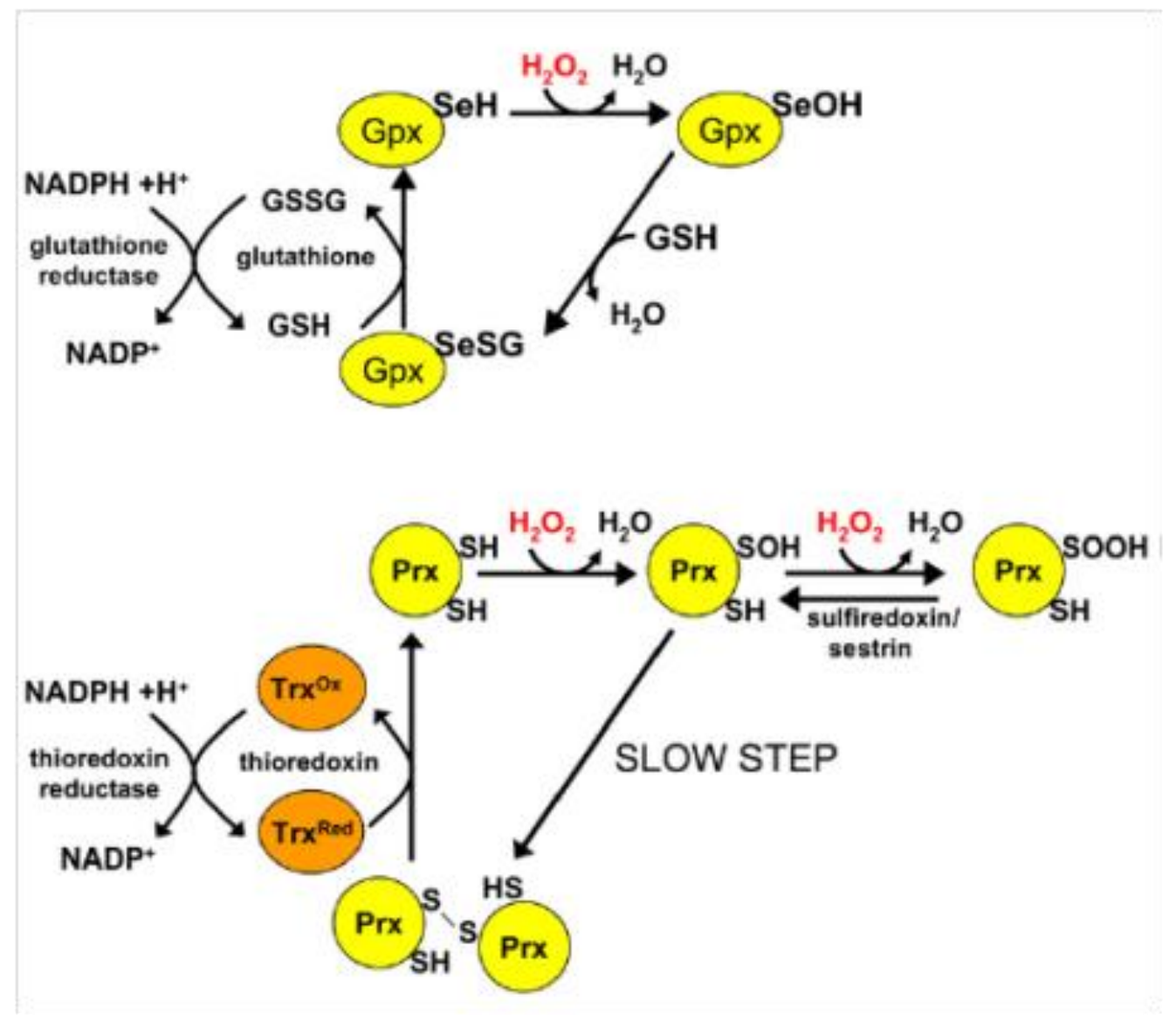

Figure 1.2. The redox-cycling catalytic removal of $\mathrm{H}_{2} \mathrm{O}_{2}$ by the glutathione peroxidase and the peroxiredoxin systems (Adapted from Veal EA et al., 2007). 

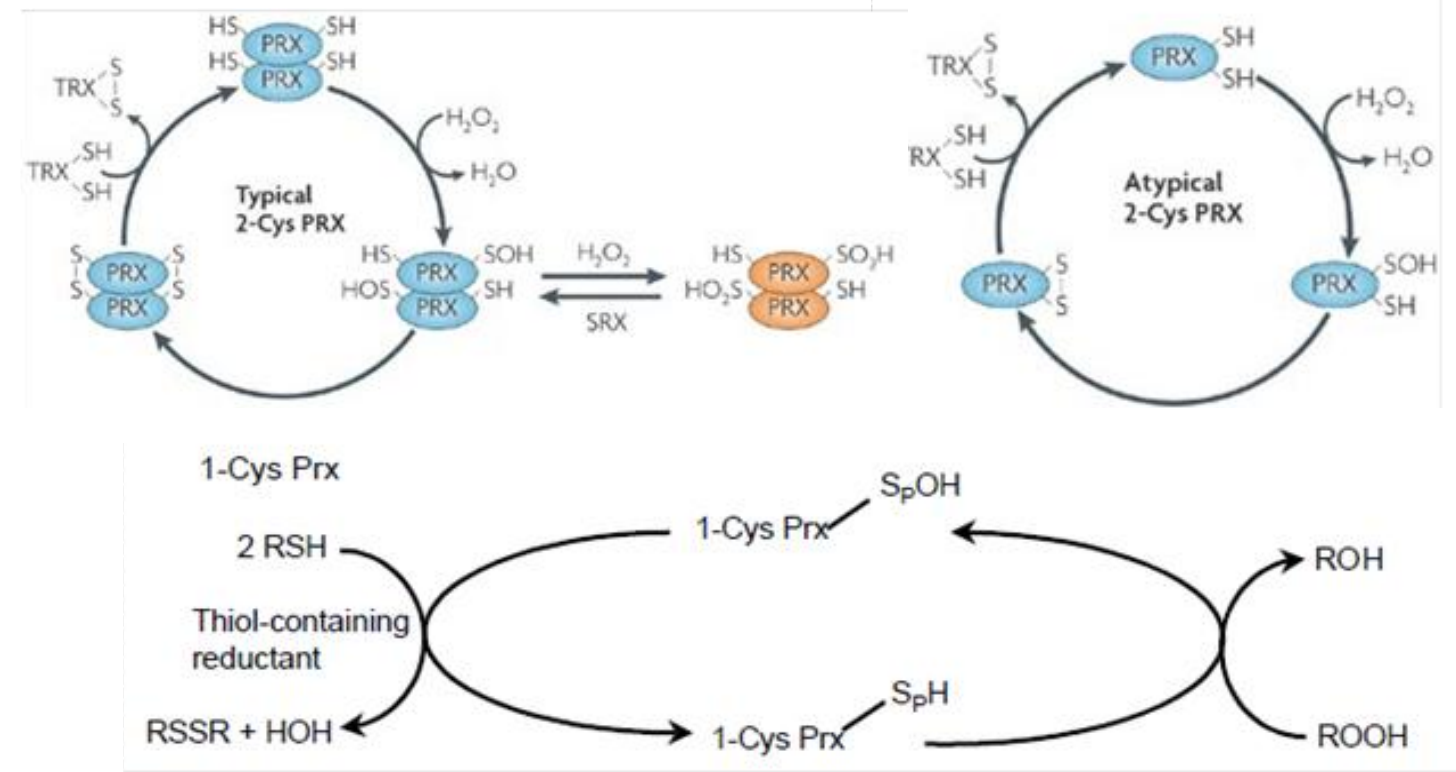

Figure 1.3. Mechanism of reduction of $\mathrm{H}_{2} \mathrm{O}_{2}$ by Prdxs and over-oxidation of typical 2Cys Prdxs (adapted from D'Autreaux B \& Toledano M, 2007 and Wood ZA et al., 2003).

However, $\mathrm{Cys}^{51}-\mathrm{SO}_{2} \mathrm{H}$ can be reduced by the oxidoreductase sulfiredoxin (SRX in Figure 1.3) (Jeong W et al., 2006) to sulfinic acid, which can then form the disulfide bridge with the resolving cysteine. Prdx5, the atypical 2-Cys peroxiredoxin ( $P r d x)$ reduces $\mathrm{H}_{2} \mathrm{O}_{2}$ in the same way as the 2-Cys PRDXs, but is a monomer and has the resolving and the redox active cysteines on the same polypeptide. Therefore, the cysteines do not become overoxidized, but do have to be reduced by thioredoxin. Prdx6 is a 1-Cys PRDX where only a redox-active cysteine sulfhydryl group is oxidized by $\mathrm{H}_{2} \mathrm{O}_{2}$ and is then reduced by a thiol-containing reductant after it has been oxidized (Wood ZA et al., 2003). Hydrogen peroxide, through the Fenton reaction, can also be converted to hydroxyl radicals $(\mathrm{OH} \bullet)$ (Valko M et al., 2007), which are highly reactive with DNA but have an in vivo half-life of only $10^{-9} \mathrm{~s}$ (Pastor $\mathrm{N}$ et al., 2000). Maintenance of homeostatic amounts of ROS by 
limiting the production of highly reactive oxygen radicals (e.g. ONOO- and $\mathrm{OH} \bullet$ ) minimizes damage to DNA and other macromolecules.

\subsection{ROS and DNA damage}

Oxidation of lipids, proteins and DNA leads to damage of the macromolecule occurs through their interaction with highly reactive oxygen radicals. The focus of this work will be on oxidative DNA damage. ROS is known to cause at least 100 different types of DNA damage including base modifications (e.g. 8-oxoG, thymidine glycol \& 8hydroxycytosine), single strand breaks (SSBs), double strand breaks (DSBs) and interstrand cross-links (Cadet $\mathrm{J}$ et al., 1997). The hydroxyl $(\mathrm{OH} \bullet)$ radical is especially reactive and can damage purine and pyrimidine bases and also the deoxyribose backbone when they originate near DNA (Dizdaroglu M et al., 2002). It reacts with DNA by addition of double bonds to DNA bases and by abstraction of an $\mathrm{H}$ atom from the methyl group of thymine and each of the C-H bonds of 2'-deoxyribose (Sonntag V, 1987). Important biomarkers of oxidative stress include 8-oxo-guanine (8-oxoG) and thymine glycol. The low redox potential of guanine makes it especially vulnerable to oxidation. Oxidation of guanine at C8 (Figure 1.4A) converts a hydrogen bond acceptor (N7) to a hydrogen bond donor, allowing a stable mismatch base pair to form between 8-oxoG and adenine (Figure 1.4B) (Hsu GW et al., 2004). Estimated steady state levels of 8-oxoG is about $10^{3}$ per cell/per day (Lindahl T \& Barnes DE, 2000). These types of lesions are repaired by base excision repair (BER). Base excision repair involves recognition of the lesion, removal of the lesion, nucleotide synthesis with polymerases and ligation of the single strand. This repair mechanism will be described in much greater detail in Chapter

3. However, if the lesions are not repaired before replication, they can lead to G:C $\rightarrow \mathrm{T}: \mathrm{A}$ 
transversions. For example, $\mathrm{H}_{2} \mathrm{O}_{2}$ treatment of human T-lymphocytes led to increased Hprt mutant frequency with a majority of mutations classified as transitions at GC base pairs (Llera-Diaz S et al., 2000).
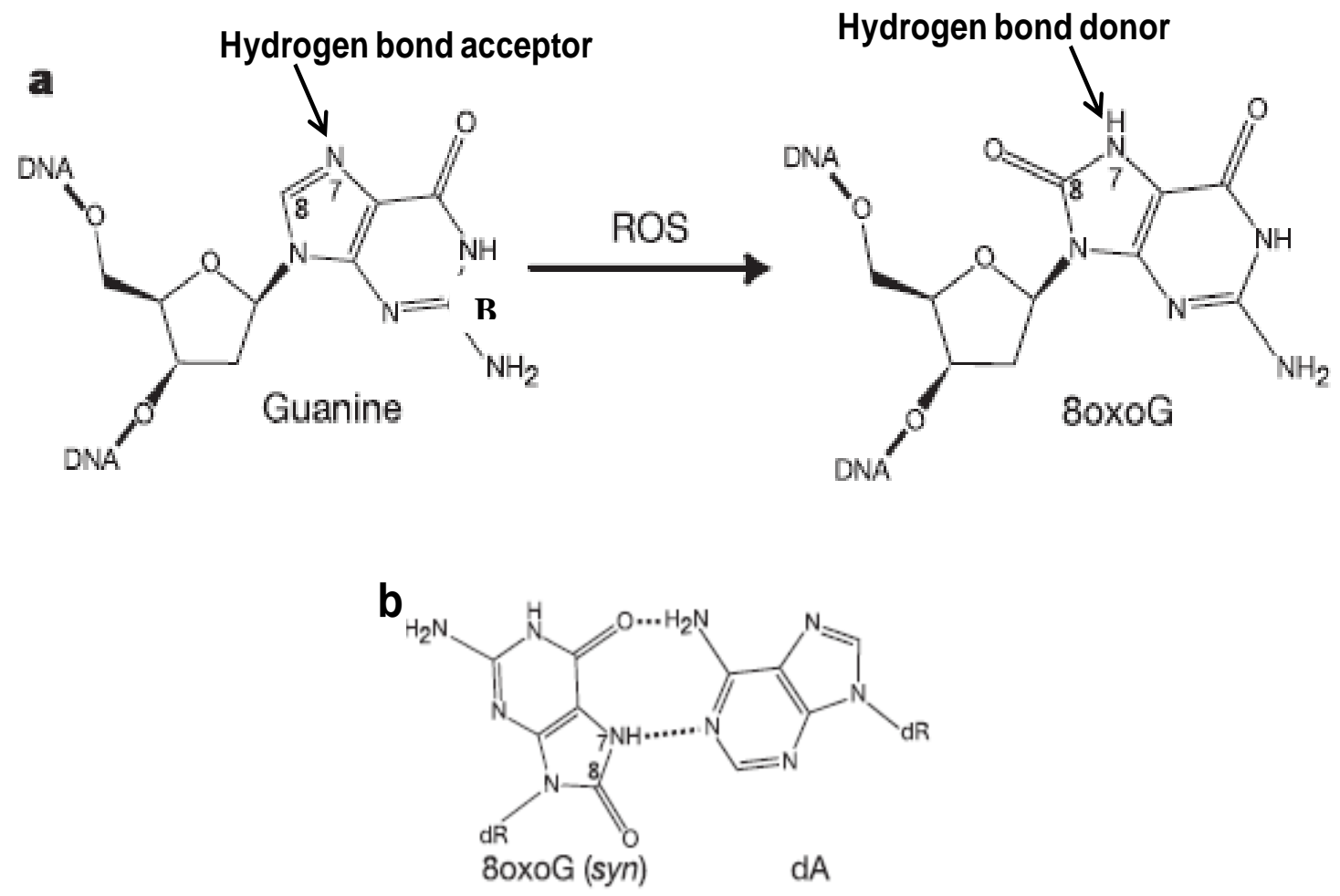

Figure 1.4 A. Oxidation of guanine at C8 by ROS B. Mismatch pairing with adenine (Adapted from Hsu GW et al., 2004).

Additionally, oxidative DNA damage could stem from compromised ROS scavenging, as in the case of $\operatorname{Prdx} 1^{-/}$mouse embryonic fibroblasts (MEFs) that exhibited increased amounts of ROS compared to $\operatorname{Prdx1^{+/+}}$ MEFs and an elevated number of 8-oxo-guanine (8-oxoG) DNA lesions (Neumann C et al., 2003). A separate study involving adult $\operatorname{Prd} x 1^{-/}$mice found increased amounts of different types of oxidative DNA lesions in primary cells derived from the brain, the spleen and the liver (Egler et al., 2005). The effect consequences of oxidative DNA lesions in tumorigenesis have been validated in 
humans as G:C $\rightarrow$ T:A transversions were found in the Ras oncogene and the p53 tumor suppressor gene in lung and liver cancer (Cooke M et al., 2003).

In addition to base modifications, 8,5 'cyclopurine-2'deoxynucleosides can also occur as a consequence of attack by ROS. As illustrated in Figure 1.5, these lesions are formed by the initial $\mathrm{OH} \bullet$ radical attack at $\mathrm{C}^{2}$ ' by hydrogen abstraction followed by an attack on the $\mathrm{C} 5$ ' centered radical at $\mathrm{C} 8$ leading to $\mathrm{C} 5$ '-C8 cyclization (Jaruga $\mathrm{P}$ and Dizdaroglu, 2008). The attack of the C5' -centered radical at C8 requires the base to rotate around the glycosidic bond to bring $\mathrm{C} 5$ ' and $\mathrm{C} 8$ close enough to form the $\mathrm{C} 5$ ' $-\mathrm{C} 8$ covalent bond. In DNA, the C5'-C8-cyclization requires large changes in backbone torsion angles, resulting in weakening Watson-Crick hydrogen bonds and substantial perturbations of the DNA double helix near the lesion (Miaskiewicz K et al., 1995). Due to the distortions in the DNA, these lesions, if not properly repaired, can block or reduce transcription (Brooks PJ et al., 2000; Marietta C et al., 2002). A significant increase in the number of helix distorting lesions was evidenced in different tissues of $\operatorname{Prdx} \mathrm{I}^{-/}$mice as measured by liquid chromatography/mass spectrometry (LC-MS) analysis. However, this was not always directly correlated with increased ROS amounts (Egler RA et al., 2005). Therefore, it was hypothesized to be due to defective nucleotide excision repair (NER), which is the primary repair mechanism of helix distorting lesions. Defective NER is also important in the promotion of certain human cancers, particularly skin cancers associated with the familial syndrome xeroderma pigmentosum (XP) (Friedberg EC et al., 2005). NER involves the recognition of the helix distortion lesions, which subsequently leads to the removal of a short single-stranded DNA segment that includes the lesion, creating a single-strand gap in the DNA. 


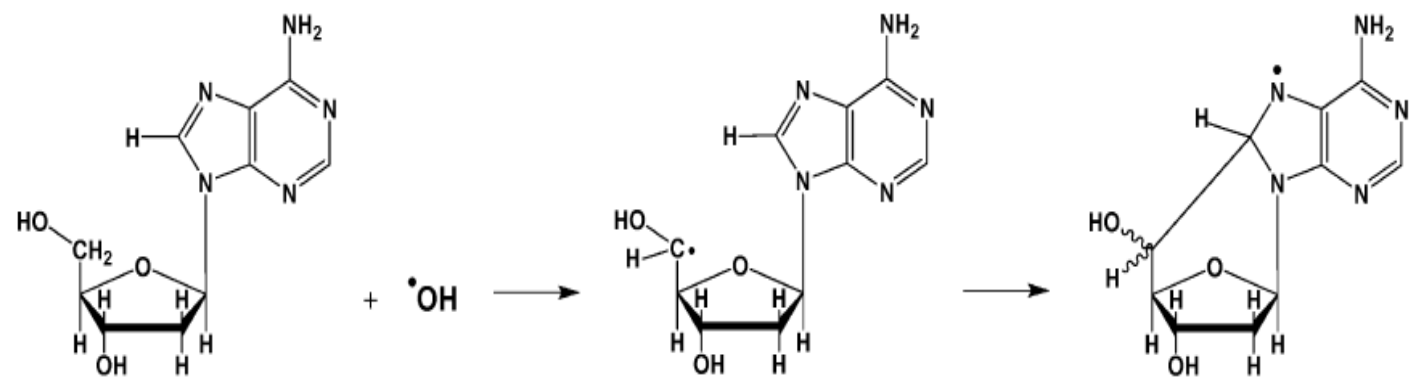

2'-deoxyadenosine

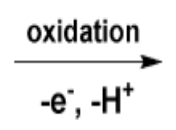

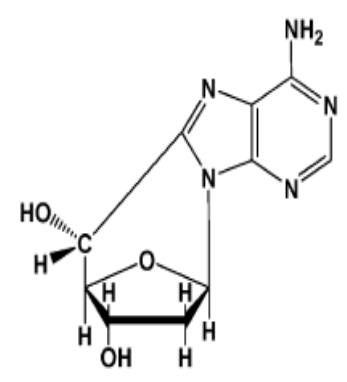

(5'R)-8,5'-cyclo-2'-deoxyadenosine

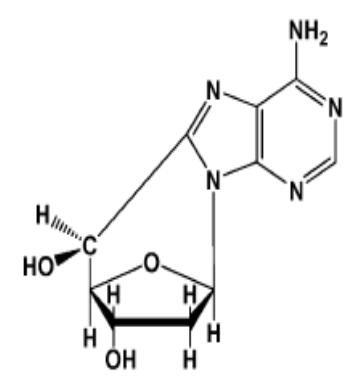

(5'S)-8,5'-cyclo-2'-deoxyadenosine

Figure 1.5. Mechanism of formation of 8,5' cyclopurine-2' deoxynucleosides (Jaruga $P$ and Dizdaroglu, 2008).

The gap is then filled in by DNA polymerase, which uses the undamaged strand as a template. NER can be divided in to two sub-pathways, global-genomic NER and transcription-coupled NER that differ only in their recognition of helix-distorting DNA damage. This repair mechanism is explained in greater detail in Chapter 3.

Accumulation of highly reactive $\mathrm{ROS}\left(\right.$ e.g. $\mathrm{OH} \bullet$ and $\mathrm{ONOO}^{-}$) also leads to increased formation of single strand breaks (SSBs) (Cantoni M et al., 1989; Ward JF et al., 1985; Hoffman ME et al., 1984). Furthermore, elevated amounts of ROS could promote formation of double strand breaks (DSBs) as observed when cells were treated with high dosages of $\mathrm{H}_{2} \mathrm{O}_{2}$ (Prise KM et al., 1989; Dahm-Daphi J, 2000). This can occur 
either as a result of the formation of another SSB on the complementary strand of DNA or as the consequence of the advancing replication complex at the site of the original SSB, which leads to replication stalling. Repair of DSBs could happen either by homologous recombination (HR) or non-homologous end-joining (NHEJ). A consequence of repairing DSBs is loss of heterozygosity $(\mathrm{LOH})$ at a locus that is normally heterozygous in somatic cells. Treatment in vitro with $\mathrm{H}_{2} \mathrm{O}_{2}$ on different cell types has led to increased frequency of $\mathrm{LOH}$ mutations that were primarily derived from mitotic recombination (MR), a type of HR (Turker et al., 1999; Turner et al., 2003).

\subsection{LOH and Tumorigenesis}

Loss of heterozygosity $(\mathrm{LOH})$ is one of the rate-limiting steps in tumorigenesis when it leads to loss of function of a tumor suppressor gene (TSG). Certain human cancers like retinoblastoma, Wilms tumor or tumors associated with Li-Fraumeni syndrome originate due to loss of function for the tumor suppressor genes retinoblastoma 1 (RB1), Wilms tumor 1 (WT1) or TP53, respectively (Knudson AG, 1993). These tumors arise from two separate mutational hits; a first mutational hit that occurs early in development or is inherited from one of the parents, followed by a second mutational hit occurring later during somatic cell division in a susceptible tissue. Loss of heterozygosity ( $\mathrm{LOH})$ of a tumor suppressor gene can be an early step in tumorigenesis. For example, mutation of one allele of the adenomatous polyposis coli (APC) gene and the subsequent mutation of the other allele are amongst the first observed genetic alterations in sporadic intestinal tumors (Fearon ER \& Vogelstein B, 1990). This indicates that LOH occurs in normal somatic cells, and can contribute to neoplastic 
transformation. Therefore, measurement of the frequency of in vivo LOH mutations in somatic cells under different conditions (e.g. DNA repair deficiency, irradiation) is important in understanding its role in cancer predisposition. Two different mouse models, adenine phosphoribosyltransferase (Aprt) and thymidine kinase (Tk) heterozygous mice have been used to study $\mathrm{LOH}$.

\subsection{Aprt LOH assay and research objectives}

The Aprt gene is located on the telomeric end of mouse chromosome 8 and is responsible for the formation of AMP and inorganic pyrophosphate from adenine and 5phosphoribosyl-1-pyrophosphate (PRPP). It also produces adenine as a by-product of the polyamine biosynthesis pathway. Aprt ${ }^{+/-}$cells grown in medium containing 2,6diaminopurine (DAP) produce an adenine analog that is incorporated in to the DNA and is toxic to the cells. Therefore, cells that have undergone in vivo loss of heterozygosity (LOH) that includes Aprt are recovered as cell colonies in vitro by virtue of their resistance to 2,6-diaminopurine (DAP) (Shao C et al., 2004). The recovered colonies can then be analyzed to determine the mutational mechanism that produced the in vivo LOH. Multi-locus events such as mitotic recombination (MR), deletion and chromosomal loss with and without duplication can be responsible for LOH. Chromosomal loss could occur as a consequence of mitotic non-disjunction due to improper chromosome segregation during mitosis (Wijnhoven SWP et al., 2001). Locus restricted events such as gene conversion, base-pair modifications (e.g. deletion, substitution) and epigenetic inactivation could also be responsible for $\mathrm{LOH}$. 
Although the direct correlation between the amount of ROS formation and frequency of LOH mutations has been previously demonstrated in vitro (Turker et al., 1999; Turner et al., 2003), no study has focused on the in vivo connection between changes in amounts of reactive oxygen species (ROS) and the frequency of in vivo LOH mutations. LOH is frequently a rate-limiting step in tumorigenesis (Knudson, 1971) and increased frequency of $\mathrm{LOH}$ mutations is positively correlated with increased cancer incidence such as that which is observed in Prdx1-deficient mice (Neumann et al., 2003). Hence, the objective of this study was to determine whether changes in the amounts of ROS in vivo is directly correlated to changes in LOH mutant frequency in vivo, by measuring the spontaneous Aprt LOH mutant frequencies in ear fibroblasts and splenic $\mathrm{T}$ cells of Prdx1-deficient mice. A secondary objective was to determine whether the tissue-specific differences in ROS amounts were due to differences in Prdx1 peroxidase activity. Finally, we aimed to determine whether any changes in the intracellular amounts of ROS and the frequency of LOH mutations that might exist in each tissue type could be due to altered expression of genes that encode antioxidant proteins and DNA repair proteins, respectively. 


\section{Chapter 2}

\section{ROLE OF PRDX1 IN THE MAINTENANCE OF HOMEOSTATIC AMOUNTS OF ROS}

\subsection{Introduction}

The sequential expression of antioxidant genes in different cellular compartments maintains homeostatic amounts of ROS that ensures minimal formation of highly reactive oxygen radicals (e.g. $\mathrm{OH} \bullet$ and $\mathrm{ONOO}^{-}$) that can damage various macromolecules. For example, the loss of copper-zinc superoxide dismutase (Sod1) enzyme in mice led to an intracellular accumulation of highly reactive peroxynitrite radicals $\left(\mathrm{ONOO}^{-}\right)$as a byproduct of the interaction of superoxide radicals $\left(\mathrm{O}_{2} \bullet\right)$ with nitric oxide (Muller FL et al., 2006; Busuttil RA et al., 2005; Elchuri S et al., 2005). On the other hand, the overexpression of Sod1 led to an increased formation of hydroxyl radicals $(\mathrm{OH} \bullet)$ (Karanjawala ZE et al., 2002). This probably occurred as the consequence of an excessive dismutation to $\mathrm{H}_{2} \mathrm{O}_{2}$ that was not properly reduced to $\mathrm{H}_{2} \mathrm{O}$ and $\mathrm{O}_{2}$, which allows for greater conversion of $\mathrm{H}_{2} \mathrm{O}_{2}$ to $\mathrm{OH} \bullet$ through the Fenton reaction. This could also occur as a result of compromised $\mathrm{H}_{2} \mathrm{O}_{2}$ scavenging as observed in $G p x 1^{-/-}$cells that were treated with $\mathrm{H}_{2} \mathrm{O}_{2}$ (de Haan JB, 1998). Surprisingly, the loss of catalase functionality in mice seemed to have an insignificant effect on amounts of ROS even after exposure to oxidative stressors (Ho YS et al., 2004). However, peroxiredoxins (PRDXs) are expressed in all sub-cellular compartments and are shown to be crucial in the maintenance of homeostatic amounts of ROS. For example, the loss of Prdx6 in mouse macrophages led to significantly higher basal amounts of ROS. This elevation in ROS amounts was further enhanced after treatment of $\operatorname{Prdx} 6^{-/-}$macrophages with 
different stressors (paraquat, $\mathrm{H}_{2} \mathrm{O}_{2}$ and tert-butyl hydroperoxide) in comparison to $\operatorname{Prdx}^{+/+}$macrophages (Wang $\mathrm{X}$ et al., 2003). They also found that in treated $\operatorname{Prdx\sigma ^{-/}}$ macrophages that there was no compensation in transcriptional expression of SODs, other PRDXs, glutathione peroxidases (GPXs) and catalase. Prdx1 and Prdx2 are the most ubiquitously expressed PRDXs and the loss of either Prdx in certain cells leads to higher basal amounts of ROS (Neumann C et al., 2003; Han YH et al., 2005; Egler RA et al., 2005). More importantly, the loss of $\operatorname{Prdx} 1$ or $\operatorname{Prdx} 2$ in erythrocytes leads to formation of Heinz bodies in the hemoglobin that leads to hemolytic anemia in those mice. In normal wild-type cells, there is a sequential peroxidase activity of catalase, GPXs and PRDXs to scavenge $\mathrm{H}_{2} \mathrm{O}_{2}$. Low amounts of $\mathrm{H}_{2} \mathrm{O}_{2}$ are scavenged by GPXs and PRDXs because they have a greater affinity for $\mathrm{H}_{2} \mathrm{O}_{2}$, while high amounts of $\mathrm{H}_{2} \mathrm{O}_{2}$ are primarily scavenged by catalase. Inactivation of the peroxidase activity by over-oxidation occurs with typical 2Cys PRDXs. For Prdx1, the redox active cysteine $\left(\mathrm{Cys}^{51}-\mathrm{SH}\right)$ is initially converted to sulfinic acid $\left(\mathrm{Cys}^{51}-\mathrm{SOH}\right)$; however, due to the slow kinetics of disulfide formation with the resolving cysteine $\left(\mathrm{Cys}^{172}-\mathrm{SH}\right)$; $\mathrm{Cys}^{51}-\mathrm{SOH}$ could be further oxidized to sulfonic acid $\left(\mathrm{Cys}^{51}-\mathrm{SO}_{2} \mathrm{H}\right)$. The sulfonic acid cysteine cannot form the disulfide bridge and thus unable to form the dimer required to decompose $\mathrm{H}_{2} \mathrm{O}_{2}$ (Cao J et al., 2009).

In addition to its role as an intracellular $\mathrm{H}_{2} \mathrm{O}_{2}$ scavenger, $\operatorname{Prdx} 1$ acts like a tumor suppressor gene (TSG) by protecting the lipid phosphatase activity of the well known TSG, phosphatase and tensin homolog 1 (Pten). The Prdx 1 protein binds to the Pten protein and minimizes its over-oxidation by $\mathrm{H}_{2} \mathrm{O}_{2}$, which reduces the extent of Akt hyperphosphorylation and Akt enzymatic activity (Cao J et al., 2009). Pten deficiency is a hallmark of many human tumors (Keniry and Parsons, 2008) and is accompanied by 
enhanced cell proliferation, decreased cell apoptosis and increased Akt activity (Stambolic et al, 1998). Additionally, the loss of Pten in mouse embryonic fibroblasts (MEFs) leads to elevated basal amounts of reactive oxygen species (ROS) as a result of decreased gene expression of Prdx1, Prdx2, Prdx5, Prdx6 and Sod1 (Huo YY et al., 2008).

The importance of Prdx 1 in the maintenance of homeostatic amounts of ROS has been observed in MEFs and erythrocytes but its importance in T cells and in ear fibroblasts is unknown. Therefore, in this study, the amounts of ROS were measured using a redox sensitive fluorescent probe in both cell types derived from young adult

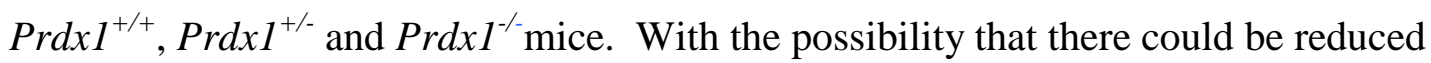
activity of Pten due to loss of Prdx1 in both cell types, I also measured gene expression of Pten regulated antioxidant genes along with other primary peroxidases, catalase and Gpx1. Furthermore, since amounts of ROS were higher in fibroblasts than in T cells across all Prdx 1 genotypes, peroxidase activity in the two cell types was measured by examining the extent of monomer, dimer and oligomer formation of the Prdx 1 protein in T cells and primary fibroblasts after treatment with increasing concentrations of $\mathrm{H}_{2} \mathrm{O}_{2}$. Finally, cultured fibroblasts from $\operatorname{PrdxI^{+/+}}$ and $\operatorname{Prdx1^{-/}}$ mice were treated with varying dosages of $\mathrm{H}_{2} \mathrm{O}_{2}$ in order to determine if there were differences in cell survival and whether that correlated with differences in the amounts of ROS. 


\subsection{Materials and Methods}

Mouse breeding

Mixed strain 129XC57 $\operatorname{Prdx} 1^{+/-}$and $\operatorname{Prdx} 1^{-/}$male mice were backcrossed to either 129 strain or C57 strain female wild-type (WT) mice for four generations. At each generation, microsatellite marker (MSM) analyses along chromosome 8 (D8Mit56, 271, 106, 125 and 155) was performed on male mice. The PCR recipe, the PCR conditions and the primer sequences for the MSMs utilizing tail DNA are listed in the tables below:

MSM genotyping recipe:

\begin{tabular}{|l|l|}
\hline & Volume \\
\hline REDExtract Reaction Mix & $10 \mu \mathrm{L}$ \\
\hline D8MIT-Forward $(10 \mu \mathrm{M})$ & $1 \mu \mathrm{L}$ \\
\hline D8MIT-Reverse $(10 \mu \mathrm{M})$ & $1 \mu \mathrm{L}$ \\
\hline DNA & $4 \mu \mathrm{L}$ \\
\hline $\mathrm{ddH}_{2} \mathrm{O}$ & $4 \mu \mathrm{L}$ \\
\hline
\end{tabular}

Microsatellite marker primer sequences:

\begin{tabular}{|r|l|l|l|}
\hline \multicolumn{1}{c|}{ M } & Marker & Forward Primer & Reverse Primer \\
\hline 76 & D8MIT56 & ACACTCAGAGACCATGAGTACACC & GAGTTCACTACCCACAAGTCTCC \\
\hline 61 & D8MIT271 & GGCAGAACCACAGGTTGATT & GGAATGAGGTTTGGGTCAAA \\
\hline 40 & D8MIT106 & TGTCACATACCCATGCGTG & AGCAAACGAGGGTGCAAG \\
\hline 21 & D8MIT125 & ATCGCTCTATCTACTCATCTATTCACA & GACCCTGACTCTTAATCCTAGTGC \\
\hline 2 & D8MIT155 & TTGGACAGGGAAAATCTGC & TGAGGACTTGCTTTAAGAGTACTCC \\
\hline
\end{tabular}


PCR conditions for MSM analyses:

\begin{tabular}{|l|l|l|l|l|}
\hline D8MIT56 & \multicolumn{3}{|c|}{30 cycles } & \\
\hline $94^{\circ} \mathrm{C}$ & $94^{\circ} \mathrm{C}$ & $56^{\circ} \mathrm{C}$ & $72^{\circ} \mathrm{C}$ & $72^{\circ} \mathrm{C}$ \\
\hline $3 \mathrm{~min}$ & $30 \mathrm{sec}$ & $30 \mathrm{sec}$ & $1 \mathrm{~min}$ & $7 \mathrm{~min}$ \\
\hline
\end{tabular}

\begin{tabular}{|l|l|l|l|l|}
\hline D8MIT155 & \multicolumn{3}{|c|}{30 cycles } & \\
\hline $94^{\circ} \mathrm{C}$ & $94^{\circ} \mathrm{C}$ & $56^{\circ} \mathrm{C}$ & $72^{\circ} \mathrm{C}$ & $72^{\circ} \mathrm{C}$ \\
\hline $3 \mathrm{~min}$ & $30 \mathrm{sec}$ & $30 \mathrm{sec}$ & $1 \mathrm{~min}$ & $7 \mathrm{~min}$ \\
\hline
\end{tabular}

\begin{tabular}{|l|l|l|l|l|}
\hline D8MIT125, 106 \& 271 & \multicolumn{3}{|c|}{30 cycles } & \\
\hline $94^{\circ} \mathrm{C}$ & $94^{\circ} \mathrm{C}$ & $56^{\circ} \mathrm{C}$ & $72^{\circ} \mathrm{C}$ & $72^{\circ} \mathrm{C}$ \\
\hline $3 \mathrm{~min}$ & $30 \mathrm{sec}$ & $30 \mathrm{sec}$ & $1 \mathrm{~min}$ & $7 \mathrm{~min}$ \\
\hline
\end{tabular}

The MSM analyses on chromosome 8 (location of Aprt) were done to determine the male mice that carried more of the strain specific markers, in order to determine the ideal mice to use for mating for the next generation. This is known as "speed congenics" and it was done to minimize the number of generations necessary to generate the pure 129 strain and the pure C57 strain mice for chromosome 8. The N4 $129 \operatorname{Prdx} 1^{+/-}$mice were then crossed with $129 \mathrm{Aprt}^{-/-}$mice to generate N5 $129 \mathrm{Prdxl}^{+/-} \mathrm{Aprt}^{+/-}$mice. These mice were then crossed with N4 C57 PrdxI ${ }^{+/}$mice to generate N5 129X N4 C57 hybrid Prdxl (+/+, +/- and -/-) Aprt $^{+/-}$mice.

Aprt and Prdx1 genotyping of Prdx1-Aprt mice

Mice were ear-tagged at approximately 4-6 weeks of age for proper mouse identification at a later time. DNA was extracted from the tail of the mouse using the REDExtract N-Amp Tissue PCR Kit (Sigma-Aldrich). A small piece of the tail was cut off and placed in 125 $\mu \mathrm{L}$ of a 4:1 mixture of Extraction Solution: Tissue Preparation Solution. The tail was vortexed rigorously and incubated at $55^{\circ} \mathrm{C}$ for 10 minutes, once 
again vortexed and incubated at $95^{\circ} \mathrm{C}$ for 3 minutes and again vortexed. Finally, $100 \mathrm{uL}$ of Neutralization Solution B was added to each tail with a final vortex. The tail DNA was then stored at $4^{\circ} \mathrm{C}$. PCR recipes for Aprt and Prdx 1 genotyping that includes the use of the REDExtract N-Amp PCR Master Mix (contains salts, buffer, dNTPs and Taq polymerase), primers and tail DNA:

\begin{tabular}{|l|l|}
\hline Aprt & Volume \\
\hline REDExtract PCR Mix & $10 \mu \mathrm{L}$ \\
\hline S2 $(100 \mathrm{ng} / \mathrm{uL})$ & $1 \mu \mathrm{L}$ \\
\hline MA009 $(100 \mathrm{ng} / \mathrm{uL})$ & $0.5 \mu \mathrm{L}$ \\
\hline Neo4 $(100 \mathrm{ng} / \mathrm{uL})$ & $1 \mu \mathrm{L}$ \\
\hline Tail DNA & $4 \mu \mathrm{L}$ \\
\hline dd $_{2} \mathrm{O}$ & $3.5 \mu \mathrm{L}$ \\
\hline Total & $20 \mu \mathrm{L}$ \\
\hline
\end{tabular}

\begin{tabular}{|l|l|}
\hline Prdx1 & Volume \\
\hline REDExtract PCR Mix & $10 \mu \mathrm{L}$ \\
\hline Int/2 $(5 \mu \mathrm{M})$ & $1 \mu \mathrm{L}$ \\
\hline $\mathrm{I} 3 / 3(5 \mathrm{uM})$ & $1 \mu \mathrm{L}$ \\
\hline Trn-Neo $(5 \mathrm{uM})$ & $1 \mu \mathrm{L}$ \\
\hline Tail DNA & $4 \mu \mathrm{L}$ \\
\hline ddH $_{2} \mathrm{O}$ & $3 \mu \mathrm{L}$ \\
\hline Total & $20 \mu \mathrm{L}$ \\
\hline
\end{tabular}

PCR conditions:

\begin{tabular}{|l|l|l|l|l|}
\hline Prdx1 & \multicolumn{3}{|c|}{35 cycles } & \\
\hline $95^{\circ} \mathrm{C}$ & $95^{\circ} \mathrm{C}$ & $60^{\circ} \mathrm{C}$ & $72^{\circ} \mathrm{C}$ & $72^{\circ} \mathrm{C}$ \\
\hline 3 min & $1 \mathrm{~min}$ & 1 min & 1 min & 5 min \\
\hline
\end{tabular}

\begin{tabular}{|l|l|l|l|l|}
\hline Aprt & \multicolumn{3}{|c|}{35 cycles } & \\
\hline $94^{\circ} \mathrm{C}$ & $94^{\circ} \mathrm{C}$ & $58^{\circ} \mathrm{C}$ & $72^{\circ} \mathrm{C}$ & $72^{\circ} \mathrm{C}$ \\
\hline $3 \mathrm{~min}$ & $30 \mathrm{sec}$ & $30 \mathrm{sec}$ & $55 \mathrm{sec}$ & $7 \mathrm{~min}$ \\
\hline
\end{tabular}

Primer Sequences:

\begin{tabular}{|l|l|}
\hline Prdx1 & Primer Sequence $\left(5^{\prime}-->3^{\prime}\right)$ \\
\hline Trn-Neo & CCTCCCCTACCCGGTAGAATTCGA \\
\hline I3/3 & CGTATAGCCCTGGCTGTCCTGGAT \\
\hline Int/2 & ACCTGAATTTGAGCCCCAGAAGACAAGT \\
\hline
\end{tabular}




\begin{tabular}{|l|l|}
\hline Aprt & Primer Sequence $\left(5^{\prime}-->3^{\prime}\right)$ \\
\hline S2 & ATAAGACCCTGCCCTTCCTCTACACA \\
\hline MA009 & ACAACCTTCCCTCCTGACCCTAACAG \\
\hline Neo4 & TGCCTGCTTGCCGAATATCATGGT \\
\hline
\end{tabular}

The expected allele sizes for Prdx1 were 630bp (WT) and 430bp (mutant). For Aprt, expected WT allele band size was 198bp and mutant allele band size was 398bp.

\section{$\underline{\text { Fibroblast cell culture }}$}

3-4 month old hybrid 129XC57 mice were killed by $\mathrm{CO}_{2}$ asphyxiation and each ear was collected in a well of a 12-well plate containing 3mL of 1X PBS (Mediatech, Inc.) with $100 \mu \mathrm{g} / \mathrm{mL}$ kanamycin (Sigma-Aldrich®). Each ear was washed with the PBSkanamycin mixture and transferred to a 24-well plate and minced in to small pieces. Approximately, $0.2 \mathrm{~mL}$ of $4 \mathrm{mg} / \mathrm{mL}$ Collagenase D (Roche Diagnostics) and Dispase II (natural protease grade II-Roche) mixture was added to each minced ear and allowed to incubate with the plate tilted in a $37^{\circ} \mathrm{C}-10 \% \mathrm{CO}_{2}-95 \%$ relative humidity $(\mathrm{RH})$ incubator for 45 minutes. After the 45 minute incubation, $1 \mathrm{~mL}$ of fibroblast medium (DMEMHigh Glucose w. 4mM L-Glutamine (Hyclone) medium supplemented with 10\% Fetal Bovine Serum (FBS) (Gibco), 1X MEM NEAA (Gibco), 1X Penicillin-Streptomycin (Pen-Strep) (Gibco) and 1X Fungizone-Amphotericin B (Gibco)) was added to each well and placed back in the incubator for overnight incubation. Following the overnight incubation, an additional $1 \mathrm{~mL}$ of fibroblast medium was added to each well along with $2 \mathrm{~mL}$ of fibroblast medium added to the surrounding empty wells. Each ear mixture was thoroughly mixed using a transfer pipette and added to a $50 \mathrm{~mL}$ tube fitted with a $70 \mu \mathrm{m}$ Nylon mesh cell strainer $\left(\mathrm{BD}\right.$ Falcon $\left.{ }^{\mathrm{TM}}\right)$. The cell strainer was washed with an additional $4 \mathrm{~mL}$ of fibroblast medium (from surrounding empty wells) and the collected cells were 
then centrifuged for 6 minutes at 1000 rpm using a Beckman Coulter Allegra 6 centrifuge. Supernatant was aspirated and $20.5 \mathrm{~mL}$ fibroblast medium was added to each $50 \mathrm{~mL}$ tube; $500 \mu \mathrm{L}$ was utilized for cell counting with the Beckman Coulter Vi-CELL® XR Cell Viability Analyzer with minimum and maximum cell diameter thresholds of $9 \mu \mathrm{m}$ and $17 \mu \mathrm{m}$, respectively. $1 \times 10^{5}$ cells were isolated in to a $1.5 \mathrm{~mL}$ micro-centrifuge tube for reactive oxygen species (ROS) measurements.

\section{$\underline{\text { Splenic T cells isolation and culture }}$}

Spleens were harvested from 3-4 month old 129XC57 hybrid mice and placed in a 12-well plate containing unsupplemented RPMI-1640 medium (Hyclone). The spleen was macerated with the plunger end of a $5 \mathrm{~mL}$ syringe and the cell suspension was taken up through a $5 \mathrm{~mL}$ syringe fitted with a sterile $5 / 8$ " 25 gauge needle. This cell suspension was added to a $15 \mathrm{~mL}$ centrifuge tube containing $3 \mathrm{~mL}$ of pre-warmed Lympholyte $\mathrm{M}$ (Cedar Lane) with an additional $3 \mathrm{~mL}$ of unsupplemented medium added to the $15 \mathrm{~mL}$ tube. The cell suspension was centrifuged at 2000rpm for 20 minutes using the Beckman Allegra 6 centrifuge. After the centrifugation, the middle layer of the cell suspension $(\sim 3 \mathrm{~mL})$ was added to a fresh $15 \mathrm{~mL}$ tube containing $5 \mathrm{~mL}$ of unsupplemented RPMI-1640 medium. This cell suspension was then centrifuged at $1600 \mathrm{rpm}$ for 8 minutes. The supernatant was discarded and 5mL of supplemented RPMI-1640 T cell medium (RPMI1640 medium with 10\% FBS, 2mM Glutamine (Gibco), 20mM HEPES (Sigma-Aldrich), 1mM Sodium Pyruvate (Gibco), 1X Pen-Strep (Gibco), 1X MEM NEAA (Gibco), 10,000 units of recombinant mouse IL-2 (Chemicon International) and 50 $\mu \mathrm{M}$ betamercaptoethanol ( $\beta$-ME) (Sigma-Aldrich $®$ ) was added to the $15 \mathrm{~mL}$ tube. In a $50 \mathrm{~mL}$ canted neck tissue culture flask (Beckton-Dickinson ${ }^{\mathrm{TM}}$ ), $15 \mathrm{~mL}$ of supplemented RPMI 
medium containing $4 \mu \mathrm{g} / \mathrm{mL}$ jack bean derived concanavalin A (ConA) (Sigma-Aldrich $®)$ was added along with the $5 \mathrm{~mL}$ cell suspension from the $15 \mathrm{~mL}$ tubes. The cap of the flask was loosened to allow for proper $\mathrm{CO}_{2}$ exchange and placed at an angle $\left(\sim 45^{\circ}\right)$ in a $37^{\circ} \mathrm{C}-7 \% \mathrm{CO}_{2}-95 \% \mathrm{RH}$ incubator and allowed to incubate overnight. After the overnight incubation, $250 \mu \mathrm{L}$ of the cell suspension was added to a cuvette containing $250 \mu \mathrm{L}$ of $1 \mathrm{X}$ PBS to be used for counting by the Vi-CELL Cell Viability Analyzer. Minimum and maximum thresholds for T cells were $8.3 \mu \mathrm{m}$ and $17 \mu \mathrm{m}$, respectively. Like the fibroblasts, $1 \mathrm{X} 10^{5}$ cells were separated in to a $1.5 \mathrm{~mL}$ microcentrifuge tube for ROS measurements.

\section{$\underline{\text { ROS measurements in ear fibroblasts and T cells }}$}

$1 \times 10^{5} \mathrm{~T}$-cells and fibroblasts in $1 \mathrm{~mL}$ of the respective supplemented medium were incubated with $5 \mu \mathrm{M}$ of 5-(and-6)-chloromethyl-2',7'-dichlorodihydrofluorescein diacetate (DCF) (Invitrogen ${ }^{\mathrm{TM}}$ ) for 22 minutes in the dark at $37^{\circ} \mathrm{C}$. Background controls included each supplemented medium with cells but without DCF. The cells were spun down at $1600 \mathrm{rpm}$ for 5 minutes, the medium aspirated and resuspended in $500 \mu \mathrm{L}$ of $1 \mathrm{X}$ PBS for flow cytometry analysis. The analysis was done using the Beckman Coulter FC500 Analyzer with 10,000 cells gated for each cell type and fluorescence measured using the FL1 channel. Student t-test using Microsoft Excel was used to calculate significance between $\operatorname{Prdx} 1$ genotypes in each respective cell type with $\mathrm{p}<0.05$ considered significant.

$\underline{\text { RNA extraction from primary fibroblasts and T-cells }}$

RNA extraction was done using the RNeasy Mini Kit (Qiagen). The ears and spleens from 3-4 month old $\operatorname{Prdx} 1^{+/+}$and $\operatorname{Prd} x 1^{-/-} 129 \mathrm{XC} 57$ mice (n=3 each) were gathered as previously described. Each ear was plated on to two-100mm plates and 
grown to $60-70 \%$ confluency with a change of medium around 3 days after the initial plating. Fibroblasts were collected via trypsinization, counted using the Vi-CELL® XR Cell Viability Analyzer. Approximately $1 \times 10^{6}$ primary fibroblasts were spun down at $1000 \mathrm{rpm}$ for 5 minutes, medium was aspirated and the cell pellet resuspended in $600 \mu \mathrm{L}$ of RLT buffer (Qiagen) supplemented with $6 \mu \mathrm{L}$ of beta-mercaptoethanol ( $\beta-\mathrm{ME}) .1 \times 10^{6}$ concanavalin (ConA) stimulated T cells were also collected, they were spun down at $1600 \mathrm{rpm}$ for 5 minutes and the cell pellet re-suspended in $600 \mu \mathrm{L}$ of RLT buffer supplemented with $\beta$-ME. Afterwards, $600 \mu \mathrm{L}$ of $70 \%$ ethanol (EtOH) was added to the $\beta$-ME-RLT cell (fibroblasts and T cells) suspension and mixed thoroughly and then transferred to RNeasy spin column in $700 \mu \mathrm{L}$ volume increments. Each subsequent spin down except for the final elution step was done at 10,000 rpm with the flow-through solution discarded. The 70\% EtOH- $\beta$-ME-RLT cell suspension was spun down each time for 15 seconds (sec) and followed by the addition of $350 \mu \mathrm{L}$ of RW1 buffer to the spin column with a centrifugation for $15 \mathrm{sec}$. Then, $80 \mu \mathrm{L}$ of DNase I (10uL DNase I (Qiagen) and 70 $\mu$ L RDD buffer (Qiagen)) was added to the middle of the spin column and allowed to incubate for 15 minutes at room temperature, prior to centrifugation for 15 sec. Once again, $350 \mu \mathrm{L}$ of RW1 buffer was added to the spin column and centrifuged for $15 \mathrm{sec}$. It was followed up by two washes with RPE buffer with the first centrifugation for $15 \mathrm{sec}$ and the second centrifugation for 2 minutes. The tubes were then centrifuged for 1 minute to remove any residual wash buffer. The spin column was placed in to a $1.5 \mathrm{~mL}$ RNase free microcentrifuge tube and $30 \mu \mathrm{L}$ of RNase free water was added to the column and allowed to sit for 1-2 minutes before it was centrifuged at 13,200rpm for 1 minute. Concentrations, 260/230 and 260/280 values (measurement of possible 
contaminants in RNA solution) of all RNA samples were determined using the ND-1000

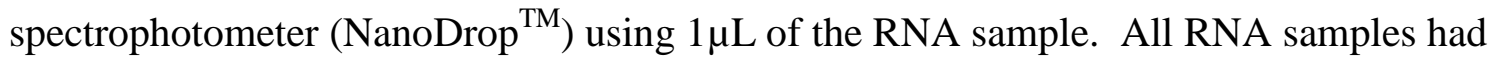
$260 / 230$ and $260 / 280$ values greater than 1.7 , which ensures minimum contamination of protein and salts. The integrity of the RNA based on 18s and 28s bands (two clear distinct bands) was determined by loading $1 \mu \mathrm{L}$ of the RNA solution with $1 \mu \mathrm{L}$ of $5 \mathrm{X}$ Green GoTaq ${ }^{\mathrm{TM}}$ reaction buffer and $3 \mu \mathrm{L}$ of RNase free water into each well of a $1 \%$ ethidium bromide agarose gel and run at 90 volts for 20 minutes.

\section{$\underline{\text { Tissue extraction }}$}

6 month old $\operatorname{Prdx} 1^{+/+}$and $\operatorname{Prdx} 1^{-/-} 129 \mathrm{XC57}$ strain mice were sacrificed by cervical dislocation. Spleen, kidney and lung tissue were immediately removed and cut into half in preparation for subsequent protein and RNA isolations. The tissues were then placed into $1.5 \mathrm{ml}$ centrifuge tubes containing $350 \mu \mathrm{l}$ of BME-RLT buffer, a mixture of buffer RLT (Qiagen) supplemented with 1:100 volume of beta-mercaptoethanol ( $\beta$-ME). Spleen samples were homogenized using a Polytron PT 2100 (Kinematica) homogenizer, while lung and kidney samples were ground up using a motorized mortar and pestle, with the lysate homogenized using a QIAshredder (Qiagen) spin-column and centrifuged at $13,200 \mathrm{rpm}$ for 2 minutes. The homogenized lysates were stored at $-80^{\circ} \mathrm{C}$ for later use. RNA extraction from the whole spleen lysates was done as previously described for the fibroblast and T cell lysates.

\section{Quantitative real-time PCR (qRT-PCR) experiments}

Expression of the following genes was measured in $\operatorname{Pr} d x 1^{+/+}$and $\operatorname{Pr} d x 1^{-/}$T-cells, primary fibroblasts and whole spleen tissue: Catalase, glutathione peroxidase 1 (Gpx1), peroxiredoxin $1(\operatorname{Prdx} 1), \operatorname{Prdx} 2, \operatorname{Prdx} 5$, Prdx6, and copper-zinc superoxide dismutase 
(Sod1). Beta-actin ( $\beta$-actin) was used as the loading control for the fibroblast and $\mathrm{T}$ cell analyses while glyceraldehyde-3-phosphate dehydrogenase (GAPDH) was used for the whole spleen tissue analyses. Reverse transcription PCR recipe using the TaqMan® Reverse Transcription Reagents (Applied Biosystems ${ }^{\mathrm{TM}}$ ) was as follows:

\begin{tabular}{|l|c|}
\hline Reagent & uL per sample \\
\hline Taq RT Buffer & 1 \\
\hline MgCl & 2.2 \\
\hline dNTP & 2 \\
\hline Random Hexamers & 0.25 \\
\hline Oligo(dt) & 0.25 \\
\hline RNAse Inhibitor & 0.2 \\
\hline Multiscribe & 0.25 \\
\hline RNA+water & 3.85 \\
\hline Total & 10 \\
\hline
\end{tabular}

The cDNA samples were run after they were diluted 1:8 in RNase-free water while the standards were diluted 1:4, 1:16 and 1:64. $\operatorname{Prd} x 1^{+/+}$T cell, $\operatorname{Prd} d x 1^{+/+}$fibroblast and

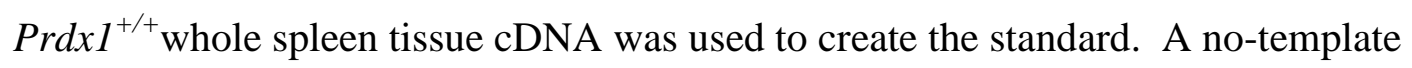
control (NTC) was included in all runs as a negative control. For each sample, the following SYBR Green master mix was made: $0.4 \mu \mathrm{L}$ of forward primer $(5 \mu \mathrm{M}), 0.4 \mu \mathrm{L}$ of reverse primer $(5 \mu \mathrm{M}), 11.2 \mu \mathrm{L}$ of $\mathrm{ddH}_{2} \mathrm{O}$ and $15 \mu \mathrm{L}$ of SYBR Green for a total of $27 \mu \mathrm{L}$. This master mix was multiplied by (\# of samples + 1) to make a master mix for each primer pair (reverse and forward). SYBR Green was added last and mixed at least 25 times with a micropipette. The $27 \mu \mathrm{L}$ mixture was then added to each well of a conical 96-well PCR plate. Then $3 \mu \mathrm{L}$ of the diluted cDNA samples and the different standards were added with a multi-channel pipette to the 96-well conical plate and mixed $\sim 30 \mathrm{X}$. The plate was sealed and spun down at $2000 \mathrm{rpm}$ for 5 minutes. Then with the aid of a 
multi-channel pipette, the $30 \mu \mathrm{L}$ mixture was mixed again $30 \mathrm{X}$ with $9.0 \mu \mathrm{L}$ then transferred to the respective wells of a 384-well plate. The plate was sealed and spun down again at $2000 \mathrm{rpm}$ for 5 minutes. The template of the 384 -well to illustrate the locations of unknowns and standards for each primer pair was created using the SDS software that controls the Applied Biosystems 7900HT Sequence Detection System. The qRT-PCR program was as follows: $50^{\circ} \mathrm{C}$ for $2 \mathrm{~min}, 95^{\circ} \mathrm{C}$ for $10 \mathrm{~min}$ followed by 40 cycles of $\left(95^{\circ} \mathrm{C}\right.$ for $15 \mathrm{~s}$ and $60^{\circ} \mathrm{C}$ for $\left.1 \mathrm{~min}\right)$. The primer sequences are listed in Table 1 and were designed using the Primer Express v2.0 software.

Table 1. Sequence of RT primers of antioxidant genes used in qRT-PCR experiments.

\begin{tabular}{lll}
\hline Gene & Forward Primer & Reverse Primer \\
\hline & & \\
B-actin & GACGGCCAGGTCATCACTATTG & AGTTTCATGGATGCCACAGGAT \\
Catalase & CCATCGCCAATGGCAATTAC & AGGCCAAACCTTGGTCAGATC \\
Gpx1 & CCGCTTCGTACCATCGACAT & CCAGTAATCACCAAGCCAATGC \\
Prdx1 & AGTCCAGGCCTTCCAGTTCACT & GGCTTGATGGTATCACTGCCAG \\
Prdx2 & AAGGACACCACTGGCATCGAT & CACACAATTACGGCGTGTTGAA \\
Prdx5 & GTGTTTGTTGGAGTCCCTGG & AATAACGCTCAGACAGGCCAC \\
Prdx6 & TTTGAGGCCAATACCACCATC & TGCCAAGTTCTGTGGTGCA \\
Sod1 & AAGCATGGCGATGAAAGCG & ACAACACAACTGGTTCACCGC \\
& & \\
\hline
\end{tabular}

The ideal primers were chosen based on the following criteria: low penalty scores, forward and reverse primer pair located in separate exons and only specific for the gene of interest. The specificity was determined by performing a query of each primer using the Nucleotide BLAST ${ }^{\mathrm{TM}}$ online software (NCBI) against the Mus Musculus nucleotide collection database. Each sample-primer pair was run in triplicate and a total of 3 mice of each genotype were used.

Prdx 1 protein expression in $\mathrm{H}_{2} \underline{\mathrm{O}}_{2}$ treated primary fibroblasts and T-cells

Primary ear fibroblasts and ConA stimulated T-cells from 3-4 month old wildtype mice were isolated and cultured as described in the RNA expression studies. For 
this study, $1 \times 10^{6} \mathrm{~T}$-cells and $1 \times 10^{6}$ ear fibroblasts suspended in $1 \mathrm{~mL}$ of their respective medium were used for each treatment group. Different concentrations of $\mathrm{H}_{2} \mathrm{O}_{2}(0,20 \mu \mathrm{M}$, $50 \mu \mathrm{M}$ and $250 \mu \mathrm{M}$ ) were added directly to each cell suspension and incubated for 15 minutes in a $37^{\circ} \mathrm{C}, 95 \% \mathrm{RH}$ and $10 \% \mathrm{CO}_{2}$ incubator. The suspension was then centrifuged, the pellet was washed with PBS, centrifuged with supernatant removed and the pellet resuspended in $150 \mu \mathrm{L}$ of protein extraction buffer $(20 \mathrm{~mm}$ (hydroxyethyl piperazineethanesulfonic acid (HEPES) and 0.1\% Triton X-100, pH 7.4) with 1:100 dilution of protease inhibitor cocktail (104mM of 4-(2-Aminoethyl) benzenesulfonyl fluoride hydrochloride (AEBSF), 80 $\mathrm{M}$ Aprotinin, 4mM Bestatin, 1.4mM E-64, 2mM Leupeptin and 1.5mM Pepstatin A (Sigma)). The pellet was then centrifuged at 4000xg with the supernatant collected and aliquoted in to separate microcentrifuge tubes. Protein concentration was determined by the bicinchoninic acid (BCA) assay in a 96-well microplate using bovine serum albumin (BSA) to create the protein standards. Each well of a microplate contained $2 \mu \mathrm{L}$ of the protein sample or the appropriate amount of standard $(0,1,2,5,10,20$ and $40 \mu \mathrm{g}$ of BSA) diluted in water to a total volume of $20 \mu \mathrm{L}$.

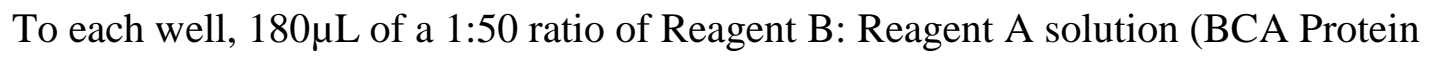
Assay Kit (Pierce)) was added to each well. The plate was then mixed by shaking it in the Molecular Devices SpectraMax M2 plate reader for 5 seconds and then incubated at $37^{\circ} \mathrm{C}$ for 30 minutes. The plate was allowed to cooled down to room temperature before the absorbance was measured at 562nm using the Molecular Devices SpectraMax M2 plate reader. With the SoftMax Pro 4.7.1 software that is used with the plate reader, a standard curve was created by inputting the locations of the BSA standard $(0,1,2,5,10$, 20 and $40 \mu \mathrm{g}$ ) in to the appropriate well of the 96-well plate template. The locations of 
the unknown protein samples were also inputted. The protein amounts of the unknown samples were determined from the standard curve with the concentration $(\mu \mathrm{g} / \mu \mathrm{L})$ calculated by dividing the amount value by 2 (volume $(\mu \mathrm{L})$ of unknown sample in each well). $30 \mu \mathrm{g}$ of protein was analyzed for $\operatorname{Prdx} 1$ and $\operatorname{Prdx} 1 \mathrm{C} 53 \mathrm{SO}_{3}$ protein expression under non-reducing and reducing (beta-mercaptoethanol added to extraction buffer) conditions. Beta-actin was used as a loading control. All antibodies were from Abcam. Measurement of ROS amounts in cultured fibroblasts

ROS amounts were measured in fibroblasts derived from 4 month old $\operatorname{Prdx} \mathrm{I}^{+/+}$ and $\operatorname{Prd} x 1^{-/-} 129 \mathrm{XC} 57$ strain mice. $5 \times 10^{4}$ cells were plated in each well of a 12-well plate and allowed to grow for 2 days prior to hydrogen peroxide $\left(\mathrm{H}_{2} \mathrm{O}_{2}\right)$ treatment. $10.23 \mathrm{M}$ $\mathrm{H}_{2} \mathrm{O}_{2}$ (Sigma-Aldrich) solution was serially diluted autoclaved $\mathrm{ddH}_{2} \mathrm{O}$ to an $80 \mathrm{mM}$ solution immediately before addition to the cells. The final dilution was made in serumfree fibroblast medium in a $15 \mathrm{~mL}$ centrifuge tube and then added directly to the cells (with the old fibroblast medium removed). For the untreated sample set, cells were incubated with just serum-free fibroblast medium. Incubation of all the samples was for 1 hour $(\mathrm{Hr})$ in a $37^{\circ} \mathrm{C}, 95 \% \mathrm{RH}$ and $10 \% \mathrm{CO}_{2}$ incubator. After the $1 \mathrm{Hr}$ treatment, the medium was removed, the cells washed with 1X PBS and allowed to recover in fibroblast medium with $10 \%$ FBS for 24 hours. After the 24 hours, the medium in each well was replaced with $1 \mathrm{~mL}$ of phenol-red free DMEM (Gibco) medium and $1 \mu \mathrm{L}$ of $5 \mathrm{mM} 5$-(and6)-chloromethyl-2',7'-dichlorodihydrofluorescein diacetate (DCF) (diluted in DMSO) was added to each well except for the wells designated as background controls. The cells were incubated for 30 minutes in the dark prior to fluorescence detection using the Molecular Devices SpectraMax M2 plate reader. Excitation and emission wavelengths of 
488nm and 525nm were used, respectively. Data was collected using the SoftMax Pro 4.7.1 and subsequent data analysis was done using Microsoft Excel. Each sample was run in triplicate for each experimental set and the data presented is an average of three independent experimental runs.

$\underline{\text { Cell survival analyses in cultured fibroblasts }}$

Approximately 10,000 fibroblasts (passage 2-4) in 100 $\mathrm{L}$ of medium were plated in each well of a 96-well flat bottom cell culture plate and allowed to grow for 2 days prior to $\mathrm{H}_{2} \mathrm{O}_{2}$ treatment. $\mathrm{H}_{2} \mathrm{O}_{2}$ treatment and subsequent recovery was done in the same manner as it was done for the ROS measurements. The CellTiter 96® AQueous NonRadioactive Cell Proliferation Assay, which is comprised of two reagents, a tetrazolium compound (MTS) and an electron coupling agent, PMS was used to measure cell survival. These two reagents were mixed together prior to addition to the cells. For each well, $20 \mu \mathrm{L}$ of MTS-PMS solution was added to $100 \mu \mathrm{L}$ of phenol red free DMEM medium. The plates were incubated at $37^{\circ} \mathrm{C}$ for at least 1 hour prior to absorbance measurements taken with the Molecular Devices SpectraMax M2 plate reader. The principle underlying the assay is that the MTS-PMS solution is bioreduced by living cells to a formazan by-product that can be measured by absorbance at 490nm. Therefore, the amount of absorbance at 490nm is directly proportional to the number of surviving cells. For each experiment, each sample set was run in quintuplicate and the data presented is the average of three independent experimental runs. Data analysis was done using Microsoft Excel.

$\underline{\text { RNA expression analyses of } \mathrm{H}_{2}} \underline{\mathrm{O}}_{2} \underline{\text { treated cultured ear fibroblasts }}$

For RNA extraction, approximately $6 \times 10^{5}$ cultured ear fibroblasts were plated on to $100-\mathrm{mm}$ cell culture dishes. They were allowed to grow for 2 days prior to $\mathrm{H}_{2} \mathrm{O}_{2}$ 
treatment in the same manner as it was done for the ROS and cell survival measurements. All the cells were collected for RNA extraction. RNA extraction, measurement of RNA concentration, 260/280 and 260/230 values and integrity of RNA gel analyses was done as previously described for the $\mathrm{T}$ cells and primary fibroblasts. The cDNA was also created in the same manner as described for the $\mathrm{T}$ cells and primary fibroblasts. The untreated $\operatorname{Prdx1^{+/+}}$ sample was used to create the standard; the setup for qRT-PCR and the subsequent analyses was the same as it was for the $\mathrm{T}$ cells and the ear fibroblasts. Beta-actin was used as the loading control.

\section{$\underline{\text { Statistical Analyses }}$}

Student t-test analysis was utilized to determine significance for DCF fluorescence measurements, with $\mathrm{p}<0.05$ considered significant. For the gene expression analyses, a significant change was considered to be $\geq 2$-fold difference with $\mathrm{p}<0.05$ as determined by the student t-test. 


\subsection{Results}

Increased ROS amounts in ear fibroblasts and T cells of $\operatorname{Prd} x 1^{-/-}$mice

Previous studies have shown that the loss of Prdx1 in MEFs and erythrocytes led to significant elevation in the intracellular amounts of ROS (Neumann C et al., 2003; Egler RA et al., 2005); therefore, I wanted to determine if it had a similar effect in T cells and in ear fibroblasts. ROS amounts were quantified by measuring the fluorescence of intracellular 5-(and-6)-chloromethyl-2',7'-dichlorodihydrofluorescein diacetate (DCF) that is cleaved by intracellular esterases and made fluorescent under oxidizing conditions (Yuan et al., 1993). Indeed, significantly higher amounts of ROS were observed with the complete loss of Prdx1 in both T cells and fibroblasts; ROS amounts were unchanged in

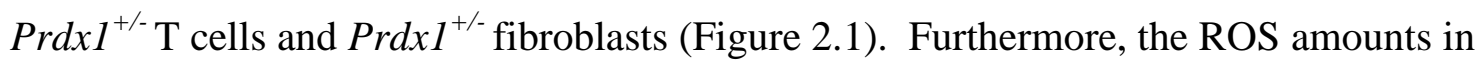
fibroblasts were higher than in T cells. In order to determine if this was due to differences in Prdx 1 peroxidase activity between cell types, we examined monomer, dimer and oligomer formation of the Prdx1 protein in $\operatorname{Prdx} 1^{+/+} \mathrm{T}$ cells and primary fibroblasts after treatment with increasing concentrations of $\mathrm{H}_{2} \mathrm{O}_{2}$. The reduction of $\mathrm{H}_{2} \mathrm{O}_{2}$ to $\mathrm{H}_{2} \mathrm{O}$ and $\mathrm{O}_{2}$ by $\operatorname{Prdx} 1$ requires the formation of a disulfide bridge between the two monomers resulting in a dimer. In fibroblasts, with increasing dosages of $\mathrm{H}_{2} \mathrm{O}_{2}$, we found a gradual decrease in dimer formation with a corresponding increase in monomer formation (Figure 2.2-top panel). This concurrent change was not observed in T cells except at the highest $\mathrm{H}_{2} \mathrm{O}_{2}$ treatment $(250 \mu \mathrm{M})$ (Figure 2.2-top panel). 


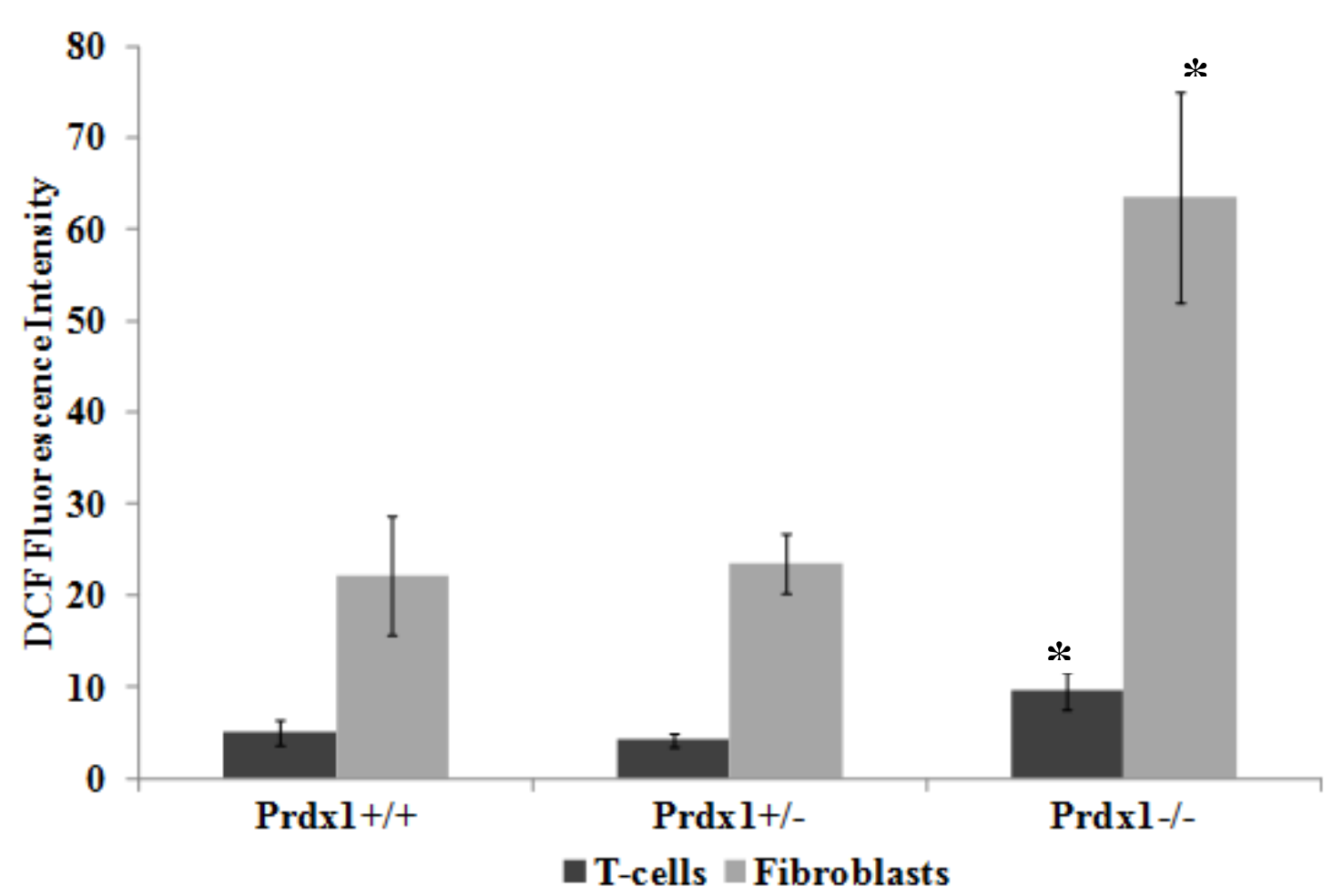

Figure 2.1. DCF fluorescence intensity measured by flow cytometry in T cells and fibroblasts isolated from $\operatorname{Prdx} 1^{+/+}, \operatorname{Prdx1^{+/}}$ and $\operatorname{Prdx} 1^{-/-}$mice. $* \mathrm{p}<0.05$ compared to

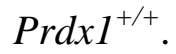

Moreover, we observed only in the fibroblasts reducible Prdx1 oligomers, which decreased after $\mathrm{H}_{2} \mathrm{O}_{2}$ treatment, suggesting higher $\mathrm{H}_{2} \mathrm{O}_{2}$-induced over-oxidation of Prdx1 in fibroblasts compared to T cells. Along those lines, an antibody specifically detecting Prdx 1 over-oxidized at the catalytic cysteine revealed a higher amount of over-oxidized Prdx1 in fibroblasts compared to T cells (Figure 2.2-bottom panels). 


\section{Fibroblasts}

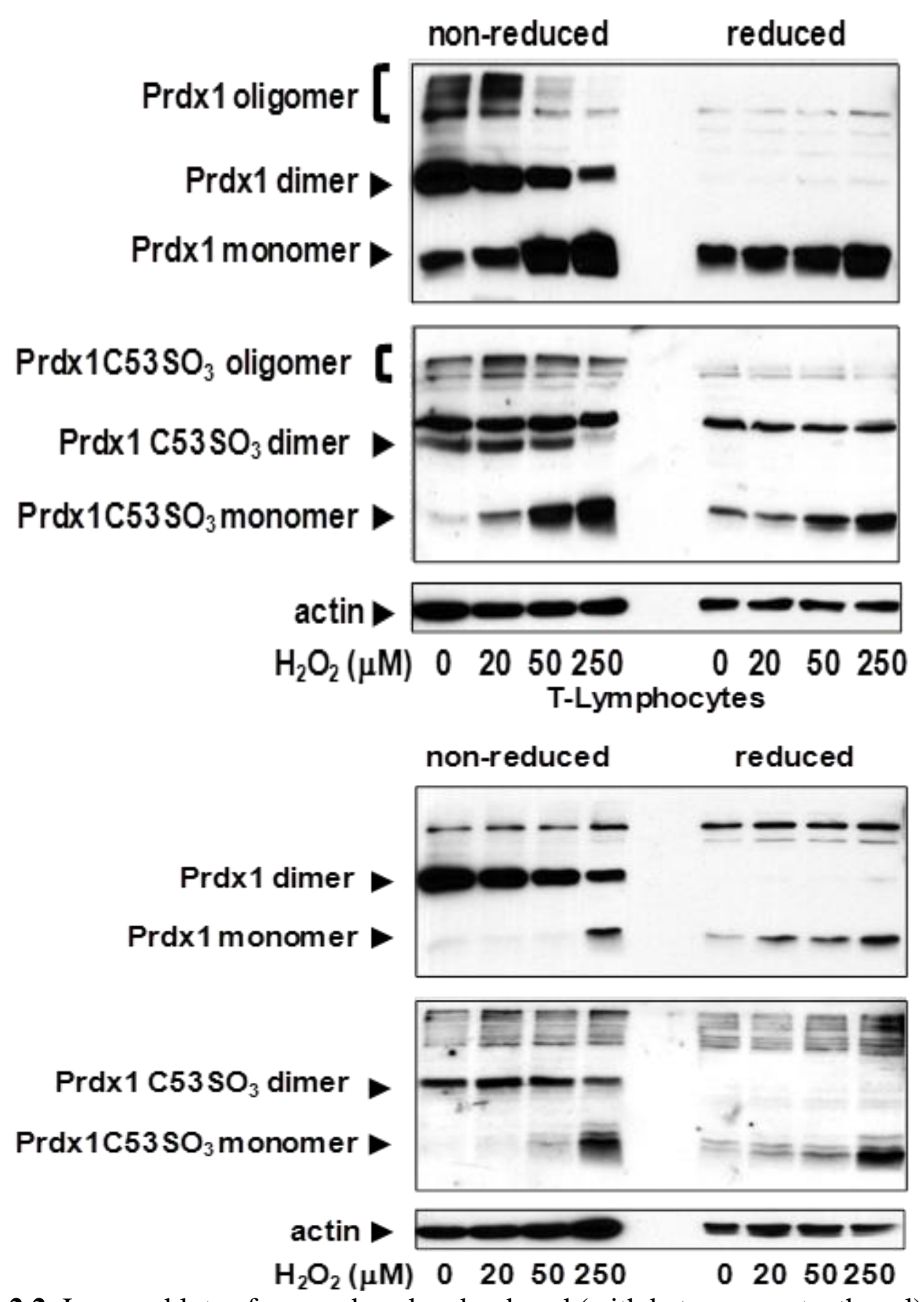

Figure 2.2. Immunoblots of non-reduced and reduced (with beta-mercaptoethanol) protein lysates measuring expression of normal Prdx1 (top panel) and oxidized (Prdx1C53SO 3 -bottom panel) protein in $\mathrm{H}_{2} \mathrm{O}_{2}$ treated samples. A) Primary fibroblasts and $\mathbf{B})$ Splenic T cells. $30 \mu \mathrm{g}$ of protein was loaded per lane. 
$\underline{\text { Transcriptional expression of antioxidant genes unaffected in } \operatorname{Prdx} 1^{-/-} \text {cells }}$

The Prdx 1 protein binds to and protects the phosphatase and tensin homolog 1 (Pten) protein from oxidation-induced inactivation, thus acting as a safeguard of Pten (Cao et al., 2009). I hypothesized that the loss of Prdx 1 could lead to greater Pten inactivation in $\operatorname{Prdx} 1^{-/}$T cells and $\operatorname{Prdx} 1^{-/}$primary fibroblasts as Pten is known to positively regulate expression of). Therefore, the possible inactivation of Pten could result in transcriptional down-regulation of genes that encode antioxidant proteins (Huo et al., 2008) that can contribute to the elevated ROS amounts observed in $\operatorname{Prdx} 1^{-/-} \mathrm{T}$ cells and $\operatorname{Prdx} 1^{-/}$primary fibroblasts (Figure 2.1). In addition to the genes that are Pten regulated, I also examined the transcriptional expression of other important $\mathrm{H}_{2} \mathrm{O}_{2}$ scavengers, catalase and glutathione peroxidase 1 (Gpx1). In both cell types, the loss of Prdx 1 did not lead to differences in transcription $(<2$-fold) of any of the measured antioxidant genes (Figure 2.3). Therefore, the increased ROS amounts observed in $\operatorname{Prd} x 1^{-/-}$splenic T-cells and $\operatorname{Prd} x 1^{-/}$ear fibroblasts seem to be due to loss of Prdx 1 functionality and independent of changes in the activity of Pten. 

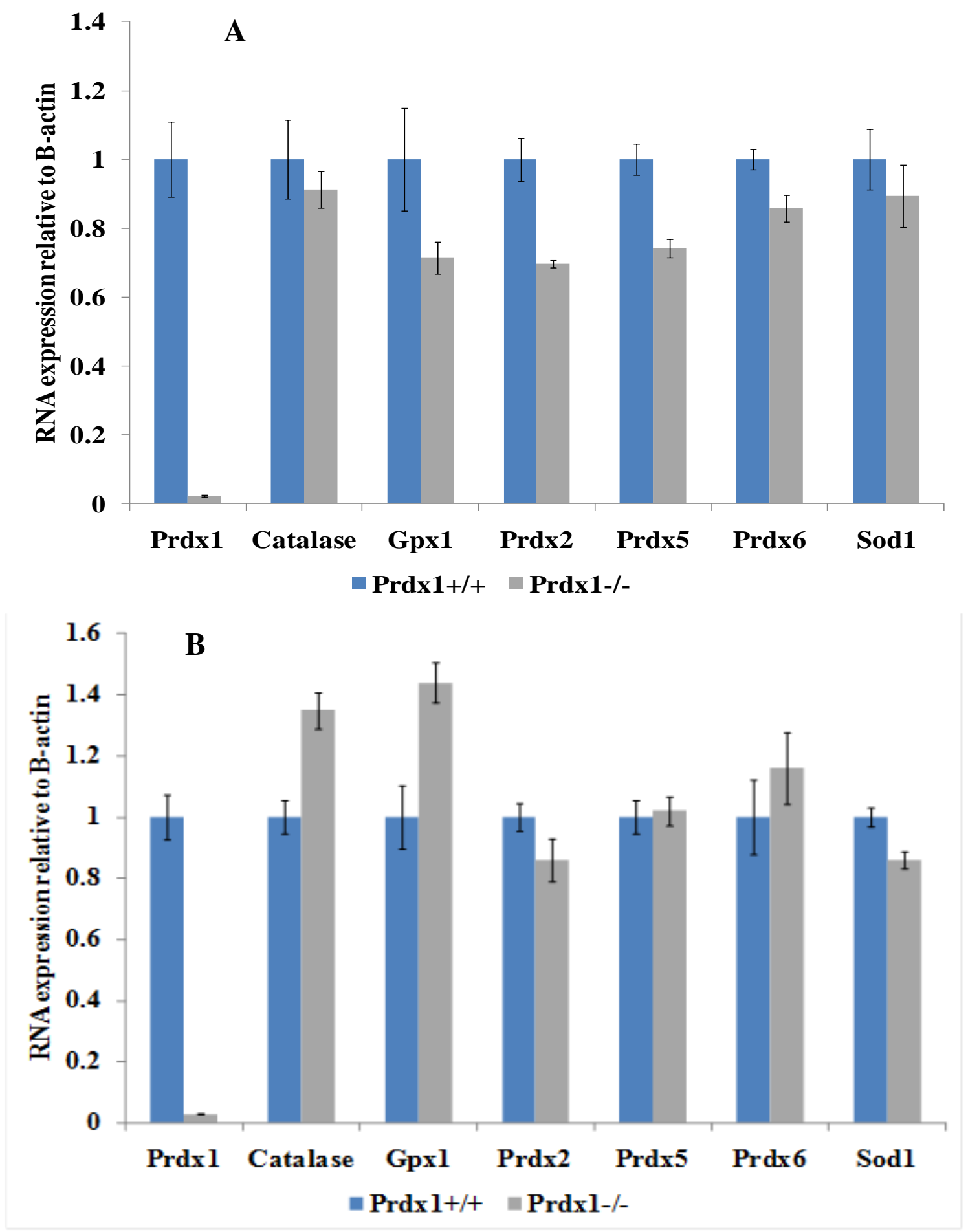

Figure 2.3. Relative mRNA expression of various antioxidant genes in $P r d x 1^{+/+}$and $\operatorname{Prdx} 1^{-/-}$A) T cells and B) primary fibroblasts. All $\operatorname{Prdx1^{++}}$ values were normalized to 1 . 
$\underline{\text { Induction in expression of } \mathrm{H}_{2} \underline{\mathrm{O}}_{2}} \underline{\text { scavenger genes in } \operatorname{Prdx} 1^{-/-} \text {whole spleen tissue }}$

To understand if the findings in splenic $\mathrm{T}$ cells represented the tissue from which they were derived, I measured RNA expression of the same antioxidant genes in the whole spleen tissue. In direct contrast to the findings in $\operatorname{Prdx} 1^{-/-}$T-cells, RNA expression analyses of $\operatorname{Prdx} 1^{-/}$whole spleen tissue revealed significant induction (> 2-fold) over $\operatorname{Prdx} 1^{+/+}$in the expression of catalase, Gpx1, Prdx2 and Prdx6 (Figure 2.4).

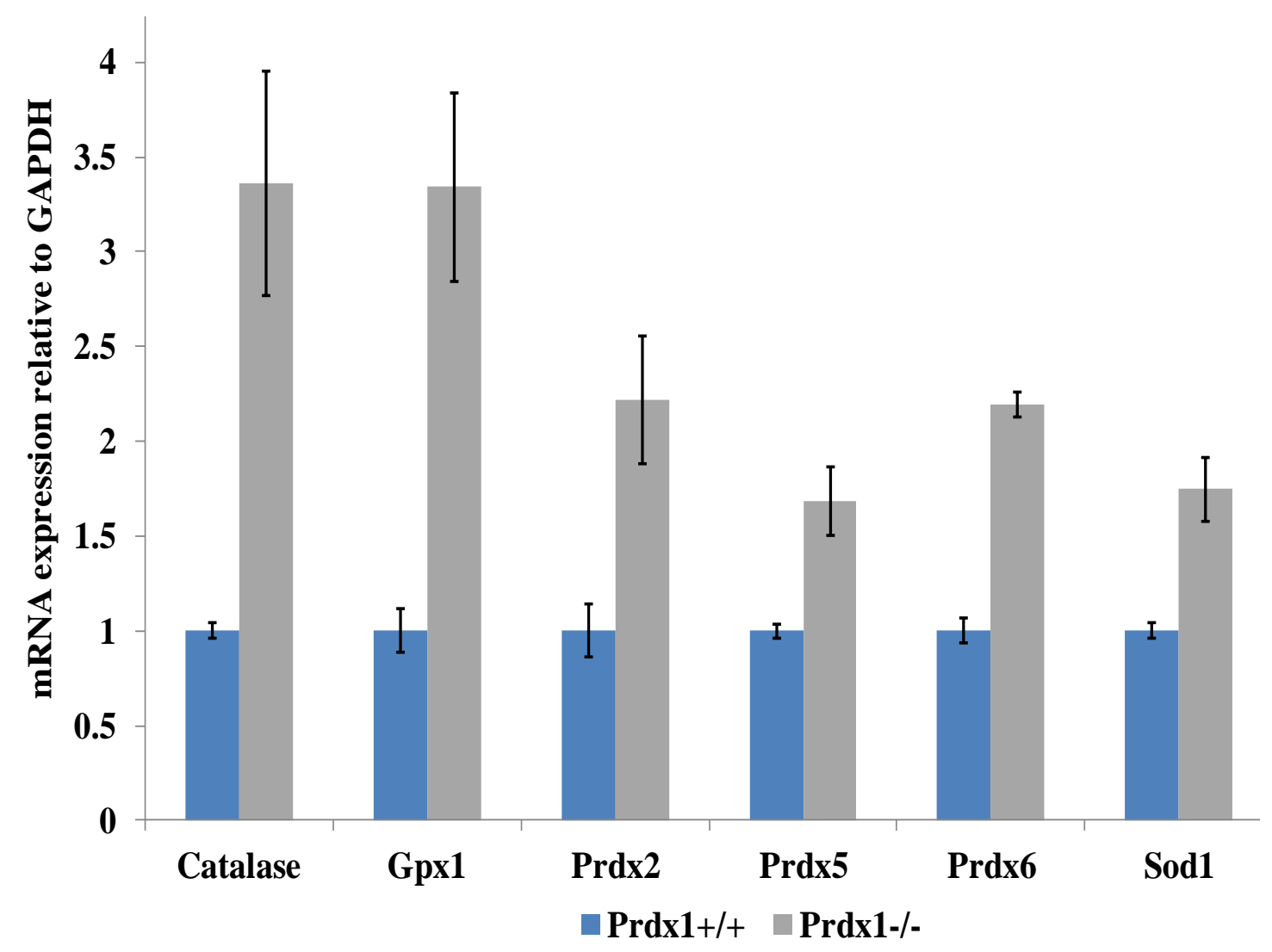

Figure 2.4. RNA expression analyses of various genes that encode antioxidant proteins in the whole spleen tissue derived from 6 month old $\operatorname{Prdx1^{+/+}}(\mathrm{n}=4)$ and $\operatorname{Prdx} 1^{-/}(\mathrm{n}=3)$ mice. All $\operatorname{Prdxl^{+/+}}$ values were normalized to 1 .

$\underline{\text { ROS amounts unaffected with Prdx } 1 \text { loss after } \mathrm{H}_{2} \underline{\mathrm{O}}_{2} \text { treatment of cultured fibroblasts }}$

To further elucidate the importance of Prdx1 in the maintenance of homeostatic amounts of ROS, I treated cultured ear fibroblasts derived from 4 month $\operatorname{PrdxI^{+/+}}$ and $\operatorname{Prdx} 1^{-/}$mice with different dosages of $\mathrm{H}_{2} \mathrm{O}_{2}$ ( 1 hour treatment with 24 hour recovery). 
At the lowest dosage $(50 \mu \mathrm{M})$ of $\mathrm{H}_{2} \mathrm{O}_{2}$, there was a decrease in the amounts of ROS in $\operatorname{PrdxI}^{+/+}$and $\operatorname{PrdxI^{-/}}$ cells (Figure 2.5) with no significant difference between them. The amounts of ROS increased slightly at the $800 \mu \mathrm{M}$ dosage but were still significantly lower than the basal amounts of each respective sample and once again with no significant difference between $\operatorname{PrdxI^{+/+}}$ and $\operatorname{Prdx1^{-/}}$ cells.

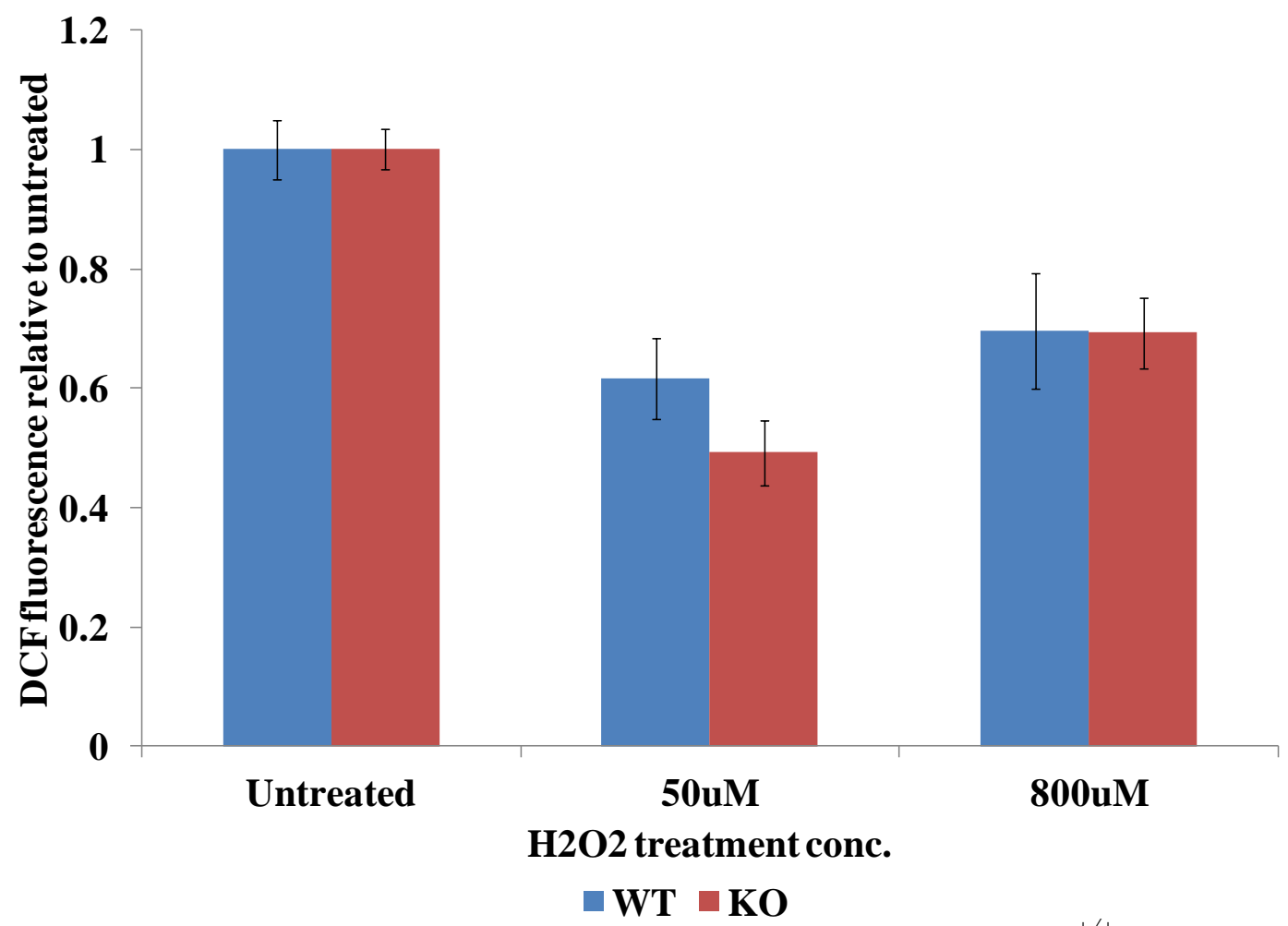

Figure 2.5. DCF fluorescence in cultured fibroblasts derived from $\operatorname{Prdx} \mathrm{I}^{+/+}$and $\operatorname{Prd} d x \mathrm{I}^{-/-}$ mice after treatment with $\mathrm{H}_{2} \mathrm{O}_{2}$. Untreated samples were normalized to 1 .

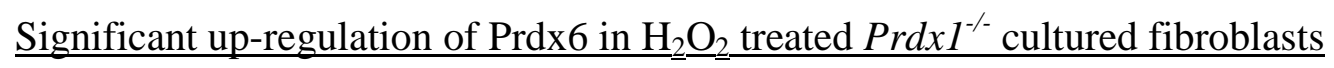

In order to elucidate the mechanism for the decrease in ROS amounts, I measured RNA expression of genes that encode for the same antioxidant proteins studied in $\mathrm{T}$ cells and primary fibroblasts. I observed an increase in expression of $\operatorname{Prdx} 6$ in $\operatorname{Prdx} 1^{-/-}$cells but not in $\operatorname{Prdx} \mathrm{I}^{+/+}$cells after treatment with different dosages of $\mathrm{H}_{2} \mathrm{O}_{2}$ (Figure 2.6). 

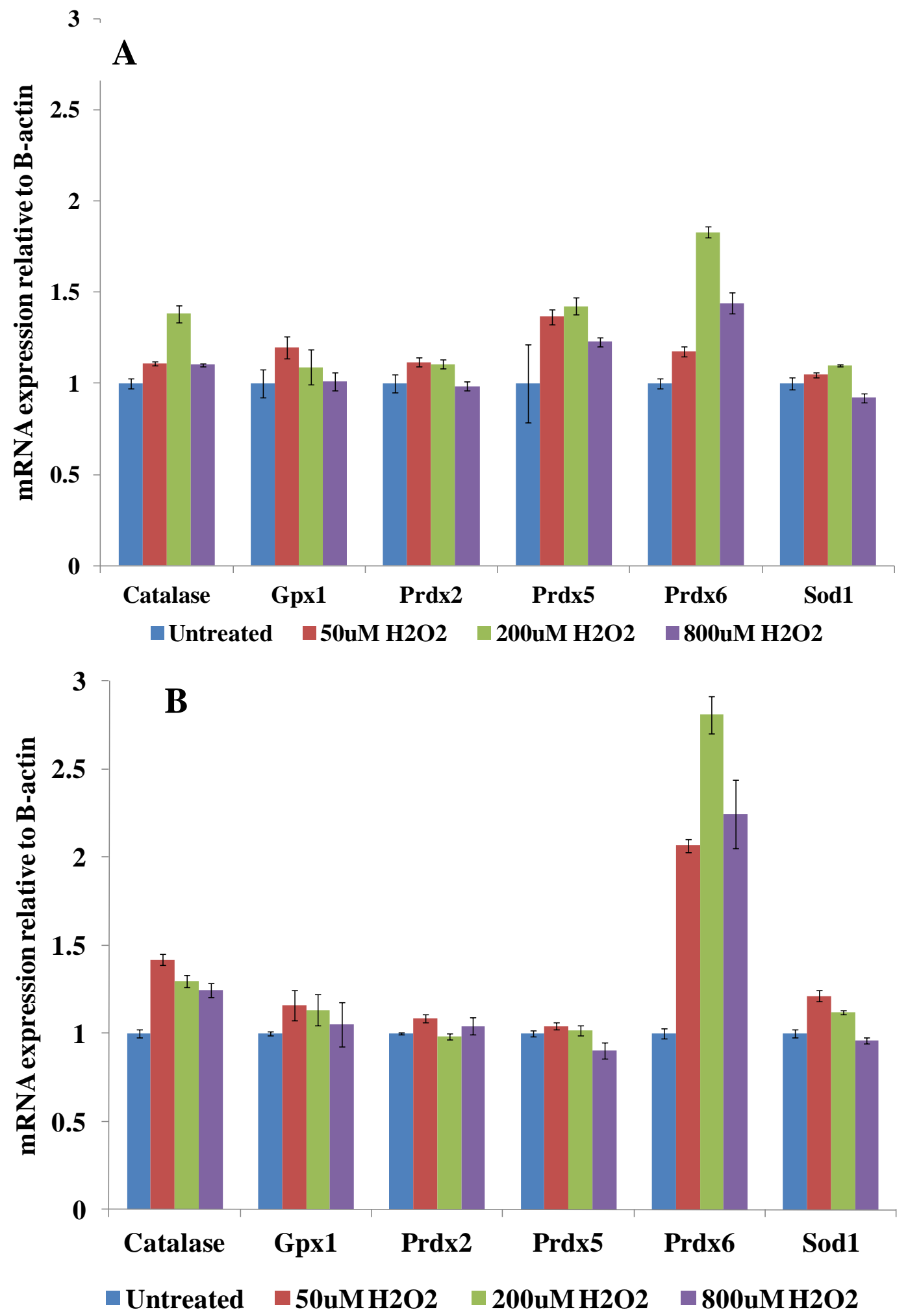

Figure 2.6. RNA expression of important antioxidant proteins after treatment with different dosages of $\mathrm{H}_{2} \mathrm{O}_{2}$ in A) $P r d x I^{+/+}$and B) $P r d x 1^{-/-}$cultured fibroblasts. All untreated samples were normalized to 1 . 
$\underline{\text { Decreased cell survival with } \mathrm{H}_{2} \underline{\mathrm{O}}_{2} \text { treatment in fibroblasts with the loss of Prdx } 1}$

A change in the amount of intracellular ROS is considered to be directly correlated with increased cell death. Therefore, I looked at cell survival after $\mathrm{H}_{2} \mathrm{O}_{2}$ treatment and surprisingly, found no clear direct correlation between extent of ROS amounts and cell survival. The survival of $\operatorname{Prdx} 1^{-/-}$cells was lower in comparison to

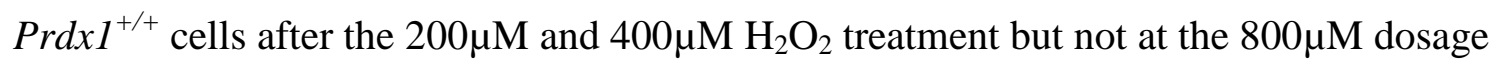
(Figure 2.7).

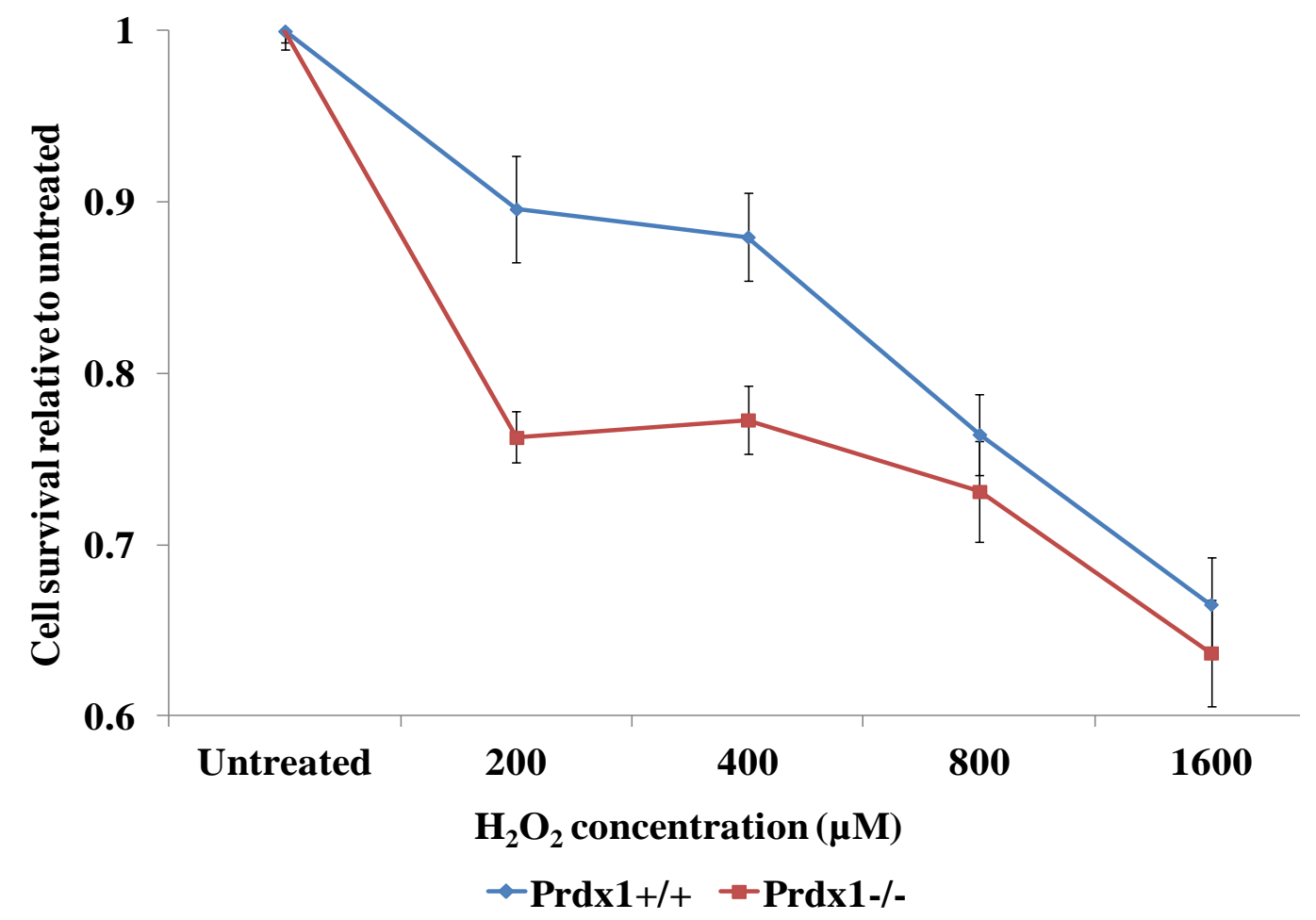

Figure 2.7. Cell survival in $\mathrm{PrdxI} \mathrm{I}^{+/+}$and $\mathrm{Prdx1^{-/ }}$ cultured fibroblasts with $1 \mathrm{Hr}$ treatment of $\mathrm{H}_{2} \mathrm{O}_{2}$ and recover for 24 hours. Untreated samples were normalized to 1.

Additionally, it could be extrapolated from the graph that survival after $50 \mu \mathrm{M} \mathrm{H}_{2} \mathrm{O}_{2}$

would be lower in $\operatorname{Prdx} 1^{-/-}$cells in comparison to $\operatorname{Prdx} 1^{+/+}$cells even though no measured changes in ROS amounts were observed (Figure 2.5). This suggests that a change in overall intracellular ROS amounts is not the primary factor in determining the extent of cell death. 


\subsection{Discussion}

As observed previously in MEFs, ROS amounts were significantly increased in fibroblasts and T cells of $\operatorname{Prdx1^{-/}}$ mice. The ROS amounts in fibroblasts were higher than in T cells, which could be due to differences in $\operatorname{Prdx} 1$ peroxidase activity between the cell types. Fibroblasts tended to have a reduced Prdx1 activity when compared to T cells, as evidenced by the greater formation of Prdx1 oligomers, monomers and the reduced formation of Prdx 1 dimers in fibroblasts than in T cells across all dosages of $\mathrm{H}_{2} \mathrm{O}_{2}$ (Figure 2.2). It has been shown that the extent of $\operatorname{Prdx} 1$ dimer formation is directly correlative to its catalytic activity. This is due to the fact that the $\operatorname{Prdx} 1$ catalytic cycle involves the formation of a disulfide bridge between the oxidized $\mathrm{NH}_{2}$-terminal $\mathrm{Cys}^{51}$ $\mathrm{SOH}$ on one monomer with the $\mathrm{COOH}$-terminal $\mathrm{Cys}^{172}$-SH on the other monomer, resulting in dimer formation (Jeong et al., 2006). The cycle is completed with the reduction of the cysteines to $-\mathrm{SH}$ by thioredoxin (Trx) (Wood et al., 2003). However, prior to the formation of the disulfide bridge between $\mathrm{Cys}^{51}$ and $\mathrm{Cys}^{172}$, $\mathrm{Cys}^{51}$-SOH could be further oxidized to $\mathrm{Cys}^{51}-\mathrm{SO}_{2} \mathrm{H}$. The further-oxidized Cys ${ }^{51}$ cannot bond with Cys ${ }^{172}$ SH (Yang et al., 2002) and thus results in inactivation of Prdx 1 activity. In order to minimize this inactivation, cells have a sulfiredoxin protein that reduces $\mathrm{Cys}^{51}-\mathrm{SO}_{2} \mathrm{H}$ to Cys $^{51}$-SOH (Jeong et al., 2006). Therefore, we hypothesize that the activity of sulfiredoxin is probably lower in fibroblasts in comparison to T cells. Another possibility is decreased thioredoxin (Trx) enzyme activity in T cells compared to fibroblasts. Recently it has been described that the extent of $\mathrm{H}_{2} \mathrm{O}_{2}$-induced overoxidation of the $\mathrm{Prdx}$ catalytic cysteine is directly correlated with thioredoxin activity. It is therefore likely that over-oxidation of the catalytic Prdx cysteine occurs during catalysis by binding of Trx to 
Prdx-disulfides, where the reduction process renders the reduced $\mathrm{Cys}^{51}$-SH to destabilization and over-oxidation in the presence of $\mathrm{H}_{2} \mathrm{O}_{2}$, by inhibiting the "sequestration" of reduced Cys ${ }^{51}$ in the active-site pocket (Yang KS et al., 2002). The observation of differences in the extent of Prdx1 dimer formation with increased $\mathrm{H}_{2} \mathrm{O}_{2}$ treatment is an indirect but probably an accurate observation of Prdx1 activity (Cao J et al., 2009). Nonetheless, to corroborate our findings, future studies would involve directly measuring $\operatorname{Prdx} 1$ activity in $\mathrm{H}_{2} \mathrm{O}_{2}$ treated fibroblasts and $\mathrm{T}$ cells by performing a Trx/Trx reductase (TrxR)/NADPH-coupled spectrophotometric assay as described (Chae et al., 1994). This assay measures the extracellular release of $\mathrm{H}_{2} \mathrm{O}_{2}$, which is indirectly correlated to the amount of Prdx1 activity.

The elevated amounts of ROS in $\operatorname{Prdx} 1^{-/-}$T-cells and $\operatorname{Prd} x 1^{-/-}$ear fibroblasts were a direct consequence of reduced Prdx1 scavenging activity and not due to changes in expression of regulation of major antioxidant genes: catalase, glutathione peroxidase 1 (Gpx1), Prdx2, Prdx5, Prdx6 and Sod1. The loss of Pten in mouse embryonic fibroblasts (MEFs) leads to hyperactivation through phosphorylation of Akt, which phosphorylates and inactivates FoxO. This inactivation of FoxO would lead to repression of transcriptional expression of Prdx2, Prdx5, Prdx6 and Sod1 (Huo YY et al., 2008). However, since under conditions of low $\mathrm{H}_{2} \mathrm{O}_{2}$-induced cellular $\mathrm{ROS}$, Prdx 1 promotes Pten phosphatase activity (Cao J et al., 2009) and Pten controls the hyperactivation of Akt under those conditions and expression of Prdx2, Prdx5, Prdx6 and Sod1 unaffected. Overall, I have found that Prdx1 is an important non-redundant peroxidase in primary ear fibroblasts and $\mathrm{T}$ cells. 
The non-redundancy of Prdx 1 observed in T cells was not observed when examining $\operatorname{Prdx} 1^{-/}$whole spleen tissue, where there was a compensation in expression of catalase, Gpx1, Prdx2 and Prdx6 (Figure 2.3). Gene expression of catalase and Prdx6 has been shown to be up-regulated by direct binding of the NF-E2-related factor-2 (Nrf2) transcription factor to their respective antioxidant response element (ARE) promoter regions (Chowdhury I et al., 2009; Lee JM et al., 2003). Nrf2 is normally repressed in the cytoplasm by Kelch-like ECH-associated protein 1 (Keap1), but translocates to the nucleus with elevated intracellular oxidative stress (Itoh K et al., 1999; Lee JM et al., 2003). In the case of Prdx6, Nrf2 binds directly to its ARE promoter region, leading to up-regulation of its expression in human epithelial cells that were treated with $\mathrm{H}_{2} \mathrm{O}_{2}$ (Chowdhury I et al., 2009). For catalase, the mechanism of its up-regulation is currently unclear (Lee JM et al., 2003). It is also possible that the induction in expression of Gpx 1 and Prdx2 is regulated by Nrf2 as other family members of each of the respective genes (Prdx1 and Gpx4) have been found to be up-regulated by Nrf2 (Lee JM et al., 2003; Kim YJ et al., 2007). The compensation in expression by catalase, Gpx1, Prdx2 and Prdx6 with the loss of Prdx 1 are novel findings, as currently, the only gene known to be upregulated with the loss of Prdx 1 is Prdx5 in MEFs (Graves JA et al., 2009). This was a direct result of c-Myc direct binding to the promoter region of Prdx5. However, the upregulation of Prdx5 expression was not observed in this study when examining the whole spleen tissue (Figure 2.4), T-cells or primary ear fibroblasts (Figure 2.3), suggesting that the c-Myc up-regulation of $\operatorname{Prdx} 5$ is a cell specific phenomenon.

The complexity of $\mathrm{H}_{2} \mathrm{O}_{2}$ scavenging in the absence of $\operatorname{Prdx} 1$ was made more apparent when cultured ear fibroblasts were treated with $\mathrm{H}_{2} \mathrm{O}_{2}$. As hypothesized, there 
was decreased survival after $\mathrm{H}_{2} \mathrm{O}_{2}$ treatment in $\operatorname{Prdx} 1^{-/}$cells compared to $\operatorname{Prdx} 1^{+/+}$cells (Figure 2.7). However, this was not directly correlated to changes in the overall intracellular amounts of ROS (Figure 2.6) as they were lower in both $\operatorname{Prdx} 1^{-/}$and $\operatorname{Prdx1^{+/+}}$ cells with no difference between them. A possible explanation for this discrepancy could be due to the differences in localization of ROS between $\operatorname{Prdx} 1^{-/-}$and $\operatorname{Prdx} 1^{+/+}$cells. It has been previously observed that the loss of Prdx 1 in MEFs led to greater nuclear localization of ROS compared to $\operatorname{Prdxl}^{+/+}$MEFs (Egler RA et al., 2005). Thus, it is possible that ROS is mainly sequestered to the nucleus in the $\operatorname{Prdx} 1^{-/}$ fibroblasts treated with $\mathrm{H}_{2} \mathrm{O}_{2}$ with reduced amounts of ROS elsewhere in the cell, producing the observed average value for the entire cell. The greater sequestration to the nucleus could promote DNA damage that could activate the pro-apoptotic machinery. Furthermore, the significant induction of Prdx6 expression in $\operatorname{Prdx} 1^{-/}$cultured fibroblasts but not in $\operatorname{Prdx} 1^{+/+}$cultured fibroblasts suggests a different underlying mechanism for the decreased ROS amounts after $\mathrm{H}_{2} \mathrm{O}_{2}$ treatment. As previously noted, the induction in Prdx6 gene expression was due to greater binding of Nrf2 to its ARE promoter region (Chowdhury I et al., 2009). Therefore, in a future study, immunocytochemistry analyses would be done to determine if there is a differential localization of the Nrf2 protein in untreated and $\mathrm{H}_{2} \mathrm{O}_{2}$ treated $\operatorname{Prdx} 1^{+/+}$and $\operatorname{Prdx} 1^{-/-}$fibroblasts. If there is greater translocation to the nucleus in $\mathrm{Prdxl}^{-/}$fibroblasts after $\mathrm{H}_{2} \mathrm{O}_{2}$ treatment, then chromatin immunoprecipitation (ChIP) could be done to determine if Nrf2 binds directly to the ARE promoter region of Prdx6. It is unclear why there was no induction in the expression of catalase as it is also up-regulated by Nrf2 (Lee JM et al., 2003). Nonetheless, the 
importance of Prdx1 as an intracellular $\mathrm{H}_{2} \mathrm{O}_{2}$ scavenger is complex and is highly cell and tissue specific. 


\section{Chapter 3}

\section{TISSUE SPECIFIC EFFECT OF LOSS OF PRDX1 ON LOH MUTANT FREQUENCY}

\subsection{Introduction}

Highly reactive ROS such as hydroxyl radicals $(\mathrm{OH} \bullet)$ and peroxynitrite $\left(\mathrm{ONOO}^{-}\right)$ radicals can interact with and damage DNA. The guanine nucleotide has a low redox potential making it easily oxidized and is hence considered an oxidative biomarker. The

other dNTPs are oxidized to a lesser extent. Increased oxidative DNA damage could also stem from compromised ROS scavenging such as in the case of Prdx 1 deficient mouse embryonic fibroblasts (MEFs) that had an elevated number of 8-oxoguanine (8-oxoG) DNA lesions mediated by increased oxidative stress (Neumann C et al., 2003).

Furthermore, a separate study of adult $\operatorname{Prdx} 1^{-/}$mice found increased amounts of different types of oxidative DNA lesions (8-oxoG, 8-oxoadenine (8-oxoA), (5'S)-cdA, (5'R)-cdG and (5'S)-cdG) in cells isolated from the spleen, the liver and the brain (Egler RA et al., 2005). The (5'R) and (5'S) cdG/A (8,5'-cyclo-2'-deoxyguanosine/ adenosine) lesions are lesions that distort DNA double helices, block DNA polymerases and inhibit transcription (Jaruga P \& Dizdaroglu, 2008).

In addition to the formation of base pair and helix distorting lesions, exposure of cells to an exogenous oxidative stressor also promotes the formation of DSBs, requiring repair through homologous recombination (HR), non-homologous end-joining (NHEJ) or single strand annealing (SSA) (Prise KM et al., 1989; Dahm-Daphi J, 2000; FrankenbergSchawager M et al., 2008). One of the consequences of DSB repair is loss of 
heterozygosity ( $\mathrm{LOH})$, if the DSB occurs proximally to a heterozygous locus. This was observed in vitro where two different cell types (Turker et al., 1999; Turner et al., 2003) treated with $\mathrm{H}_{2} \mathrm{O}_{2}$ led to significant elevation in $\mathrm{LOH}$ mutation frequency as a principal consequence of mitotic recombination (MR), a type of HR. The (Turner et al., 2003) study found that with increased dosages of $\mathrm{H}_{2} \mathrm{O}_{2}$ treatment, there was an increase in mitotic (MR) and in gene deletion events but not in intragenic mutation events at the HLA-A locus in human T-lymphocytes. LOH is frequently a rate-limiting step in tumorigenesis (Knudson, 1971) and increased frequency of LOH mutations is positively correlated with increased cancer incidence. In order to determine whether $\mathrm{LOH}$ is elevated in vivo by increased amounts of ROS, we measured the spontaneous Aprt LOH mutant frequencies in ear fibroblasts and splenic T-cells of Prdx 1 deficient mice. There was only a significant elevation in Aprt LOH mutant frequencies found only in $\operatorname{PrdxI^{+/}}$ and $\operatorname{Prdx} 1^{-/-}$fibroblasts but not in $\operatorname{Pr} d x 1^{+/-}$and $\operatorname{Pr} d x 1^{-/-}$T cells. However, the majority of Aprt LOH mutations in both T-cells and fibroblasts were derived from MR events. 


\subsection{Materials and Methods}

\section{$\underline{\text { Fibroblast Aprt LOH studies }}$}

The isolation and the counting of ear fibroblasts from 3-4 month old $\left(\operatorname{Prdx} \mathrm{I}^{+/+}\right.$, $\operatorname{PrdxI}^{+/-}$and $\operatorname{Prdx1^{-/}}$ ) Aprt ${ }^{+/-}$129XC57 hybrid mice for the Aprt LOH studies were as described in Chapter 2. For the 2,6-diaminopurine resistance (DAPr) selection plates, DAP (Sigma Aldrich) was added at a final concentration of $50 \mu \mathrm{g} / \mathrm{mL}$ to the cells in fibroblast medium. At least 2 selection plates were made for each ear with $\sim 1-2 X 10^{6}$ cells plated per 100-mm tissue culture dish. These cells were grown for 10-11 days with fresh fibroblast medium containing 50 $\mathrm{g} / \mathrm{mL}$ DAP replaced 4-5 days after the initial plating. DAPr colonies, which are marked on the bottom of the dish, were isolated using metal rings. Prior to placement of clonal rings, medium was aspirated and the plate was washed once with $1 \mathrm{X}$ PBS. One to two drops of $0.25 \%$ Trypsin-EDTA (Gibco) was added to each clonal ring and incubated at room temp for $\sim 3$ minutes. The fibroblast medium was then added to the ring, which was pipetted up and down with a micropipette in order to resuspend the cells. Each colony was placed in to a separate well of a 24-well plate containing fibroblast medium with $50 \mu \mathrm{g} / \mathrm{mL}$ DAP. The cells were grown until about $\sim 70 \%$ confluency and then transferred to a 6 -well plate with fibroblast medium supplemented with DAP. When the cells in the 6-well plates reached a minimum $\sim 50 \%$ confluency, they were collected via trypsinization and placed in a $1.5 \mathrm{~mL}$ microcentrifuge tube, the tubes were spun down at 13,200 rpm for 2 minutes. The supernatant was aspirated and the cell pellet resuspended in $50 \mu \mathrm{L}$ T-digest mix and incubated at $55^{\circ} \mathrm{C}$

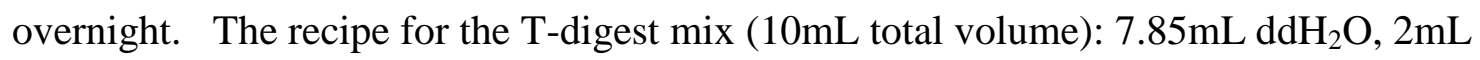


Colorless GoTaq ${ }^{\text {TM }} 5$ X reaction buffer, $100 \mu \mathrm{L}$ proteinase $\mathrm{K}(100 \mathrm{mg} / \mathrm{mL})$ (SigmaAldrich) and 50 $\mu \mathrm{L}$ of Tween-20 (Sigma-Aldrich).

To make the colony forming efficiency (CFE) plates, ear with the highest fibroblast cell count was irradiated at 6000 rads using the Torrex ${ }^{\circledR}$ Cabinet X-ray System (Faxitron X-ray LLC) and used as the feeder layer. Prior to irradiation, enough medium was added to the cells in the $50 \mathrm{~mL}$ tubes so that $2 \mathrm{~mL}$ of the feeder cells $\left(4-5 \times 10^{5}\right.$ cells $)$ can be added to each CFE plate (2 per ear). For each CFE plate, $2 \mathrm{~mL}$ of irradiated cells were added to $8 \mathrm{~mL}$ of fibroblast medium along with $\sim 10,000$ normal fibroblast cells in to $100-\mathrm{mm}$ tissue culture dishes (BD Biosciences) and incubated at $37^{\circ} \mathrm{C}-10 \% \mathrm{CO}_{2}-95 \%$ RH for 9-10 days. The CFE plates were scored 9 days after plating. This was done by removing the medium and adding $70 \%$ ethanol to each plate, which was kept for at least 20 minutes. The ethanol was then removed and 1:20 Giemsa (Sigma) diluted solution (in $\mathrm{H}_{2} \mathrm{O}$ ) was added to each plate and allowed to sit for $\sim 20$ minutes. The Giemsa solution was poured out and the plate was washed with water and allowed to dry overnight prior to scoring the plates. Colonies with at least 100 cells was marked as a positive colony. Each plate was counted and the average count of the 2 CFE plates was taken for each ear to represent the \# of CFE positive colonies for that respective ear.

\section{$\underline{\text { Splenic T cell Aprt LOH studies }}$}

The isolation and counting of $\mathrm{T}$ cells isolated from the spleen of 3-4 month old $\left(\operatorname{Prdxl}^{+/+}, \operatorname{Prdx}^{+/-}\right.$and $\left.\operatorname{Prdxl}^{-/}\right) \mathrm{Aprt}^{+/-}$129XC57 hybrid mice were as described in Chapter 2. For the $\mathrm{DAP}^{\mathrm{r}}$ selection plates (minimum 2 plates per spleen), the cells were diluted to a density of $2 \times 10^{5}$ cells $/ \mathrm{mL}, 142 \mu \mathrm{L}$ of this volume was separated and added to 
$5 \mathrm{~mL}$ of supplemented T-cell medium (recipe-Chapter 2) to be used for the CFE plates. After the cells were diluted, 2,6'-diaminopurine (DAP) was added at a final concentration of $50 \mu \mathrm{g} / \mathrm{mL}$ to supplemented medium in a $50 \mathrm{~mL}$ tube containing the cells. They were then transferred to a 50mL reservoir in order to be plated in 96-well round-bottom plates with the aid of a multichannel pipette. $100 \mu \mathrm{L}$ of the cells with medium supplemented with DAP ( 20,000 cells) were added to each well. The cells were incubated for 7-8 days prior to selection. Positive DAPr colonies were identified under an inverted microscope and the cell suspension collected using a micropipette. They were then spun down at 13,200 rpm for 2 minutes with supernatant aspirated and $30 \mu \mathrm{L}$ of T-digest mix added and incubated at $55^{\circ} \mathrm{C}$ for 2 hours and $98^{\circ} \mathrm{C}$ for 6 minutes.

In order to create the feeder layer needed for the 96-well colony forming efficiency (CFE) plates ( 2 for each spleen), the spleen with the high T cell count was used. Each CFE plate needed $1.5 \times 10^{6}$ irradiated cells at a density of $1.5 \times 10^{5}$ cells per $\mathrm{mL}$. Prior to irradiation, the T cells were transferred to $50 \mathrm{~mL}$ tubes with additional supplemented T-cell medium added to ensure enough volume existed for all of the plates ( $\sim 10 \mathrm{~mL}$ per CFE plate). The cells were irradiated in the same manner as the fibroblasts. For the CFE plates, the final volume of the feeder cells was divided in to $20 \mathrm{~mL}$ aliquots to which $142 \mu \mathrm{L}$ of the diluted normal T cells $\left(142 \mu \mathrm{L}\right.$ of T-cells $\left(2 \times 10^{5}\right.$ cells $\left./ \mathrm{mL}\right)$ in $5 \mathrm{~mL}$ of supplemented T-cell medium). They were then transferred to a $50 \mathrm{~mL}$ reservoir and $100 \mu \mathrm{L}$ was plated in each well of a 96-well plate using a multi-channel pipette. Each well had $\sim 15,000$ irradiated T cells and 4 non-irradiated splenic T cells. The CFE plates were incubated for 7-8 days prior to analyses. Positive CFE colonies were also identified 
using an inverted microscope. Some CFE colonies were also collected to be used as controls for Aprt classification analyses.

$\underline{\text { CFE and DAPr frequency calculations }}$

\section{Fibroblasts}

Colony forming efficiency (CFE) calculations for each ear:

$$
\mathrm{CFE}=\frac{\text { Average } \# \text { of CFE colonies }}{\# \text { of non }- \text { irradiated cells plated }}
$$

Frequency of fibroblast $\mathrm{DAP}^{\mathrm{r}}$ variants:

$$
\text { DAPr frequency }=\frac{\# \text { of DAPr colonies }}{\text { CFE X \# of cells plated for selection }}
$$

\section{T-cells}

CFE calculation:

$$
\mathrm{CFE}=\frac{-\ln (\text { negative CFE wells } / \text { total CFE wells })}{\# \text { of non }- \text { irradiated cells per well }(4 \text { cells })}
$$

Colony forming units (CFU)/well calculation:

CFU per well $=-\ln [($ negative selection wells $) /($ total selection wells $)]$

Frequency of T-cell DAPr variants calculation:

DAPr frequency

$$
=\frac{\text { CFU per well }}{(\# \text { of cells plated per well in DAPr selection plates }(20,000 \text { cells }) \times \text { CFE })}
$$

$\underline{\text { DAP }^{\mathrm{r}} \text { frequency statistical analyses }}$

Mann Whitney U-test (faculty.vassar.edu/lowry/utest.html) was utilized to

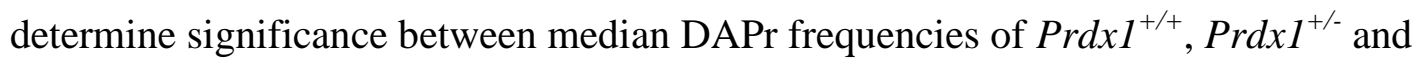
$\operatorname{Prdx1^{-/}}$ T-cells and ear fibroblasts. 


\section{$\underline{\text { Aprt mutant classification }}$}

Using the DNA extracted from the T cell and fibroblast colonies, we ran Aprt allele specific PCR to determine the classification of the Aprt mutation as class I (physical loss of WT allele) or class II (retained WT allele) with the REDExtract-N-Amp PCR Reaction Mix (Sigma-Aldrich). PCR recipe for Aprt classification:

\begin{tabular}{|l|l|}
\hline & Volume \\
\hline REDExtract Reaction Mix & $10 \mu \mathrm{L}$ \\
\hline S2 (100ng/uL) & $1 \mu \mathrm{L}$ \\
\hline Neo4 (100ng/uL) & $1 \mu \mathrm{L}$ \\
\hline MA009 (100ng/uL) & $0.5 \mu \mathrm{L}$ \\
\hline DNA & $1 \mu \mathrm{L}$ \\
\hline $\mathrm{ddH}_{2} \mathrm{O}$ & $6.5 \mu \mathrm{L}$ \\
\hline
\end{tabular}

The clones that were classified as class I mutants were further analyzed using microsatellite markers (D8Mit56,271, 106, 125 and 155) to determine if the mutants were derived from mitotic recombination (MR), gene conversion/interstitial deletion (GC/ID) or chromosomal loss (CL) events. Clones with LOH at loci distal to the Aprt allele (D8Mit125 and D8Mit155) but heterozygous proximal to the Aprt allele (D8Mit56 and D8Mit271) were considered to be derived from MR. Class I clones with LOH at both D8Mit56 (proximal to Aprt allele) and D8Mit155 (near centromere) were classified as originating from CL. Clones that did not exhibit LOH at D8Mit56 were classified as originating from GC or ID. PCR recipe for microsatellite marker analyses: 


\begin{tabular}{|l|l|}
\hline & Volume \\
\hline REDExtract Reaction Mix & $10 \mu \mathrm{L}$ \\
\hline D8MIT-Forward $(10 \mu \mathrm{M})$ & $1 \mu \mathrm{L}$ \\
\hline D8MIT-Reverse $(10 \mu \mathrm{M})$ & $1 \mu \mathrm{L}$ \\
\hline DNA & $1 \mu \mathrm{L}$ \\
\hline $\mathrm{ddH}_{2} \mathrm{O}$ & $7 \mu \mathrm{L}$ \\
\hline
\end{tabular}

The PCR conditions for Aprt LOH mutant classification and MSM analyses are the same as the conditions used for the tail DNA genotype analyses. 


\subsection{Results}

Increased LOH mutant frequency in ear fibroblasts of Prdx1 deficient mice

Given the significant increase in the amounts of ROS observed in $\operatorname{Prdx} 1^{-/}$

fibroblasts, I wanted to determine whether it led to significant elevation of in vivo LOH mutant frequency as reported in vitro (Turker et al., 1999; Turner et al., 2003).

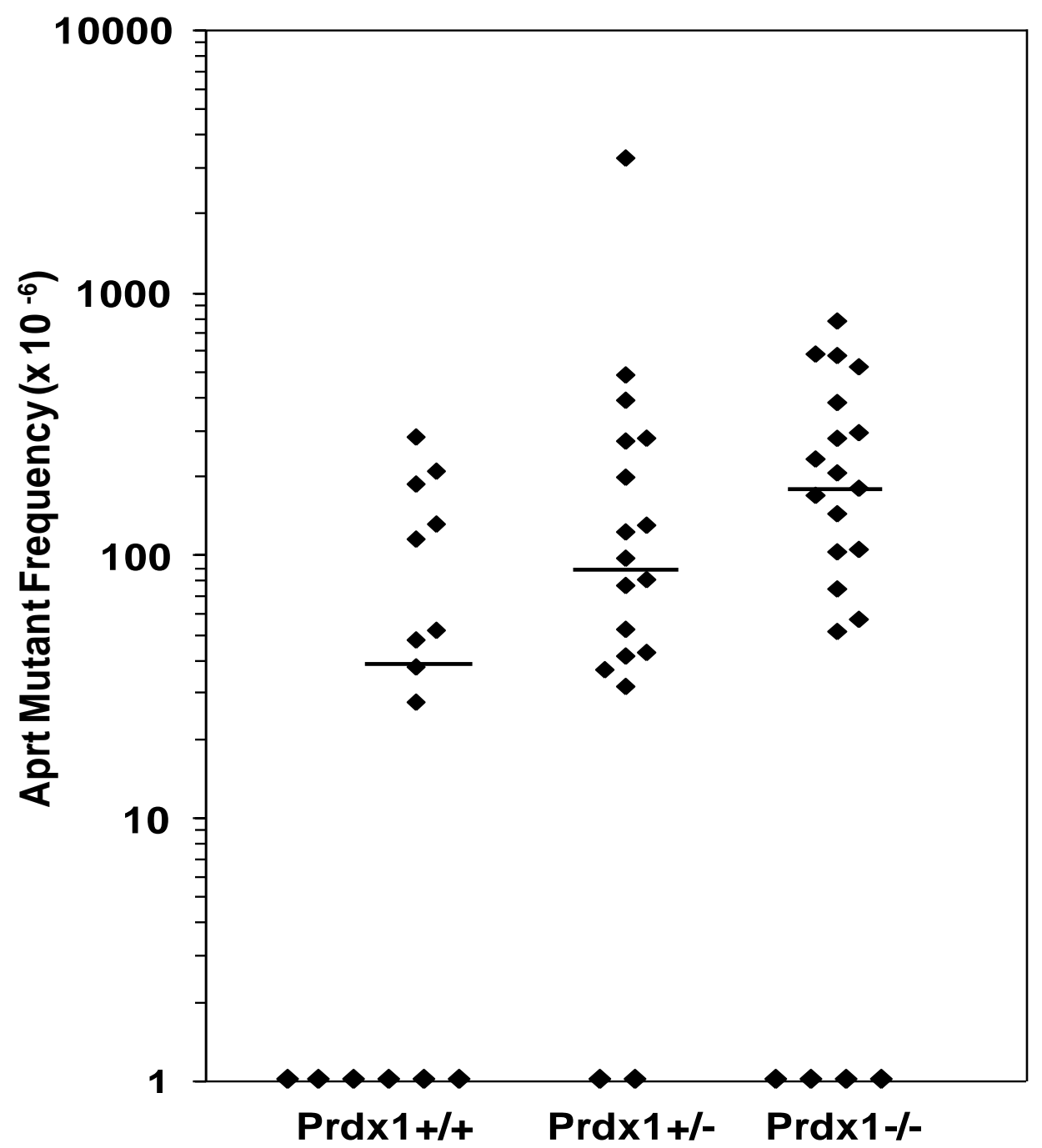

Figure 3.1. Frequency of DAP ${ }^{r}$ fibroblasts in individual mouse ears. Each point represents the frequency of DAP ${ }^{r}$ fibroblasts from one ear. The bars indicate median frequencies. Points at the $\mathrm{X}$-axis intersect represent fibroblasts from which no DAP $\mathrm{P}^{\mathrm{r}}$ colonies were recovered.

There was a significant elevation (4.5-fold; $\mathrm{p}=0.01)$ in Aprt $\mathrm{LOH}$ mutant frequency in fibroblasts of $\operatorname{Prdx1^{--}}$ mice compared to those of $\operatorname{Prdx} 1^{+/+}$mice (Figure 3.1 and Table 
3.1). Surprisingly, in $\operatorname{Prdx1^{+/-}}$ fibroblasts, there was also a significant elevation (2.3-fold; p=0.04) in Aprt LOH mutant frequency even though ROS amounts were not detected to be increased (Figure 2.1). The majority of Aprt LOH clones across all Prdx1 genotypes exhibited physical loss of the Aprt allele, designated as class I (Table 3.1). A representative gel image of the classification analyses on fibroblast clones (derived from $\operatorname{Prd} x 1^{+/}$and $\operatorname{Prdx} 1^{-/-}$mice) is illustrated in Figure 3.2. Samples \# 1-8 $\left(\operatorname{Pr} d x 1^{-/-}\right)$would be

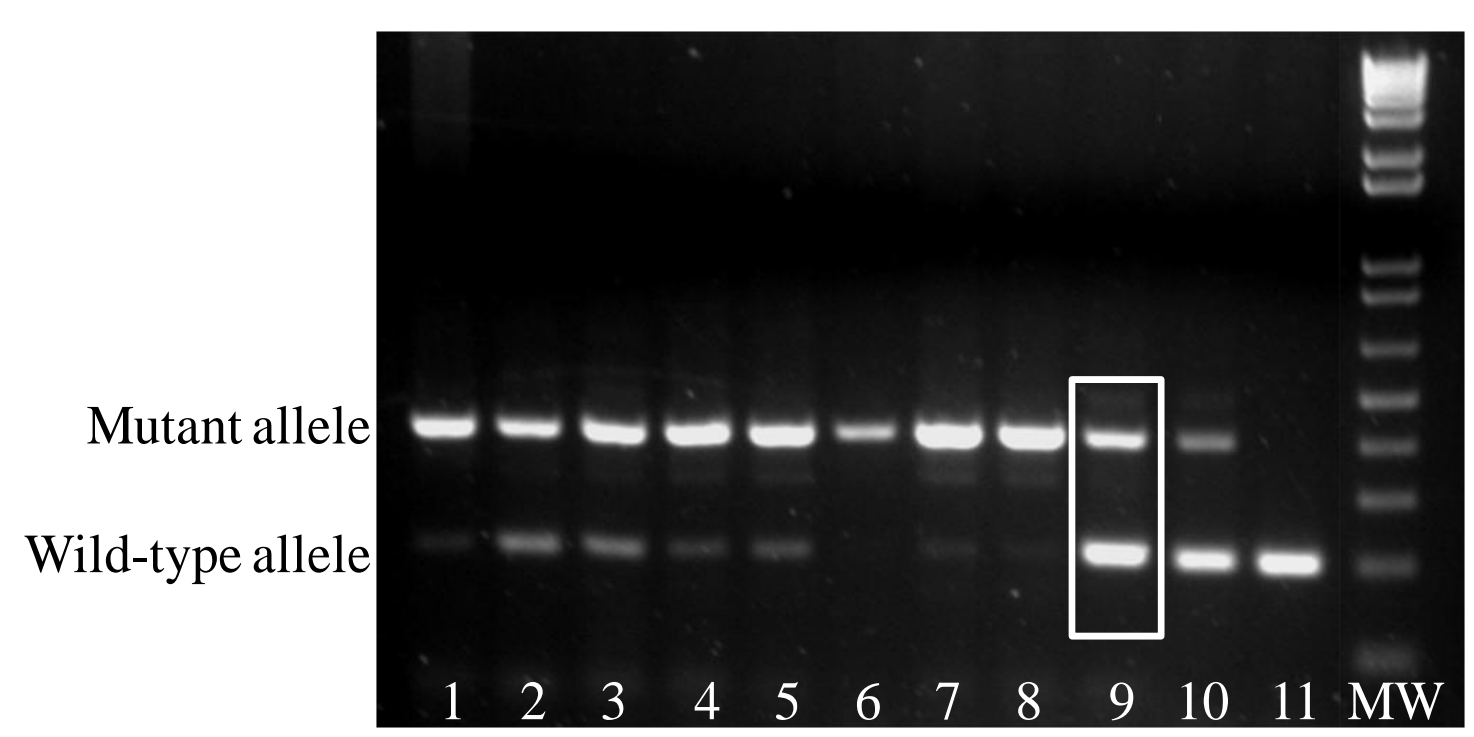

Figure 3.2. Representative gel image of fibroblast Aprt LOH clones from $\operatorname{Prdx} 1^{-/}$(\# 1-8) and $P r d x I^{+/-}$(\#9) mice. Samples\#10 and \#11 are $\mathrm{Aprt}^{+/-}$and $\mathrm{Aprt}^{+/+}$control DNA samples, respectively. Mutant Aprt allele is 398bp and wild-type Aprt allele is 198bp. 

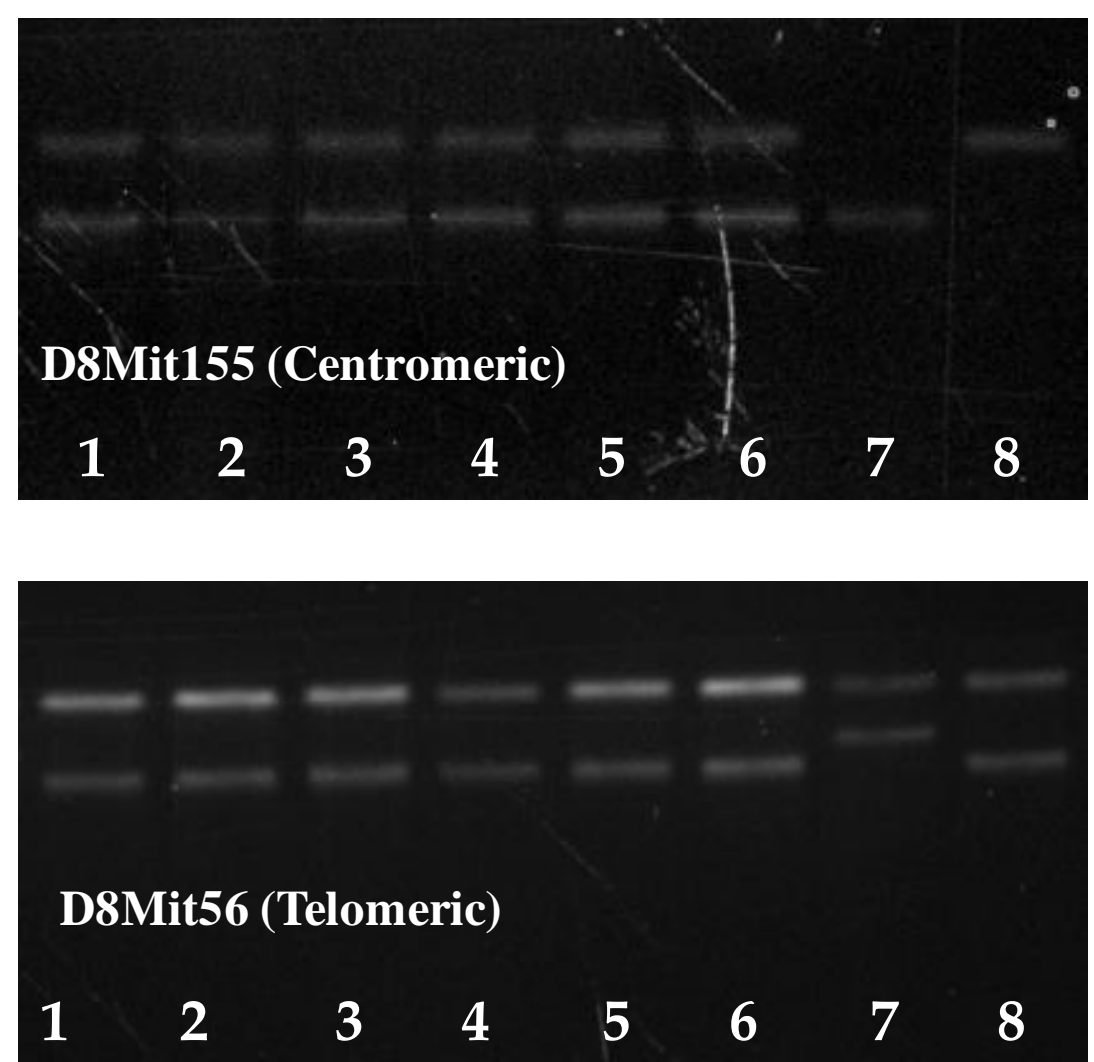

Figure 3.3. Representative gel image of MSM analyses of markers D8Mit56 and D8Mit155 from different fibroblast clones (1-6). Sample \#7 is the C57 strain control DNA and sample \#8 is the 129 strain control DNA.

classified as class I and sample \# $9\left(\operatorname{Prdxl^{+/}}\right)$ would be classified as class II. Samples \#10 and \#11 are $\mathrm{Aprt}^{+/-}$and $\mathrm{Aprt}^{+/+}$control DNA samples, respectively. Consistent with Aprt LOH spectrums in previous reports, class I clones were derived primarily from MR as determined by chromosome 8 microsatellite marker (MSM) analyses (Table 3.2). A representative gel image of this type of analyses is given in Figure 3.3. It illustrates the analyses of two different MSMs (D8Mit56 (telomeric) and D8Mit155 (centromeric)) on the same set of six fibroblast clones (1-6), with the last two samples in each set as the strain specific DNA controls(\#7-C57 strain and \#8-129 strain). All the clones in Figure 3.3 are considered to be derived from MR events. Overall, a small number of class I clones were derived from individual interstitial deletion/gene conversion (ID-GC) events in $\operatorname{Prdx1^{+-}}$ (4 clones) and $\operatorname{Prdx1^{-/}}$ (2 clones) fibroblasts, where each clone was 
independently derived from a different mouse. Additionally, six clones from one ear of a $\operatorname{Prd} x 1^{-/}$mouse exhibited LOH at all the marker loci tested (Table 3.2), suggesting that they may have been derived from chromosomal loss (CL). Because they were derived from a single mouse ear, they were probably sib clones.

\begin{tabular}{|c|c|c|c|c|c|c|c|}
\hline Genotype & $\begin{array}{c}\text { No. of } \\
\text { ears }\end{array}$ & $\begin{array}{l}\text { Cloning } \\
\text { efficiency \% } \\
\text { (mean } \pm \\
\text { s.e.) }\end{array}$ & $\begin{array}{c}D A P r \\
\text { frequency } \\
\left(\times 10^{-6}\right)^{a}\end{array}$ & $\begin{array}{c}\text { No. of } \\
\text { DAPr } \\
\text { colonies } \\
\text { analyzed }\end{array}$ & $\begin{array}{l}\text { No. of } \\
\text { class I } \\
\text { colonies }\end{array}$ & $\begin{array}{l}\text { \% class } \\
I \\
\text { colonies }\end{array}$ & $\begin{array}{l}\text { Class I } \\
\text { frequency } \\
\left(\times 10^{-6}\right)^{b}\end{array}$ \\
\hline $\operatorname{Prd} x 1^{+/+}$ & 15 & $1.29 \pm 0.07$ & 37.9 & 16 & 12 & 75 & 28.4 \\
\hline $\operatorname{Prd} x 1^{+/-}$ & 18 & $1.38 \pm 0.06$ & $89.3^{*}$ & 31 & 23 & 74 & 66.3 \\
\hline$\left.\operatorname{Prd} x\right|^{-/}$ & 21 & $1.26 \pm 0.05$ & $169^{*}$ & 53 & 42 & 79 & 134 \\
\hline
\end{tabular}

Table 3.1. Cloning efficiency, mutant frequency and classification of clones derived from ear fibroblasts. ${ }^{\mathrm{a}}$ Median frequency. ${ }^{\mathrm{b}}$ Calculated by multiplying DAPr frequency and $\%$ class I. ${ }^{*} \mathrm{p}<0.05$, Mann Whitney U-test

\begin{tabular}{|c|c|c|c|c|c|}
\hline Cell Type & Genotype & $\begin{array}{c}\text { Totalno. of } \\
\text { clones }\end{array}$ & $\begin{array}{c}\text { Mitotic } \\
\text { recombination }\end{array}$ & $\begin{array}{c}\text { Deletion or } \\
\text { gene } \\
\text { conversion }\end{array}$ & $\begin{array}{c}\text { Chromosomal } \\
\text { loss }\end{array}$ \\
\hline \multirow[t]{3}{*}{ Fibroblasts } & $\operatorname{Prdx} 1^{+/+}$ & 12 & 12 & 0 & 0 \\
\hline & $\operatorname{Prdx} 1^{+/-}$ & 23 & 19 & 4 & 0 \\
\hline & $\operatorname{Prdx} 1^{-/}$ & 42 & 35 & 1 & 6 \\
\hline \multirow[t]{3}{*}{ T-cells } & $\operatorname{Prdx} 1^{+/+}$ & 30 & 26 & 4 & 0 \\
\hline & $\operatorname{Prd} x 1^{+/-}$ & 27 & 24 & 3 & 0 \\
\hline & $\operatorname{Prd} x 1^{-/-}$ & 33 & 30 & 1 & 2 \\
\hline
\end{tabular}

Table 3.2. Mutational spectrum of class I clones in T-cells and fibroblasts. 
$\underline{\mathrm{LOH} \text { mutant frequency in T cells unaffected with loss of Prdx } 1}$

Unlike in fibroblasts, no change in Aprt LOH mutant frequency was observed in $\mathrm{T}$ cells with the loss of Prdx1 (Figure 3.4 and Table 3.3), although there was a significant elevation in the amounts of ROS in $\operatorname{Prd} x 1^{-/-}$T cells (Figure 2.1).

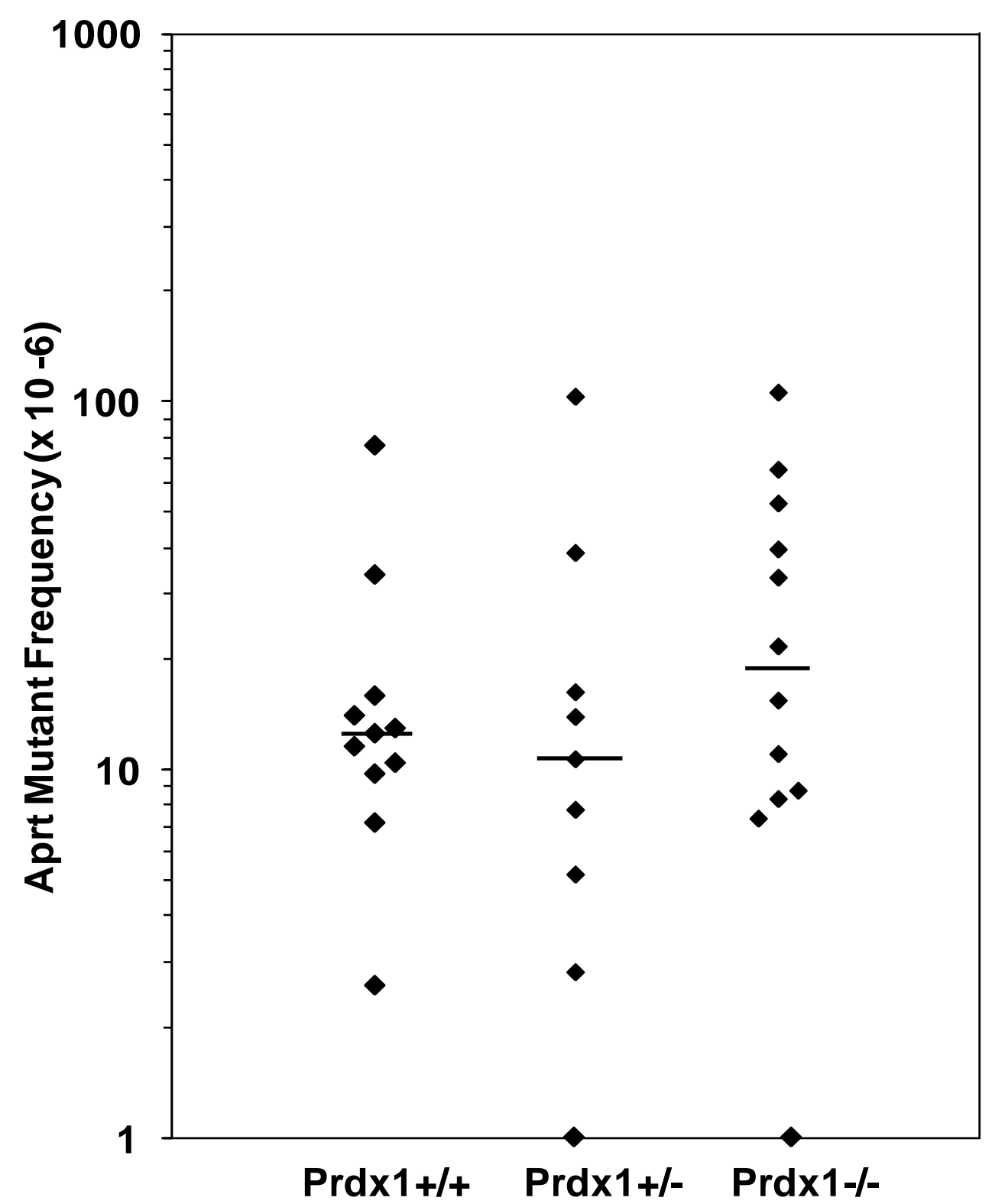

Figure 3.2. Frequency of $\mathrm{DAP}^{\mathrm{r}} \mathrm{T}$-cells from individual mouse spleens. Each point represents the frequency of $\mathrm{DAP}^{\mathrm{r}} \mathrm{T}$-cells from one spleen. The bars indicate median frequencies. Points at $\mathrm{x}$-axis intersect represent $\mathrm{T}$-cells from which no $\mathrm{DAP}^{\mathrm{r}}$ colonies were recovered. 
All three Prdx 1 genotypes exhibited a similar distribution of class I and class II Aprt LOH clones with a slight but insignificant increase in frequency of class I $\operatorname{Prd} d x 1^{-/}$clones (<2-fold) compared to $\operatorname{PrdxI^{+/+}}$ (Table 3.3). The majority of Aprt LOH class I clones were derived from MR events (85\% in $\operatorname{Prdx1^{+/+}}, 89 \%$ in $\operatorname{Prd} x 1^{+/-}$and $91 \%$ in $\operatorname{Prd} x 1^{-/}$). Interstitial deletion (ID) and gene conversion (GC) events were responsible for the remaining $\operatorname{Prdx} 1^{+/+}$(4 clones) and $\operatorname{Prdx1^{+/-}}$ (3 clones) class I Aprt LOH clones, each derived from a different spleen.

\begin{tabular}{|c|c|c|c|c|c|c|c|}
\hline Genotype & $\begin{array}{l}\text { No. of } \\
\text { mice }\end{array}$ & $\begin{array}{c}\text { Cloning } \\
\text { efficiency \% } \\
\text { (mean } \pm \\
\text { s.e.) }\end{array}$ & $\begin{array}{c}D A P r \\
\text { frequency } \\
\left(x 10^{-6}\right)^{a}\end{array}$ & $\begin{array}{c}\text { No. of } \\
\text { DAPr } \\
\text { colonies } \\
\text { analyzed }\end{array}$ & $\begin{array}{l}\text { No. of } \\
\text { class I } \\
\text { colonies }\end{array}$ & $\begin{array}{c}\text { \% class } \\
\text { I } \\
\text { colonies }\end{array}$ & $\begin{array}{c}\text { Class I } \\
\text { frequency } \\
\left(\times 10^{-6}\right)^{b}\end{array}$ \\
\hline $\operatorname{PrdxI^{+/+}}$ & 11 & $5.58 \pm 1.17$ & 11.6 & 33 & 27 & 82 & 9.5 \\
\hline PrdxI ${ }^{+/-}$ & 9 & $7.09 \pm 1.42$ & 10.7 & 34 & 27 & 79 & 8.5 \\
\hline $\operatorname{Prdx} 1^{\%-}$ & 12 & $4.21 \pm 1.01$ & 18.4 & 37 & 33 & 89 & 16.4 \\
\hline
\end{tabular}

Table 3.3. Cloning efficiency, mutant frequency and classification of clones derived from splenic T-cells. ${ }^{\mathrm{a}}$ Median frequency. ${ }^{\mathrm{b}}$ Calculated by multiplying DAPr frequency and $\%$ class I.

One $\operatorname{Prd} x \mathrm{I}^{-/}$class I Aprt LOH clone was derived from an ID-GC event and two clones exhibited LOH at all marker loci along the length of chromosome 8 (Table 3.2). Again, the two clones displaying whole chromosome $\mathrm{LOH}$ were derived from the same spleen and therefore, are considered sib clones. 


\subsection{Discussion}

This study was the first to explore the effect of ROS on LOH mutations in vivo. Previous studies (Turner et al., 2003; Turker et al., 1999) were able to induce LOH mutations in vitro with $\mathrm{H}_{2} \mathrm{O}_{2}$ treatment making a direct correlation between $\mathrm{ROS}$ exposure and frequency of mutations. However, in vivo, the connection is more complicated as witnessed by the tissue specific findings of this study. Nonetheless, as per the findings in vitro, majority of all Aprt LOH clones derived from both T-cells and fibroblasts were primarily derived from mitotic recombination (MR), a type of homologous recombination (HR), which seems to be a direct consequence of the need for double-strand break (DSB) repair. The study by (Moynahan ME \& Jasin M, 1997) showed that when a DSB was introduced in to one allele of the retinoblastoma $(R b)$ locus that it induced a several fold increase in allelic (mitotic) recombination events primarily resulting in $\mathrm{LOH}$. It has been well documented that DSBs occur as a type of oxidative damage through the initial formation of SSBs that can form from base-pair damage such as 8-oxoguanine lesions that were not efficiently repaired by base excision repair (BER) (Dahm-Daphi J et al., 2000; Frankenberg-Schawager M et al., 2008). Furthermore, the (Frankenberg-Schawager M et al., 2008) study found that mammalian cells in S-phase compared to cells in G1-phase are considerably more sensitive to the formation of DSBs induced by treatment with $\mathrm{H}_{2} \mathrm{O}_{2}$. It was hypothesized that the more open chromatin structure in S-phase makes DNA less protected against the attack by hydroxyl $(\mathrm{OH} \bullet)$ radicals. This suggests that HR repair of DSBs would be predominant over repair by NHEJ as NHEJ repair occurs primarily during the G1-phase. This could explain why the majority of the LOH mutants observed in $\operatorname{Prdx} 1^{-/-}$fibroblasts were derived as a 
consequence of MR a type of HR. Repair by NHEJ, which may result in deletion of nucleotides around the DSB site, could be responsible for the small number of clones derived from interstitial deletion-gene conversion (ID-GC) events.

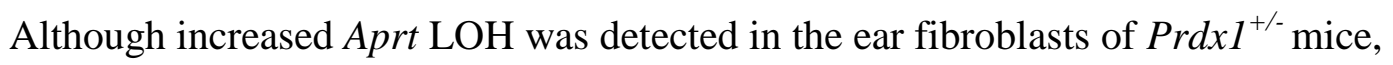
it was not accompanied by increased overall amounts of ROS. Thus, an increase in ROS amounts may not fully account for the increased LOH in fibroblasts of $\operatorname{Prdx1^{+/}}$ and $\operatorname{Prd} x 1^{-/-}$mice. It has been previously reported that $\operatorname{Pr} d x 1^{+/-}$MEFs had significantly increased Ras mediated transformation in comparison to $\operatorname{Prdx} 1^{+/+} \mathrm{MEFs}$, which was mediated by an increased activation of c-Myc (Egler et al., 2005). Activation of c-Myc in rat fibroblasts leads to loss of checkpoint response during G1/S, and consequently premature passage through G1 (Felsher and Bishop, 1999). Therefore, I speculate that increased c-Myc activation in $\operatorname{Prdx1^{+/}}$ fibroblasts led to a compromised G1 checkpoint response, accumulating cells in S-phase, which in turn produces more DSBs. In $\operatorname{PrdxI^{-/}}$ fibroblasts, the increased activation of c-Myc may act synergistically with increased ROS amounts to promote $\mathrm{LOH}$ mutations that are mediated by mitotic recombination (MR). Unlike our observations in $\operatorname{PrdxI^{-/}}$ fibroblasts, there was not a direct correlation between elevated ROS amounts and increased MR mediated LOH mutant frequency in $\operatorname{Prdx} 1^{-/-}$T cells. This disparity could be attributed to the much lower amounts of ROS in $\operatorname{Prdx1^{-/}}$ T cells relative to $\operatorname{Prdx} 1^{-/-}$fibroblasts; $\sim 4$-fold lower amounts of ROS were also observed in $\operatorname{Prdx} 1^{+/+}$T cells relative to $\operatorname{Prdx1^{+/+}}$ fibroblasts (Figure 2.1). It has been suggested that a certain threshold of the amounts of intracellular ROS must exist in order to significantly promote LOH (Turner et al., 2003). In that study, only the higher dosages of $\mathrm{H}_{2} \mathrm{O}_{2}$ treatment $(300-600 \mu \mathrm{M})$ led to a significant 2-6 fold increase in MR 
mediated LOH frequency while no increase in LOH frequency was observed with a $200 \mu \mathrm{M} \mathrm{H}_{2} \mathrm{O}_{2}$ treatment. The findings with the $200 \mu \mathrm{M} \mathrm{H}_{2} \mathrm{O}_{2}$ treatment could be analogous to what occurred in $\operatorname{Prdx1^{--}}$ T cells in this study. Additionally, other types of oxidative DNA lesions not recognized by our reporter assay could be promoted in $\mathrm{PrdxI}^{-}$ / splenic T cells. The number of helix distorting 8,5'cyclopurine-2'deoxynucleoside lesions has been shown to be elevated in splenocytes of $\operatorname{Prdx} \mathrm{T}^{-/}$mice (Egler et al., 2005). Therefore, it is possible that the number of these types of lesions could also be elevated in T cells. Finally, there could be tissue-specific differences in DNA repair with the loss of Prdxl that are crucial for repair of base pair lesions, single strand breaks (SSBs) and double strand breaks (DSBs). 


\section{Chapter 4 \\ THE EFFECT OF PRDX1 LOSS ON DNA REPAIR}

\subsection{Introduction}

Oxidative stress biomarkers such as 8-oxoguanine (8-oxoG) lesions have been used to determine the impact of ROS exposure on DNA damage. Therefore, repair of these types of lesions would be a primary line of defense to minimize damage to the DNA macromolecule. The first line of defense is the activation of 8-oxo-7,8dihydrodeoxyguanosine triphosphatase (8-oxo-dGTPase) (Mth1) that degrades 8-oxoGTP in the nucleotide pool to 8-oxo-GMP and pyrophosphate. However, the enzymatic activity of Mth1 is limited under high amounts of ROS and 8-oxo-GTP lesions are incorporated in to the DNA (Meyer F et al., 2000). Therefore, removal of 8-oxo-GTP lesions in DNA becomes necessary and is accomplished by base excision repair (BER).

The first step of BER is the recognition of the 8-oxo-GTP lesion by Ogg1 glycosylase, which excises the damaged DNA bases by cleaving the $\mathrm{N}$-glycosylic bond between 2'deoxyribose and the damaged base. This generates apurinic/apyrimidinic (AP) sites that are cleaved by 5'AP endonuclease (Apex) that leaves a 5'dRp (sugar phosphate) terminus. This is then removed by the dRp lyase activity of DNA polymerase (Pol) $\beta$, which results in a one nucleotide gap (short-patch). DNA polymerase $\beta$ also adds a new nucleotide, filling in the gap, which is ligated by the DNA ligase III-X-ray repair cross-complementing 1 (Xrcc1) complex (Fortini P \& Dogliotti E, 2007). In long-patch BER, the initial recognition and removal is the same as short patch BER. However, after cleavage of the AP sites, the 5'dRp cannot be removed by polymerase $\beta$ and strand 
displacement synthesis needs to occur with the aid of DNA polymerases delta $(\delta)$ and epsilon ( $\varepsilon$ ). As a result, a flap composed of the displaced oligonucleotide is created (van Loon B et al., 2010) and is excised by flap endonuclease 1 (Fen1) along with the 5'dRp (sugar phosphate) with final ligation by DNA ligase I. Oxidized pyrimidines such as thymine glycols (Tg), 5-hydroxyuracil, 5gG-dihydrouracil and 5-hydroxycytosine are also repaired by BER but through the use of Neil1 and Ung as glycosylases.

The efficient repair of base-pair DNA damage is important to prevent formation of single strand breaks (SSBs). A single strand break could occur as a result of a nick that is created by the DNA glycosylase and the AP endonuclease that is not filled in by DNA polymerase $\beta$ before the next round of replication. This has been evidenced in numerous different studies in cells that were treated with $\mathrm{H}_{2} \mathrm{O}_{2}$ (Cantoni $\mathrm{M}$ et al., 1989; Ward JF et al., 1985; Hoffman ME et al., 1984). Furthermore, SSBs that cannot be completely repaired before the arrival of advancing DNA replication complexes could generate double strand breaks (DSBs).

Double strand breaks (DSBs) are primarily repaired by homologous recombination (HR) and non-homologous end joining (NHEJ), with the repair pathway chosen based on the phase of the cell cycle. NHEJ primarily functions during G1 when only a homologous chromosome is present, while HR is preferred during and after Sphase when a sister chromatid is available. HR is considered error-free while repair by NHEJ usually leads to gain or loss of several nucleotides.

For HR, DSB is initially recognized by MRN, a complex consisting of meiotic recombination 11 homolog (Mre11), Rad50 and nibrin (Nbs1). The DNA ends are then 
resected, which allows binding of replication protein A (Rpa), $\operatorname{Rad} 51$ and $\operatorname{Rad} 52$ to the single strand (ss) DNA tails. The ssDNA-protein filament searches for a homologous region in an intact DNA duplex and initiates pairing, which is facilitated by Rad54 (Downs JA et al., 2007). Afterwards, DNA synthesis occurs from the invading end of the damaged DNA, extending the repair region and forming a Holliday junction. This junction translocates along the DNA in a process mediated by a branch migration complex and is cleaved by a resolvase (Downs JA et al., 2007). The DNA ends are rejoined to yield intact duplex products.

In addition to base pair damage and strand breaks, highly reactive ROS also cause helix distorting lesions such as 8,5' cyclopurine-2'deoxynucleosides, which are repaired by nucleotide excision repair (NER). There are two types of NER: transcription-coupled repair (TCR) and global-genome repair (GGR). TCR is specific for transcriptionally active domains while GGR is for the overall genome (Pascucci B et al., 2011). In GGR, lesion is recognized by xeroderma pigmentosum $\mathrm{c}(\mathrm{Xpc})-\mathrm{Rad} 23 \mathrm{~b}$ and Uvb complexes and in TCR it is recognized by RNA polymerase II (Pol II). The subsequent repair process is the same for both GGR and TCR. Two helicases, xeroderma pigmentosum $b$ $(\mathrm{Xpb})$ and xeroderma pigmentosum $\mathrm{d}(\mathrm{Xpd})$ initiate the opening around the lesion, and the DNA around the damaged site is cleaved by the Xpg 3' nuclease and the Xpf-excision repair cross-complementing rodent repair deficiency, complementation group 1 (Ercc1) complex 5' nuclease (Pascucci B et al., 2011). Once the damaged oligonucleotide is removed, resynthesis occurs by a combination of the activities of proliferating cell nuclear antigen (PCNA), DNA polymerase delta $(\delta)$, DNA polymerase epsilon $(\varepsilon)$, and 
DNA ligase (Friedberg EC et al., 2005). All the different repair processes are required to minimize damage to DNA.

Even with the advent of the different repair processes, the loss of $\operatorname{Prdx} 1$ in different cells and tissues resulted in the formation of different types of oxidative DNA damage (Neumann C et al., 2003; Egler RA et al., 2005). Elevated DNA damage was directly mediated by increased ROS in $P r d x 1^{-/-}$MEFs (Neumann C et al., 2003) and this study showed that increased amounts of ROS in $\operatorname{Prdx} 1^{-/-}$fibroblasts directly correlated to an increased LOH mutant frequency. However, in certain tissues of $\operatorname{Prdxl^{-/}}$ mice, there was an increased number of base pair and helix distorting lesions without an elevation in the intracellular amounts of ROS (Egler RA et al., 2005). This was also true in this study where a significant increase in the amounts of ROS in $\operatorname{Prdx} 1^{-/} \mathrm{T}$ cells did not lead to a significant promotion of frequency of LOH mutations. I hypothesize that the tissue specific observations in this study and in previous studies could be due to changes in DNA repair with the loss of Prdx1. I tested this hypothesis by measuring transcription of genes involved in different repair pathways in splenic $\mathrm{T}$ cells and primary fibroblasts derived from 3-4 month old $\operatorname{PrdxI^{+/+}}$ and $\operatorname{Prdx} \mathrm{I}^{-/}$mice. To confirm if the findings in T cells is representative of the tissue (spleen) from which it was derived, DNA repair gene transcription was also measured in the whole spleen tissue of 6 month old $\operatorname{PrdxI}^{+/+}$and $\operatorname{Prd} x 1^{-/}$mice. 


\subsection{Materials and Methods}

Gene expression analyses of DNA repair pathways in T cells and primary fibroblasts

The RNA from splenic T cells and primary ears fibroblasts utilized for this analyses is the same as the one used for RNA expression analyses of the genes that encoded antioxidant proteins in Chapter 2. Additionally, the cDNA synthesis, the setup of the 96-well and the 384-well plates and the subsequent qRT-PCR data analyses is as described in Chapter 1. The following DNA repair genes were analyzed and they are separated below based on their respective DNA repair pathway:

BER pathway

\begin{tabular}{lll}
\hline Gene & Forward Primer & Reverse Primer \\
& & \\
\hline Apex1 & CAGTGCCCGCTAAAAGTCTCTT & GGCTGTTACCAGGACAAAGGAC \\
Apex2 & GTTTTGGACAGCTGGATGCT & GCGGCTGAAGCTGAAATAGGA \\
Fen1 & GAACATTCCTCTTCGCCGGTA & TGTCATTCTCACGGATGGCAC \\
Ligase 1 & GTTCCTGACCTGGATCGAATCA & GGATGAGCCAGCATTGGTTTAA \\
Ligase 3 & TGGATTCCGAGGTACTCCTGA & GACATTAGCATCCTGGAAAGCA \\
Neil1 & GCTGGAACTGTGTCACTTGGTG & AGGCTCGAAAGGCAGCAAA \\
Ogg1 & TGACTACGGCTGGCATCCTAA & CAGCATAAGGTCCCCACAGATT \\
Pol $\beta$ & CAGCGAGAAGGATGGAAAGGA & GCGTGCGCTCTCATGTTCTTA \\
Pol $\varepsilon$ & TCAAGCCCCCTATGACTCCTCT & ATACCACGGCACTTGAGGCAT \\
Xrcc1 1 & CGAAAATCTTCTCAAGGCGGA & GGATCTGCTCCTCCTTCTCCAA \\
\hline
\end{tabular}

NER pathway

\begin{tabular}{lll}
\hline Gene & Forward Primer & Reverse Primer \\
& & \\
\hline Ddb1 & TCCATATTCGCACAGTTCCCC & GCTATCTTGGACTTCAATGCGG \\
Ercc1 & CGGTGAGGTGATTCCCGATTA & TGCAGCCGTTCATGGATGTAG \\
Xpa & AGAACCCACGCCATTCACAGT & TTGCATCTTCCAGAGCTTCCTG \\
Xpb & ATGGAGTGGCTCAAAACCCAG & GCCTGCACAATAGTCAGAACCC \\
Xpc & CTCTCCATCATTCCAATTCGCT & TGACAGTGAAGGTTCCGATGAA \\
Xpd & ATTGAGCCCTTTGACGACAGG & TGATGATGACAGACTGGAAGCG \\
Xpf & GCCATTCAGACGGCCATACTAG & ATGGCTTCCCAAGAGCGTTT \\
\hline
\end{tabular}

DSB repair

Gene Forward Primer Reverse Primer

Rad51 AGCGTCAGCCATGATGGTAGAA $\quad$ TTTGCCTGGCTGAAAGCTCTC




\begin{tabular}{lll}
\multicolumn{2}{l}{ Mismatch repair } & Reverse Primer \\
\hline Gene & Forward Primer & \\
\hline Mlh1 & CGGCCAATGCTATCAAAGAGA & CCAGTGCCATTGTCTTGGATC \\
\hline
\end{tabular}

Gene expression analyses of different DNA repair pathways in whole spleen tissue

The expression of genes involved in base excision repair (BER) and nucleotide excision repair (NER) were also analyzed in whole spleen tissue of 6 month old $\operatorname{Prdx} \mathrm{I}^{+/+}$ and $\operatorname{Prd} x 1^{--}$mice. The setup and subsequent analyses was as described in Chapter 2. Glyceraldehyde-3-phosphate dehydrogenase (GAPDH) was used as the loading control.

$\underline{\text { Statistical analyses }}$

Student t-test using Microsoft Excel was done to determine significance of gene expression changes with $\geq 2$-fold change and $\mathrm{p}<0.05$ considered significant. 


\subsection{Results}

Expression of Mlh1 in $\operatorname{Prdx}^{-/-}$T-cells and fibroblasts

As previously noted in Chapter 2, $\operatorname{Prdx} 1$ protein protects the phosphatase activity of Pten by minimizing the over-oxidation of the phosphatase and tensin homolog (Pten) protein (Cao X et al., 2009). Pten has been shown to be required for maintaining chromosomal stability and regulating transcription of Rad51 (Shen WH et al., 2007). Also, we previously showed that Mlh1-deficient mouse ear fibroblasts had an increased frequency of LOH mutants derived from MR (Shao et al., 2004). Therefore, we looked at changes in transcriptional expression of Rad51 and Mlh1. In both T cells and fibroblasts, the loss of Prdx1 had no significant effect on Rad51 expression (Figure 4.1).

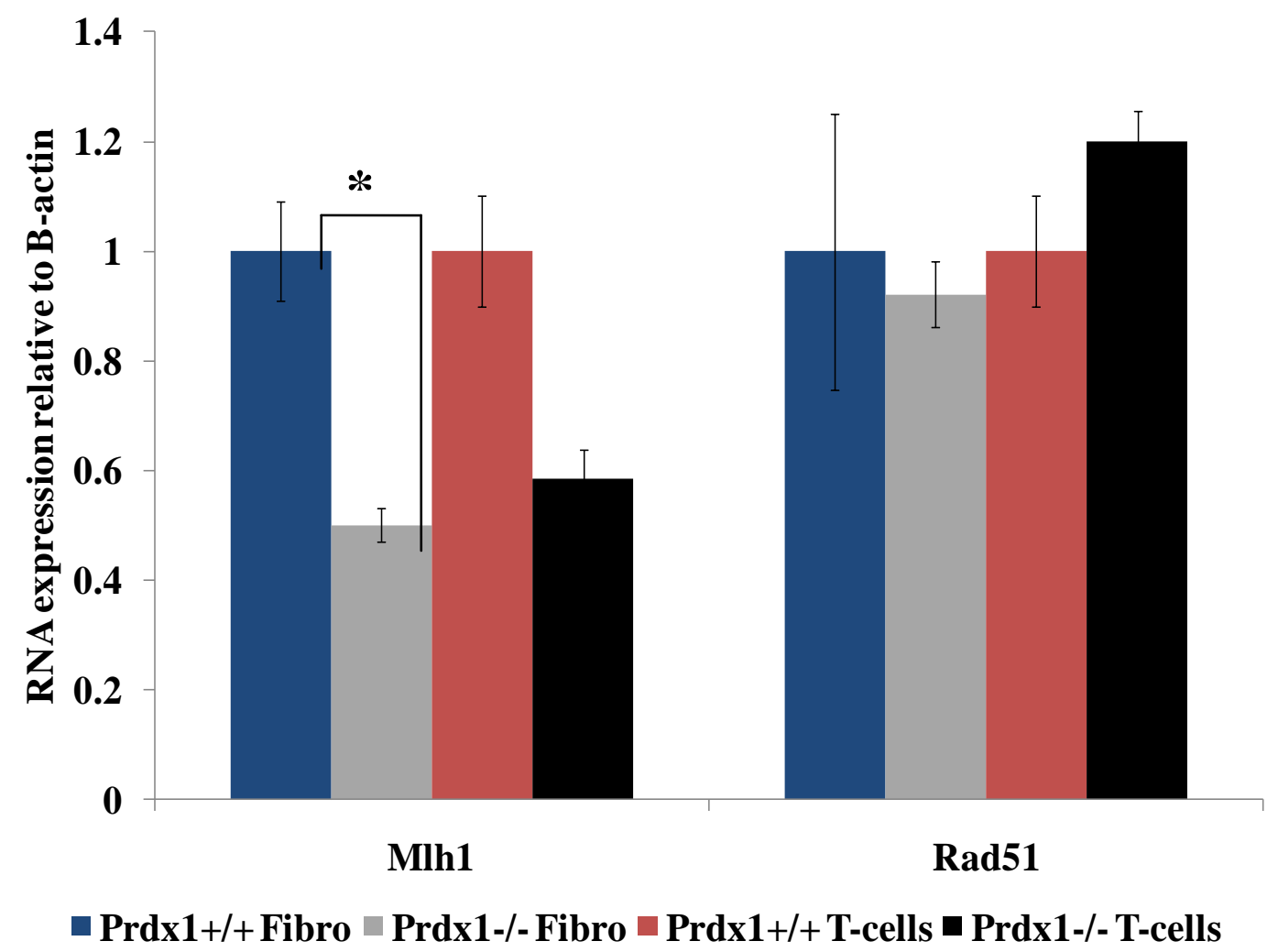

Figure 4.1. Relative mRNA expression of Mlh1 and Rad51 in $\operatorname{PrdxI^{+/+}}$ and $\operatorname{Prdx} 1^{-/-}$T-cells and fibroblasts. $* \geq 2$-fold change and $\mathrm{p}<0.05$. All $\operatorname{Prdx1^{+/+}}$ samples were normalized to 1 . 
However, we found a significant 2-fold reduction in $M l h 1$ expression in $\operatorname{Prdx} 1^{-/-}$ fibroblasts and a slightly less reduction in $\operatorname{Prdx} 1^{-/-}$T cells (1.7-fold-Figure 4.1). The decrease in Mlh1 expression could contribute to the increased frequency of LOH mutants in Prdx1-deficient fibroblasts.

$\underline{\text { Base excision repair gene expression unaffected in } \operatorname{Prdx} 1^{-/} \text {cells }}$

In addition to measuring expression of genes that could directly mediate mitotic recombination (MR), a type of homologous recombination, I also measured RNA expression of genes involved in base excision repair (BER). Compromised BER at the nucleotide synthesis and ligation steps could promote formation of single strand breaks (SSBs) that can mature in to DSBs during replication. This would promote the need for repair by recombination and hence act as a contributing factor in the promotion of $\mathrm{LOH}$ mutations in the absence of Prdx1. In $\operatorname{Prdx} 1^{-/-} \mathrm{T}$ cells and fibroblasts, there were no significant changes in expression of genes involved in nucleotide synthesis and ligation (Ligase 3, Xrcc1, Polymerase beta $(\beta)$ and polymerase epsilon $(\varepsilon)$ ). The expression of the glycosylases, Ogg1 and Neil1, involved in recognition and removal of oxidative DNA lesions was also unaffected as were the endonucleases, Apex1 and Apex2. Expression of the long patch BER endonuclease, Fen1, was also unaffected with the loss of Prdx1. 

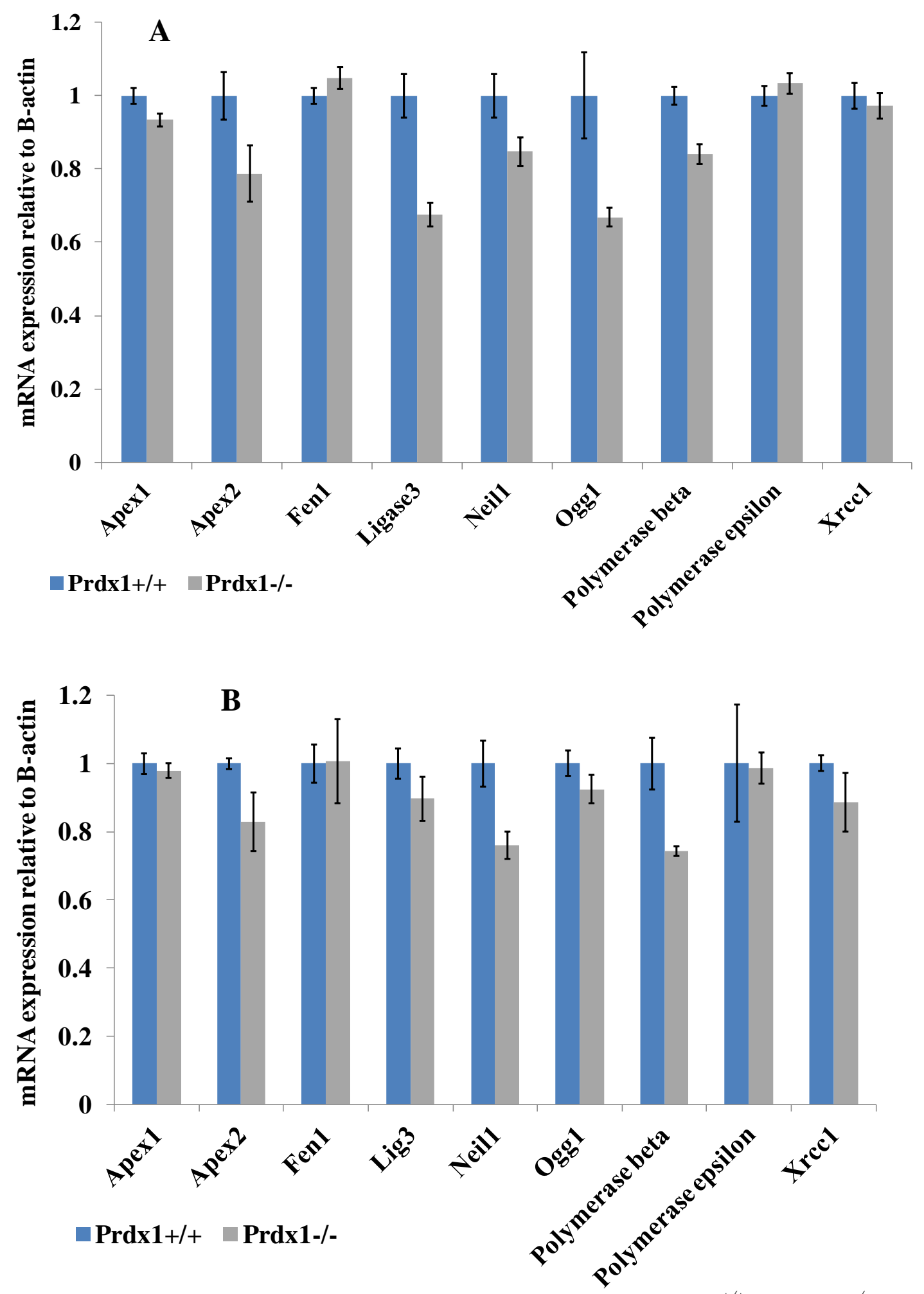

Figure 4.2. RNA expression of BER DNA repair pathway genes in $\operatorname{Pr} d x 1^{+/+}$and $\operatorname{Prdx1^{-/}}$ A) Tcells and B) primary ear fibroblasts. Expression of $\operatorname{Prdx} 1^{+/+}$samples was normalized to 1 . 
Induction of expression of genes involved in long-patch BER in $\operatorname{Prdx1^{-/}}$ spleen tissue

To understand if the findings in T cells were representative of the overall spleen from which it was derived, I looked at tissue wide transcription of the same BER genes (Figure 4.3). Similar to T-cells, no changes in expression of genes directly involved with short-patch BER were observed: Apex1, Apex2, Polymerase beta, Ligase 3 and Xrcc1. However, there was a significant increase in the RNA expression of three genes involved in long-patch BER: Fen1 (2.7-fold), Ligase 1 (2.2-fold) and Polymerase epsilon (2.5fold) (Figure 4.3).

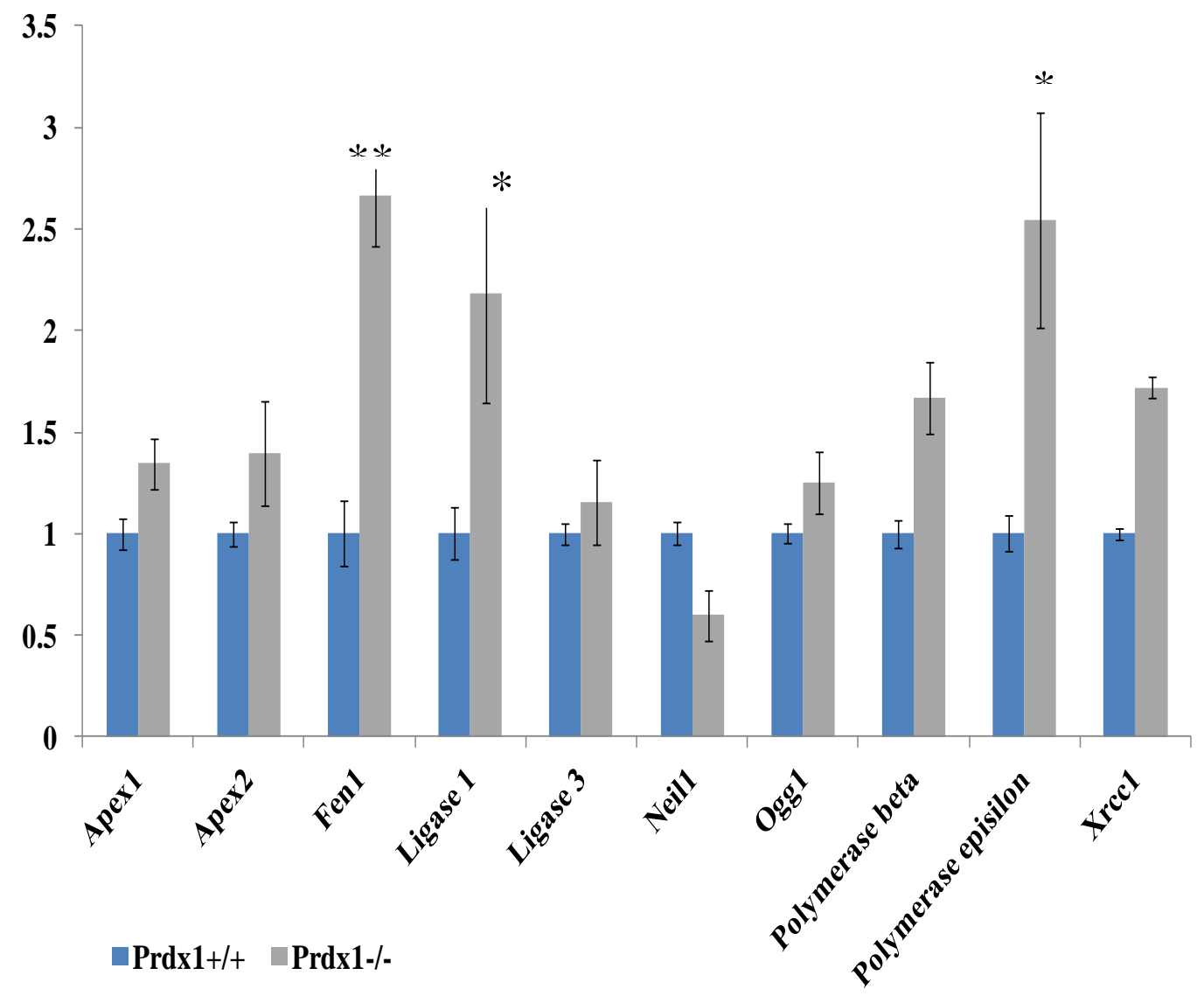

Figure 4.3. RNA expression of BER pathway genes in $\operatorname{Prdx} 1^{+/+}$and $\operatorname{Prd} d x 1^{-/-}$whole spleen tissue. Expression of $\operatorname{Prdx} 1^{+/+}$samples normalized to $1 . * \mathrm{p}<0.05, * * \mathrm{p}<0.01$

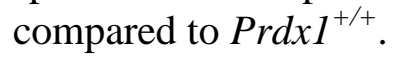


$\underline{\text { Down-regulation of Ercc1 in } \operatorname{Prdx} 1^{-/-} \text {T-cells and fibroblasts }}$

As previously noted, the study by (Egler RA et al., 2005) found elevated number of different helix distorting lesions in cells isolated from brain, spleen and liver tissues of $\operatorname{Prdx} 1^{-/-}$mice without an increase in ROS amounts. They hypothesized that it could be due to deficiencies in nucleotide excision repair (NER).

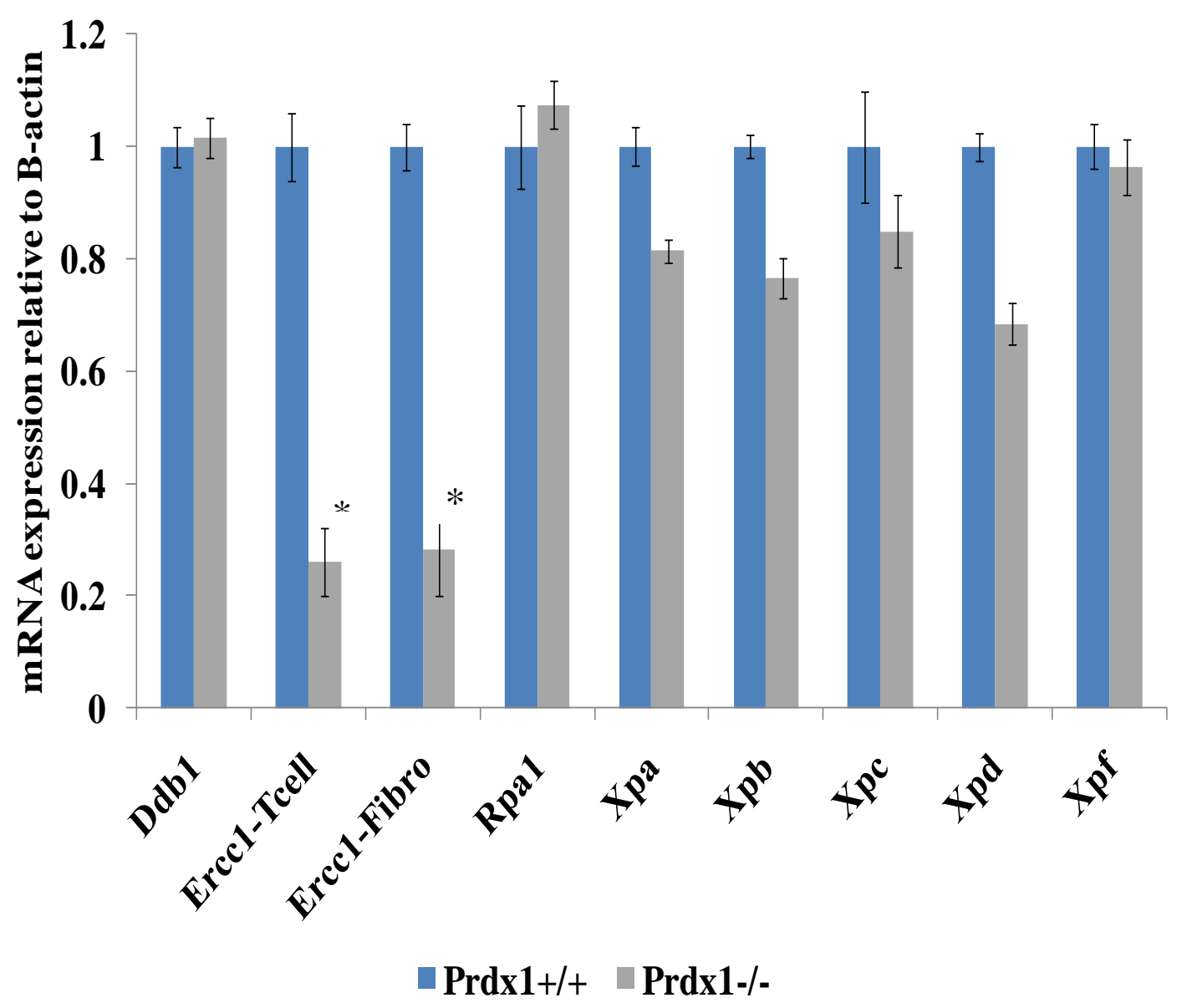

Figure 4.4. RNA expression of NER pathway genes in $\operatorname{Pr} d x 1^{+/+}$and $\operatorname{Prdx} 1^{-/-}$T-cells and Ercc1 expression in $\operatorname{Prdx} 1^{+/+}$and $\operatorname{Prdx} 1^{-/-}$primary fibroblasts. Expression of $\operatorname{Prd} x \mathrm{I}^{+/+}$ samples was normalized to 1 . * $>2$ fold-change and $\mathrm{p}<0.01$ compared to $\operatorname{Prd} x 1^{+/+}$. 


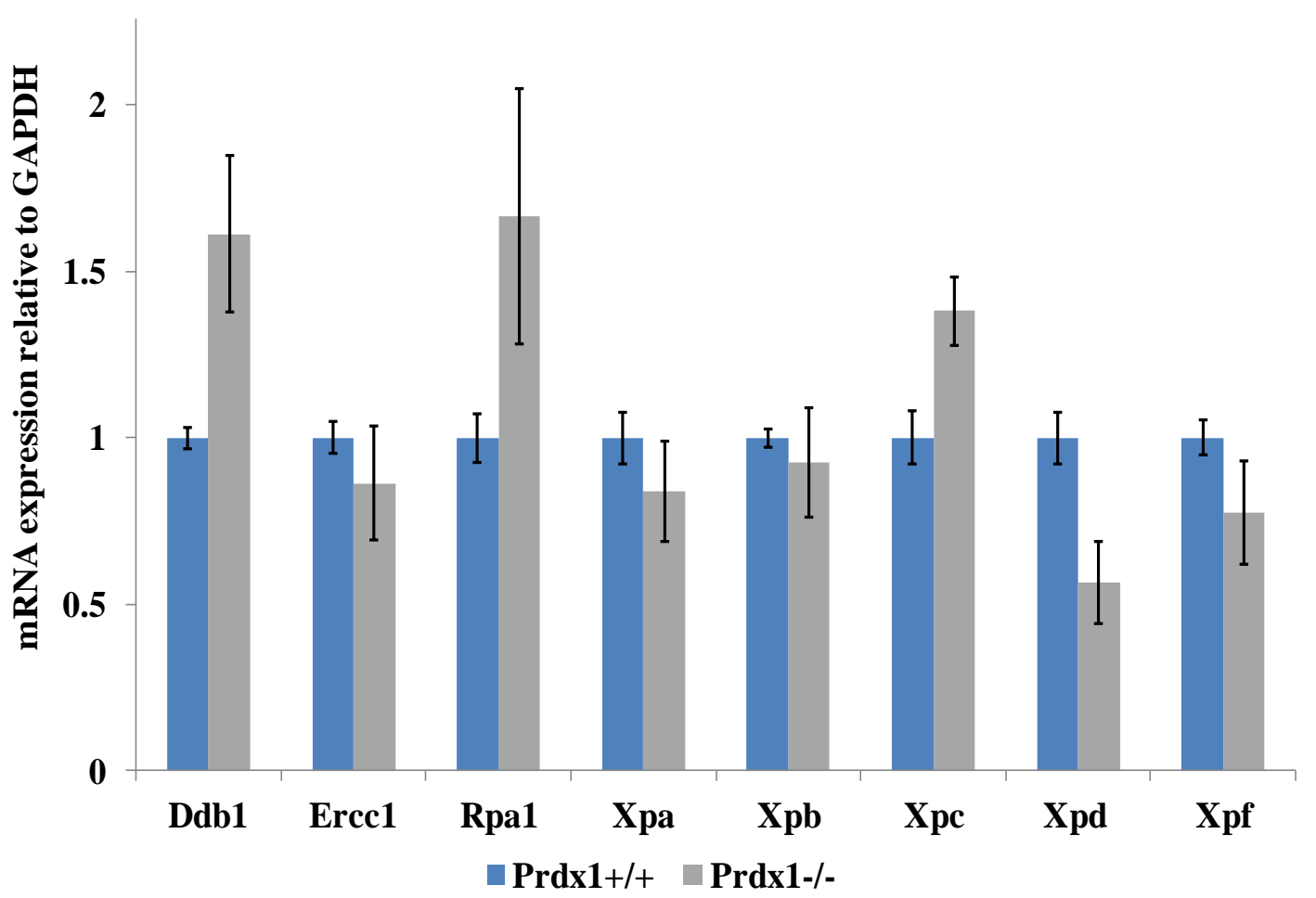

Figure 4.5. RNA expression (relative to GAPDH) of NER genes in $\operatorname{PrdxI^{+/+}}$ and $\operatorname{Pr} d x \mathrm{I}^{-/-}$ whole spleen tissue. Expression of $\operatorname{Prdx1^{+/+}}$ spleen tissue was normalized to 1.

Therefore, I measured expression of genes involved in NER as an indirect way of testing this hypothesis. Overall, majority of the genes had no significant differences in expression. However, there was a 3.8-fold decrease in Ercc1 expression in $\operatorname{Prdx} 1^{-/-} \mathrm{T}$ cells and unexpectedly, there was an equal down-regulation of Ercc1 in $\operatorname{Prdx} 1^{-/}$primary fibroblasts (Figure 4.4). In contrast to the T cell findings, the transcription of Ercc1 was unaffected in $\operatorname{Prdx1^{-/}}$ whole spleen tissue along with other genes involved in the NER pathway (Figure 4.5). 


\subsection{Discussion}

Increased incidence of DSBs and repair by homologous recombination (HR) could be promoted by deficiencies in certain DNA repair pathways. The two-fold decrease in levels of MutL homolog 1 (Mlh1) mRNA expression, a key mismatch repair (MMR) gene, in $\operatorname{Prdx} 1^{-/}$fibroblasts is significant. This is because MMR is known to suppress recombination between divergent DNA sequences to minimize inappropriate genome rearrangements as a consequence of DNA DSB repair (Harfe and JinksRobertson, 2000, Shao et al., 2004). MMR stalls strand exchange during HR in the presence of mismatches, resulting in stabilized branch intermediates (Jiricny, 2006). The down-regulation of $M l h 1$ in $\operatorname{Prd} x 1^{-/}$mice probably does not have a significant effect on MMR activity in T cells and its effect on the frequency of LOH mutations. While Mlh1 deficiency led to increased mitotic recombination (MR) in fibroblasts, it had no effect on MR in T cells (Shao et al., 2004). Instead, lack of Mlh1 led to increased point mutations, which was not observed in $\operatorname{Prd} x 1^{-/-}$mice (data not shown). Because point mutations were not increased in Prdx1 deficient T cells (Table 3), the down-regulation of Mlh1 apparently had no effect on MMR. The transcriptional down-regulation of Mlhl could be a consequence of increased methylation of the Mlh1 promoter (Herman et al., 1998; Gartel, 2006) mediated by c-Myc activation (Brenner et al., 2005; Kane et al., 1997). The cell-type specific effect of a decrease in Mlhl expression in the absence of Prdx1 illustrates the complexity of mechanisms governing tumorigenesis in different tissues. Initial transcription analysis of BER genes suggests of no significant deficiency in BER activity in $\operatorname{Prdx} 1^{-/-}$splenic T cells and in $\operatorname{Prdx} 1^{-/}$ear fibroblasts (Figure 4.2). However, there was no increase in BER gene expression that could be required to 
efficiently repair the possible increase in oxidative damage due to increased amounts of ROS observed in the $\operatorname{Prdx} 1^{-/}$cells and could lead to an increase in the number of basepair lesions. This could lead to an increased number of single strand nicks that cannot be properly filled in before the next round of DNA replication. These nicks could mature in to DSBs that would require repair by recombination and/or NHEJ. Therefore, I hypothesize that increased formation of DSBs in $\operatorname{Prdx} 1^{-/-} \mathrm{T}$ cells and ear fibroblasts that led to an increase in MR mediated LOH mutant frequency (Tables 3.1, 3.2 and 3.3) could be possibly mediated by inefficient BER activity.

Unlike the findings in $\mathrm{T}$ cells, there was a significant induction in transcription of long patch BER specific genes, Fen1, Ligase 1 and Pol $\varepsilon$ in the whole spleen tissue. Long patch BER usually occurs if there is resistance in the removal of the 5'-sugar phosphate by Pol $\beta$ after it synthesizes the first nucleotide (Matsumoto and Kim, 1995). Additional nucleotide synthesis by $\operatorname{Pol} \varepsilon$ and $\delta$ is required to displace the 5 '-sugar phosphate as part of a flap. The flap is then later cleaved by Fen1, with Ligase 1 sealing the DNA ends (Klungland and Lindahl, 1997). Long-patch repair is dependent on proliferating cell nuclear antigen (PCNA). PCNA binds to the DNA and acts as a sliding clamp protein that interacts with Fen 1, Pol $\varepsilon$, Pol $\delta$ and Ligase 1. Through such interactions, Pol $\varepsilon, \operatorname{Pol} \delta$ and Ligase 1 are speculated to be recruited by Fen 1 to the sites of DNA cleavage (Gomes XV and Burgers PM, 2000). Fen1 is known to be highly expressed in the spleen relative to other tissues (Kim IS et al., 2000). The up-regulation of Fen1, Ligase 1 and Pol $\varepsilon$ could be due to a greater need to repair oxidative DNA lesions in the Prdx1 deficient spleen caused by increased oxidative stress. This was evidenced by the increase in the transcription of catalase, glutathione peroxidase 1 
(Gpx1), Prdx2 and Prdx6 (Figure 2.4). Another possible explanation could be related to the involvement of flap-endonuclease 1 (Fen1), Ligase 1 and polymerase epsilon (Pol $\varepsilon$ ) in lagging strand DNA synthesis in DNA replication (Liu Y et al., 2004). If there is an increased expression of these genes, it would suggest increased DNA replication caused by greater proliferation of cells that comprise the Prdx1-deficient whole spleen tissue. Greater cell proliferation would also suggest greater cellular metabolism, which would generate higher amounts of ROS. The higher amounts of ROS could trigger increased expression of catalase, Gpx1, Prdx 2 and Prdx 6 possibly mediated by greater Nrf2 binding to antioxidant response element (ARE) promoter regions of those genes.

There were also other changes in DNA repair facilities attributed to the loss of Prdx1 was observed with RNA expression analyses of nucleotide excision repair (NER) genes in $\mathrm{T}$ cells and in ear fibroblasts. The loss of Prdx1 led to a significant reduction in the 5' nuclease Ercc1 mRNA expression (Figure 4.4), which suggests decreased NER activity (Langie S et al., 2007). This would lead to greater formation of helix distorting lesions, which was also previously observed in $\operatorname{Prdx} 1^{-/-}$splenocytes among other tissues (Egler RA et al., 2005). These lesions impose a strong block to elongating DNA and RNA polymerases. They also block the binding of transcription factors to their cognate recognition sequences thus hindering transcription and gene expression (Egler RA et al., 2005; Brooks PJ et al., 2000). The expression of Ercc1 is positively regulated by the AP1 transcription factor, which is comprised of c-jun and c-fos (Qi L et al., 1999). Decrease in transcription of c-jun and c-fos would lead to decrease in Ercc1 mRNA expression. However, no decrease in c-jun and c-fos RNA expression was found in either cell type with the loss of Prdx1 (data not shown). Post-translation modification through increased 
phosphorylation of c-jun at serines 63 and 73 by c-Jun N-terminal kinase/stress-activated protein kinase (JNK/SAPK) also leads to activation of Ercc1 transcription (Potapova O et al., 1997). Future studies would look in to changes in c-jun phosphorylation at serines 63 and 73 , if so, if it is mediated by JNK/SAPK signaling.

This study indicated that increased in vivo amounts of ROS may promote mutations in a cell type specific manner. This differential effect could be caused by differences in antioxidant defense and the relative robustness of the DNA repair machinery. Overall, the results suggest that the mechanism underlying the increased tumor predisposition in Prdx1-deficient mice may vary depending on tissue type. 


\section{References}

Ambs S, Bennett WP, Merriam WG, Ogunfusika MO, Oser SM, Harrington AM, Shields PG, Felley-Bosco E, Hussain SP, Harris CC, 1999. Relationship between p53 mutations and inducible nitric oxide synthase expression in human colorectal cancer. Journal of the National Cancer Institute 91: 86-88.

Babior BM, 2004. NADPH oxidase. Current Opinion in Immunology 16:42-47.

Brooks PJ, Wise DS, Berry DA, Kosmoski JV, Smerdon MJ, Somers RL, Mackie M, Spoonde AY, Ackerman EJ, Coleman E, Tarone RE, Robbins JH, 2000. The oxidative DNA lesion 8,5'-(S)-cyclo-2'-deoxyadenosine is repaired by the nucleotide excision repair pathway and blocks gene expression in mammalian cells, Journal of Biological Chemistry 275: 22355-22362.

Brenner C, Deplus R, Didelot C, Loriot A, Viré E, De Smet C, Gutierrez A, Danovi D, Bernard D, Boon T, Pelicci PG, Amati B, Kouzarides T, de Launoit Y, Di Croce L and Fuks F, 2005. Myc represses transcription through recruitment of DNA methyltransferase corepressor. EMBO Journal 24:336-346.

Busuttil RA, Garcia AM, Cabrera C, Rodriguez A, Suh Y, Kim WH, Huang TT, Vijg J, 2005 Organ-specific increase in mutation accumulation and apoptosis rate in CuZnsuperoxide dismutase-deficient mice. Cancer Research 65:11271-11275.

Cadet J, Berger M, Douki T, Ravanat JL, 1997. Oxidative damage to DNA: formation, measurement, and biological significance. Reviews of Physiology, Biochemistry and Pharmacology 131:1-87.

Cao J, Schulte J, Knight A, Leslie NR, Zagozdzon A, Bronson R, Manevich Y, Beeson C and Neumann CA, 2009. Prdx1 inhibits tumorigenesis via regulating PTEN/AKT activity. EMBO Journal 28: 1505-1517.

Cantoni O, Sestili P, Cattabeni F, Bellomo G, Pou S, Cohen M, Cerutti P, 1989. Calcium chelator quin 2 prevents hydrogen peroxide induced DNA breakage and cytotoxicity. European Journal of Biochemistry 182: 209-212.

Cho CS, Lee S, Lee GT, Woo HA, Choi E and Rhee SG, 2010. Irreversible inactivation of glutathione peroxidase 1 and reversible inactivation of peroxiredoxin 2 by $\mathrm{H}_{2} \mathrm{O}_{2}$ in red blood cells. Antioxidants \& Redox Signaling 12: 1235-1246.

Chowdhury I, Mo Y, Gao L, Kazi A, Fisher AB and Feinstein SI, 2009. Oxidant stress stimulates expression of the human peroxiredoxin 6 (Prdx6) gene by a transcriptional mechanism involving an antioxidant response element. Free Radical Biology and Medicine 46(2): 146-153.

Cooke MS, Evans MD, Dizdaroglu M, Lunec J, 2003. Oxidative DNA damage: mechanisms, mutation, and disease. FASEB Journal 17: 1195-1214. 
D'Autreaux B \& Toledano M, 2007. ROS as signalling molecules: mechanisms that generate specificity in ROS homeostasis. Nature Reviews: Molecular Cell Biology 8: 813-824.

Dahm-Daphi J, Sab C \& Alberti W, 2000. Comparison of biological effects of DNA damage induced by ionizing radiation and hydrogen peroxide in $\mathrm{CHO}$ cells. International Journal of Radiation Biology 76(1): 67-75.

de Haan JB, Bladier C, Griffiths P, Kelner M, O’Shea RD, Cheung NS, Bronson RT, Silvestro MJ, Wild S, Zheng SS, Beart PM, Hertzog PJ, and Kola I, 1998. Mice with a homozygous null mutation for the most abundant glutathione peroxidase, Gpx1, show increased susceptibility to the oxidative stress-inducing agents paraquat and hydrogen peroxide. Journal of Biological Chemistry 273(35): 22528-22536.

Dizdaroglu M, Jaruga P, Birincioglu M, Rodriguez H, 2002. Free radical-induced damage to DNA: mechanisms and measurement. Free Radical Biology and Medicine 32: 1102-1115.

Downs JA, Nussenzweig MC \& Nussenzweig A, 2007. Chromatin dynamics and the preservation of genetic information. Nature 447: 951-958.

Egler RA, Fernandes E, Rothermund K, Sereika S, de Souza-Pinto N, Jaruga P, Dizdaroglu M and Prochownik EV, 2005. Regulation of reactive oxygen species, DNA damage, and c-Myc function by peroxiredoxin 1. Oncogene 24:8038-8050.

Elchuri S, Oberley TD, Qi W, Eisenstein RS, Jackson Roberts L, Van Remmen H, Epstein CJ, Huang TT, 2005. CuZnSOD deficiency leads to persistent and widespread oxidative damage and hepatocarcinogenesis later in life. Oncogene 24:367-380.

Fearon ER \& Vogelstein B, 1990. A genetic model for colorectal tumorigenesis. Cell 61: 759-767.

Felsher DW \& Bishop JM, 1999. Transient excess of MYC activity can elicit genomic instability and tumorigenesis. Proceedings of the National Academy of Sciences 96: 3940-44.

Finkel T, 1998. Oxygen radicals and signaling. Current Opinion in Cell Biology 10: 248-253.

Fortini P \& Dogliotti E, 2007. Base damage and single-strand break repair: Mechanisms and functional significance of short- and long-patch repair subpathways. DNA Repair 6:398-409.

Frankenberg-Schwager M, Becker M, Garg I, Pralle E, Wolf H and Frankenberg D, 2008. The role of nonhomologous DNA end joining, conservative homologous recombination, and single-strand annealing in the cell cycle-dependent repair of DNA double-strand breaks induced by $\mathrm{H}_{2} \mathrm{O}_{2}$ in mammalian cells. Radiation Research 170(6): 784-793. 
Friedberg EC, Walker GC, Siede W, Wood RD, Schultz RA, Ellenberger T, 2005. DNA Repair and Mutagenesis, ASM Press, Washington, DC.

Gartel AL, 2006. A new mode of transcriptional repression by c-myc: methylation. Oncogene 2006 (25): 1989-90.

Gomes XV and Burgers PM, 2000. Two modes of FEN1 binding to PCNA regulated by DNA. EMBO Journal 19: 3811-3821.

Graves JA, Metukuri M, Scott D, Rothermund K, and Prochownik EV, 2009. Regulation of reactive oxygen species homeostasis by peroxiredoxins and c-Myc. The Journal of Biological Chemistry 284(10): 6520-6529.

Han YH, Kima HS, Kimb JM, Kimc SK, Yua DY Moona EY, 2005. Inhibitory role of peroxiredoxin II (Prx II) on cellular senescence. FEBS Letters 579: 4897-4902.

Hayakawa H, Taketomi A, Sakumi K, Kuwano M, Sekiguchi M, 1995. Generation and elimination of 8-oxo-7,8-dihydro-2'-deoxyguanosine 5'-triphosphate, a mutagenic substrate for DNA synthesis, in human cells. Biochemistry 34(1): 89-95.

Helleday T, 2003. Pathways for mitotic homologous recombination in mammalian cells. Mutation Research 532: 103-115.

Herman JG, Umar A, Polyak K, Graff JR, Ahuja N, Issa JP, Markowitz S, Willson JK, Hamilton SR, Kinzler KW, Kane MF, Kolodner RD, Vogelstein B, Kunkel TA and Baylin SB, 1998. Incidence and functional consequences of hMLH1 promoter hypermethylation in colorectal carcinoma. Proceedings of the National Academy of Sciences USA 95:6870-6875.

Ho YS, Xiong Y, Ma W, Spector A and Ho DS, 2004. Mice lacking catalase develop normally but show differential sensitivity to oxidant tissue injury. Journal of Biological Chemistry 279(31): 32804-32812.

Hoffmann ME, Mello-Filho AC and Meneghini R, 1984. Correlation between cytotoxic effect of hydrogen peroxide and the yield of DNA strand breaks in cells of different species. Biochimica et Biophysica Acta 781:234-238.

Hsu GW, Ober M, Carell T, Beese LS, 2004. Error-prone replication of oxidatively damaged DNA by a high-fidelity DNA polymerase. Nature 431: 217-221.

Huo YY, Li G, Duan RF, Guo Q, Fu CL, Hu YC, Song BQ, Yang ZH, Wu DC, Zhou PK, 2008. PTEN deletion leads to deregulation of antioxidants and increased oxidative damage in mouse embryonic fibroblasts. Free Radical Biology and Medicine 44: 15781591.

Imamura Y, Noda S, Hashizume K, Shinoda K, Yamaguchi M, Uchiyama S, Shimizu T, Mizushima Y, Shirasawa T, Tsubota K, 2006. Drusen, choroidal neovascularization, and retinal pigment epithelium dysfunction in SOD1-deficient mice: a model of age-related 
macular degeneration. Proceedings of the National Academy of Sciences USA 103: $11282-11287$.

Immenschuh S \& Baumgart-Vogt E, 2005. Peroxiredoxins, oxidative stress, and cell proliferation. Antioxidants and Redox Signaling 7: 768-777.

Itoh K, Wakabayashi N, Katoh Y, Ishii T, Kazuhiko Igarashi, Engel JD and Yamamoto M, 1999. Keap1 represses nuclear activation of antioxidant responsive elements by Nrf2 through binding to the amino-terminal Neh2 domain. Genes and Development 13:76-86.

Jaruga P \& Dizdaroglu, 2008. 8,5'-Cyclopurine-2'-deoxynucleosides in DNA:

Mechanisms of formation, measurement, repair and biological effects. DNA Repair 7: 1413-1425.

Jeggo PA, 1997. DNA-PK: at the cross-roads of biochemistry and genetics, Mutation Research 384: 1-14.

Kane MF, Loda M, Gaida GM, Lipman J, Mishra R, Goldman H, Jessup JM and Kolodner R, 1997. Methylation of the hMLH1 promoter correlates with lack of expression of hMLH1 in sporadic colon tumors and mismatch repair-defective human tumor cell lines. Cancer Research 57: 808-811.

Karanjawala ZE, Murphy N, Hinton DR, Hsieh CL, Lieber MR, 2002. Oxygen metabolism causes chromosome breaks and is associated with the neuronal apoptosis observed in DNA double-strand break repair mutants. Current Biology 12:397-402.

Keniry M and Parsons R, 2008. The role of PTEN signaling perturbations in cancer and in targeted therapy. Oncogene 27: 5477-5485.

Kim IS, Lee MY, Lee IH, Shin SL and Lee SY, 2000. Gene expression of flap endonuclease-1 during cell proliferation and differentiation. Biochimica et Biophysica Acta 1496: 333-340.

Kim HN, Morimoto Y, Tsuda T, Ootsuyama Y, Hirohashi M, Hirano T, Tanaka I, Lim Y, Yun IG, Kasai H, 2001. Changes in DNA 8-hydroxyguanine levels, 8- hydroxyguanine repair activity, and hOGG1 and hMTH1 mRNA expression in human lung alveolar epithelial cells induced by crocidolite asbestos. Carcinogenesis 22: 265-269.

Kim YJ, Ahn JY, Liang P, Ip C, Zhang Y and Park YM, 2007. Human prx1 gene is a target of Nrf2 and is up-regulated by hypoxia/reoxygenation: implication to tumor biology. Cancer Research 67: 546-554.

Klungland A and Lindahl T, 1997. Second pathway for completion of human DNA base excision-repair: reconstitution with purified proteins and requirement for DNase IV (FEN1). EMBO Journal 16: 3341-3348. 
Knudson AG, 1993. Antioncogenes and human cancer. Proceedings of the National Academy of Sciences 90: 10914-10921.

Kukreja RC et al., 1986. PGH synthase and lipoxygenase generate superoxide in the presence of NADH or NADPH. Circulation Research 59: 612-619.

Langie SAS, Knaapen M, Houbena JMJ, van Kempena FC, de Hoona JPJ, Gottschalk RWH, Godschalk RWL \& van Schooten FJ, 2007. The role of glutathione in the regulation of nucleotide excision repair during oxidative stress. Toxicology Letters 168 : 302-309.

Lebovitz RM, Zhang H, Vogel H, Cartwright J Jr, Dionne L, Lu N, Huang S, Matzuk MM, 1996. Neurodegeneration, myocardial injury, and perinatal death in mitochondrial superoxide dismutase-deficient mice. Proceedings of the National Academy of Sciences USA 93:9782-9787.

Lee JM, Calkins MJ, Chan K, Kan YW and Johnson JA, 2003. Identification of the NFE2-related factor-2-dependent genes conferring protection against oxidative stress in primary cortical astrocytes using oligonucleotide microarray analysis. Journal of Biological Chemistry 278: 12029-12038.

Lee TH, Kim SU, Yu SL, Kim SH, Park DS, Moon HB, Dho SH, Kwon KS, Kwon HJ, Han YH, Jeong S, Kang SW, Shin HS, Lee KK, Rhee SG, and Yu DY, 2003. Peroxiredoxin II is essential for sustaining life span of erythrocytes in mice. Blood 101(12): 5033-5038.

Levin DS, McKenna AE, Motycka TA, Matsumoto Y and Tomkinson AE, 2000. Interaction between PCNA and DNA ligase I is critical for joining of Okazaki fragments and long-patch base-excision repair. Current Biology 10: 919-922.

Li Q, Zhang L, Tsanga B, Gardnerc K, Bostick-Brutona F and Reeda E, 1999. Phorbol ester exposure activates an AP-1-mediated increase in ERCC-1 messenger RNA expression in human ovarian tumor cells. Cellular and Molecular Life Sciences 55: 456466.

Li Q, Tsang B, Bostick-Bruton F and Reed E, 1999. Modulation of excision repair cross complementation group 1 (Ercc-1) mRNA expression by pharmacological agents in human ovarian carcinoma cells. Biochemical Pharmacology 57: 347-353.

Lindahl T \& Barnes DE, 2000. Repair of endogenous DNA damage, Cold Spring Harbor Symposium Quantitative Biology 65: 127-133.

Liu Y, Kao H and Bambara RA, 2004. Flap Endonuclease 1: A central component of DNA metabolism. Annual Review of Biochemistry 73: 589-615. 
Luke AM, Chastainb D, Pachkowskic BD, Afoninc V, Takedad S, Kaufmana DG, Swenberga DA and Nakamurac J, 2010. Accumulation of true single strand breaks and AP sites in base excision repair deficient cells. Mutation Research 694: 65-71.

Marietta C, Gulam H, Brooks PJ, 2002. A single 8,5'-cyclo-2'-deoxyadenosine lesion in a TATA box prevents binding of the TATA binding protein and strongly reduces transcription in vivo. DNA Repair (Amsterdam) 1: 967-975.

Matsumoto Y and Kim K, 1995. Excision of deoxyribose phosphate residues by DNA polymerase $\beta$ during DNA repair. Science 269: 699-702.

Meyer F, Fiala E, Westendorf J, 2000. Induction of 8-oxodGTPase activity in human lymphoid cells and normal fibroblasts by oxidative stress. Toxicology 146: 83-92.

Miaskiewicz K, Miller JH, Fuciarelli AF, 1995. Theoretical analysis of DNA intrastrand cross linking by formation of 8,5'-cyclodeoxyadenosine, Nucleic Acids Research 23: 515-521.

Mu ZM, Yin XY, and Prochownik EV, 2002. Pag, a putative tumor suppressor, interacts with the Myc box II domain of c-Myc and selectively alters its biological function and target gene expression. Journal of Biological Chemistry 277(45): 43175-43184.

Muller FL, Song W, Liu Y, Chaudhuri A, Pieke-Dahl S, Strong R, Huang TT, Epstein CJ, Roberts LJ 2nd, Csete M, Faulkner JA, Van Remmen H, 2006. Absence of CuZn superoxide dismutase leads to elevated oxidative stress and acceleration of age-dependent skeletal muscle atrophy. Free Radical Biology and Medicine 40:1993-2004.

Neumann CA, Krause DS, Carman CV, Das S, Dubey DP, Abraham JL, Bronson RT, Fujiwara Y, Orkin SH \& Van Etten RA, 2003. Essential role for the peroxiredoxin Prdx1 in erythrocyte antioxidant defence and tumour suppression. Nature 424: 561-565.

Pascucci B, D’Errico M, Parlanti E, Giovannini S, and Dogliotti E, 2011. Role of nucleotide excision repair proteins in oxidative DNA damage repair: an updating. Biochemistry (Moscow): 76(1): 4-15.

Pastor $\mathrm{N}$ et al., 2000. A detailed interpretation of $\mathrm{OH}$ radical footprints in a TBPDNA complex reveals the role of dynamics in the mechanism of sequence specific binding. Journal of Molecular Biology 304: 55-68.

Podlutsky AJ, Dianova II, Podust VN, Bohr VA, Dianov GL, 2001. Human DNA polymerase $\beta$ initiates DNA synthesis during long-patch repair of reduced AP sites in DNA. EMBO Journal 20: 1477-1482.

Potapova O, Haghighi A, Bost F, Liu C, Birrer MJ, Gjerset R \& Mercola D, 1997. The Jun kinase/stress-activated protein kinase pathway functions to regulate DNA repair and 
inhibition of the pathway sensitizes tumor cells to cisplatin. Journal of Biological Chemistry 272(22): 14041-14044.

Prise KM, Davies S and Michael BD, 1989. Cell killing and DNA damage in Chinese hamster V79 cells treated with hydrogen peroxide. International Journal of Radiation Biology 55: 583-592.

Reddy VN, Kasahara E, Hiraoka M, Lin LR, Ho YS, 2004. Effects of variation in superoxide dismutases (SOD) on oxidative stress and apoptosis in lens epithelium. Experimental Eye Research 79:859-868.

Rhee SG, 2003. Cellular regulation by hydrogen peroxide. Journal of the American Society of Nephrology 14:S211-215.

Shao C, Deng L, Chen Y, Kucherlapati R, Stambrook PJ and Tischfield JA, 2004. Mlh1 mediates tissue-specific regulation of mitotic recombination. Oncogene 23: 9017-9024.

Shen WH, Balajee AS, Wang J, Wu H, Eng C, Pandolfi PP, and Yin Y, 2007. Essential role for nuclear PTEN in maintaining chromosomal integrity. Cell 128: 157-170.

Sies H. 1985. Oxidative stress: introductory remarks. In Oxidative Stress, ed. H Sies. Academic Inc. (Inserts 1, 2).

Sonntag V (1987). The Chemical Basis of Radiation Biology, Taylor and Francis, New York

Stambolic V, Suzuki A, de la Pompa JL, Brothers GM, Mirtsos C, Sasaki T, Ruland J, Penninger JM, Siderovski DP and Mak TW,1998. Negative regulation of PKB/AKTdependent cell survival by the tumor suppressor PTEN. Cell 95: 29-39.

Thannickal VJ \& Fanburg BL, 2000. Reactive oxygen species in cell signaling. American Journal of Physiology: Lung Cell and Molecular Physiology 279: L1005L1028.

Tom S, Henricksen LA, Bambara RA, 2000. Mechanism whereby proliferating cell nuclear antigen stimulates flap endonuclease 1. Journal of Biological Chemistry 275: 10498-10505.

Tsan MF, White JE, Caska B, Epstein CJ, Lee CY, 1998. Susceptibility of heterozygous MnSOD gene-knockout mice to oxygen toxicity. American Journal of Respiratory Cellular and Molecular Biology 19:114-120.

Vafa O, Wade M, Kern S, Beeche M, Pandita TK, Hampton GM, and Wahl GM, 2002. c-Myc can induce DNA damage, increase reactive oxygen species, and mitigate p53 function: A mechanism for oncogene-induced genetic instability. Molecular Cell 9:10311044. 
Valko $\mathrm{M}$ et al., 2007. Free radicals and antioxidants in normal physiological functions and human disease. The International Journal of Biochemistry and Cell Biology 39: 4484.

van Loon B, Markkanen E and Hübscher E, 2010. Oxygen as a friend and enemy: How to combat the mutational potential of 8-oxo-guanine. DNA Repair 9: 604-616.

Van Remmen H, Salvador C, Yang H, Huang TT, Epstein CJ, Richardson A, 1999. Characterization of the antioxidant status of the heterozygous manganese superoxide dismutase knockout mouse. Archives in Biochemistry and Biophysics 363:91-97.

Van Remmen H, Ikeno Y, Hamilton M, Pahlavani M, Wolf N, Thorpe SR, Alderson NL, Baynes JW, Epstein CJ, Huang TT, Nelson J, Strong R, Richardson A, 2003. Life-long reduction in MnSOD activity results in increased DNA damage and higher incidence of cancer but does not accelerate aging. Physiological Genomics 16:29-37.

Van Remmen H, Qi W, Sabia M, Freeman G, Estlack L, Yang H, Mao Guo Z, Huang TT, Strong R, Lee S, Epstein CJ, Richardson A, 2004. Multiple deficiencies in antioxidant enzymes in mice result in a compound increase in sensitivity to oxidative stress. Free Radical Biology and Medicine 36:1625-1634.

Veal EA et al., 2007. Hydrogen peroxide sensing and signaling. Molecular Cell 26: 114.

Walker JR, Corpina RA, Goldberg J, 2001. Structure of the Ku heterodimer bound to DNA and its implications for double-strand break repair, Nature 412: 607-614.

Wang X, Phelan SA, Semb KF, Taylor EF, Petros C, Brown A, Lerner CP, and Paigen B, 2003. Mice with targeted mutation of peroxiredoxin 6 develop normally but are susceptible to oxidative stress. Journal of Biological Chemistry 278(27): 25179-25190.

Ward JF, Blakely WF and Joner EI, 1985. Mammalian cells are not killed by DNA single-strand breaks caused by hydroxyl radicals from hydrogen peroxide. Radiation Research 103: 383-392.

Wagner E et al., 2002. A method for detection of overoxidation of cysteine: peroxiredoxins are oxidised in vivo at the active site cysteine during oxidative stress. Biochemical Journal 366: 777-785.

Wijnhoven SWP, Kool HJM, van Teijlingen CMM, van Zeeland AA, Vrieling H, 2001. Loss of heterozygosity in somatic cells of the mouse: An important step in cancer initiation? Mutation Research 473:23-36.

Wood ZA et al., 2003. Structure, mechanism and regulation of peroxiredoxins. TRENDS in Biochemical Sciences 28(1): 32-40. 
Yang KS, Kang SW, Woo HA, Hwang SC, Chae HZ, Kim K and Rhee SG, 2002. Inactivation of human peroxiredoxin I during catalysis as the result of the oxidation of the catalytic site cysteine to cysteine-sulfinic acid. Journal of Biological Chemistry 277: 38029-38036.

Yoshizumi M et al., 2001. Signal transduction of reactive oxygen species and mitogenactivated protein kinases in cardiovascular disease. The Journal of Medical Investigation 48: 11-24.

Yuan L, Inoue S, Saito Y and Nakajima O, 1993. An evaluation of the effects of cytokines on intracellular oxidative production in normal neutrophils by flow cytometry. Experimental Cell Research 209: 375-381. 


\section{LIST OF ABBREVIATIONS}

8-oxoG

8-oxoGTPs

Apex

Aprt

ARE

$\beta-\mathrm{ME}$

BER

BSA

C-Myc

cDNA

CFE

CL

CL-D

ConA

CM-H ${ }_{2}$ DCFDA

CuZNSOD (Sod1)

DAP

Ddb1

DMEM

DMSO

dNTPs

DSBs

EcSOD

Ercc1

FBS

Fen1

GAPDH

GC

GGR

$\mathrm{Gpx}$

$\mathrm{H}_{2} \mathrm{O}_{2}$

HEPES

Hprt

HR

ID

IL-2

JNK/SAPK

Lig1

Lig3

LOH

MEFs

MEM NEAA

Mlh1

MMR 8-oxoguanine

8-oxoguanine triphosphates

apurinic-apyrimidinic endonuclease

adenine phosphoribosyltransferase

antioxidant response element

beta-mercaptoethanol

base excision repair

bovine serum albumin

c- myelocytomatosis

complementary DNA

colony forming efficiency

chromosome loss

chromosome loss-duplication

concanavalin A

chloromethyl dihydrodichlorofluorescein diacetate

copper-zinc superoxide dismutase

2,6- diaminopurine

damage-specific DNA binding protein 1

Dulbecco's modified eagle medium

dimethyl sulfoxide

deoxynucleotide triphosphates

double strand breaks

extracellular superoxide dismutase

excision repair cross-complementing rodent repair deficiency

complementation group 1

fetal bovine serum

flap endonuclease 1

glyceraldehyde-3-phosphate dehydrogenase

gene conversion

global genome repair

glutathione peroxidase

hydrogen peroxide

4-(2-hydroxyethyl)-1-piperazineethanesulfonic acid

hypoxanthine phosphoribosyltransferase

homologous recombination

interstitial deletion

interleukin 2

jun/stress-activated protein kinase

ligase 1

ligase 3

loss of heterozygosity

mouse embryonic fibroblasts

minimum essential medium with non-essential amino acids

MutL homolog 1, colon cancer, nonpolyposis type 2

mismatch repair 


$\begin{array}{ll}\text { MnSOD } & \text { manganese superoxide dismutase } \\ \text { MR } & \text { mitotic recombination } \\ \text { Mre11 } & \text { meiotic recombination 11 homolog } \\ \text { MSM } & \text { microsatellite markers } \\ \text { Neil1 } & \text { nei endonuclease VIII-like 1 } \\ \text { Nbs1 } & \text { nibrin } \\ \text { NER } & \text { nucleotide excision repair } \\ \text { NHEJ } & \text { non homologous end joining } \\ \text { NO } & \text { nitric oxide } \\ \text { Nudt1 } & \text { nucleoside diphosphate-linked moiety X motif 1 } \\ \text { Ogg1 } & \text { 8-oxoguanine DNA glycosylase } \\ \text { OH• } & \text { hydroxyl radicals } \\ \text { ONOO- } & \text { peroxynitrite radicals } \\ \text { PBS } & \text { phosphate buffered saline } \\ \text { PCNA } & \text { proliferative cell nuclear antigen } \\ \text { PCR } & \text { polymerase chain reaction } \\ \text { Pol } 3 & \text { polymerase beta } \\ \text { Pole } & \text { polymerase epsilon } \\ \text { Pol } \delta & \text { polymerase gamma } \\ \text { Prdx } & \text { peroxiredoxin } \\ \text { Pten } & \text { phosphatase and tensin homolog } \\ \text { qPCR } & \text { quantitative real-time polymerase chain reaction } \\ \text { Rb } & \text { retinoblastoma } \\ \text { ROS } & \text { reactive oxygen species } \\ \text { Rpa } & \text { replication protein a } \\ \text { SSBs } & \text { single strand breaks } \\ \text { TCR } & \text { transcription coupled repair } \\ \text { Tg } & \text { thymine glycol } \\ \text { Ung } & \text { uracil-DNA glycosylase } \\ \text { Xpa } & \text { xeroderma pigmentosum a } \\ \text { Xpb } & \text { xeroderma pigmentosum b } \\ \text { Xpc } & \text { xeroderma pigmentosum c } \\ \text { Xpd } & \text { xeroderma pigmentosum d } \\ \text { Xpf } & \text { xeroderma pigmentosum f } \\ \text { Xpg } & \text { xeroderma pigmentosum g } \\ \text { Xrcc1 } & \text { DNA ligase III-x-ray repair cross-complementing 1 } \\ & \\ & \end{array}$




\title{
Curriculum Vitae
}

\author{
Vamsi Rani
}

\section{EDUCATION}

Ph.D. in Microbiology and Molecular Genetics, Rutgers University, 2005-2012

M.S. in Biomedical Engineering, Carnegie Mellon University, 2002-2004

B.S. in Biomedical Engineering, Rutgers University, 1998-2002

\section{RESEARCH EXPERIENCE}

Graduate Assistant, Rutgers University, September 2005-May 2012

Student Researcher, Carnegie Mellon University, September 2002-May 2004

\section{PUBLICATIONS}

Rani V, Neumann C, Shao C and Tischfield J. "Prdx 1 deficiency in mice promotes tissue specific loss of heterozygosity mediated by deficiency in DNA repair and increased oxidative stress" Mutation Research-Fundamental and Molecular Mechanisms of Mutagenesis (Accepted) 